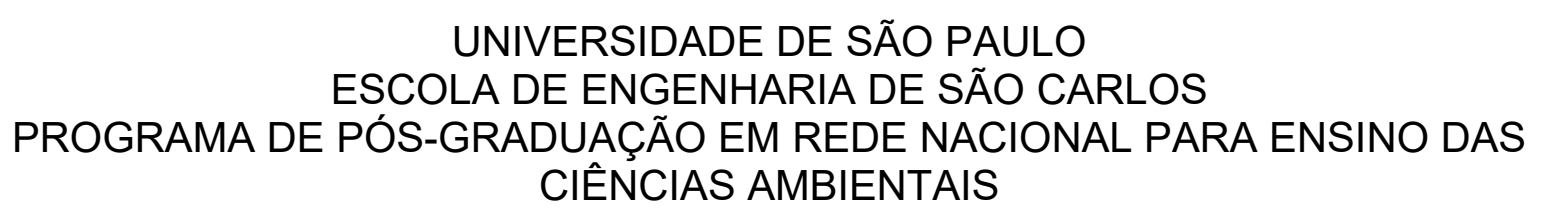

WILSON ANTONIO LOPES DE MOURA

A CONSTRUÇÃO DE INDICADORES DE DESENVOLVIMENTO SUSTENTÁVEL A PARTIR DA ANÁLISE DO ENTORNO ESCOLAR 



\author{
UNIVERSIDADE DE SÃO PAULO \\ ESCOLA DE ENGENHARIA DE SÃO CARLOS \\ PROGRAMA DE PÓS-GRADUAÇÃO EM REDE NACIONAL PARA ENSINO DAS \\ CIÊNCIAS AMBIENTAIS
}

\title{
A CONSTRUÇÃO DE INDICADORES DE DESENVOLVIMENTO SUSTENTÁVEL A PARTIR DA ANÁLISE DO ENTORNO ESCOLAR
}

Wilson Antonio Lopes de Moura

Orientador: Prof. Dr. Luiz Antonio Daniel

Dissertação apresentada ao Programa de PósGraduação em Rede Nacional para Ensino das Ciências Ambientais, da Escola de Engenharia de São Carlos- EESC-USP, como parte dos requisitos para obtenção do título de Mestre em Ciências - Área de concentração: Ensino das Ciências Ambientais.

VERSÃO CORRIGIDA

A VERSÃO ORIGINAL ESTÁ DISPONÍVEL NO PROGRAMA ALOJADO PELA EESC

SÃO CARLOS

2019 


\section{AUTORIZO A REPRODUÇÃO TOTAL OU PARCIAL DESTE TRABALHO, POR QUALQUER MEIO C'ONVENCIONAL OU ELETRÔNICO, PARA FINS DE ESTUDO E PESQUISA, DESDE QUE CITADA A FONTE.}

Ficha catalográfica elaborada pela Biblioteca Prof. Dr. Sérgio Rodrigues Fontes da EESC/USP com os dados inseridos pelo(a) autor(a).
A931a A CONSTRUÇÃO DE INDICADORES DE DESENVOLVIMENTO SUSTENTÁVEL A PARTIR DA ANÁLISE DO ENTORNO ESCOLAR / Wilson Antonio Lopes de Moura; orientador Luiz Antonio Daniel. São Carlos, 2019.

Dissertação (Mestrado) - Programa de Pós-Graduação em Rede Nacional para Ensino das Ciências Ambientais e Área de Concentração em Ensino das Ciências Ambientais -- Escola de Engenharia de São Carlos da Universidade de São Paulo, 2019.

1. Ensino das Ciências Ambientais. 2. Indicadores de Desenvolvimento Sustentável. 3. Educação Básica. I. Título.

Eduardo Graziosi Silva - CRB - 8/8907 


\section{FOLHA DE JULGAMENTO}

Candidato: Licenciado WILSON ANTONIO LOPES DE MOURA.

Tífulo da dissertação: "A construção de indicadores de desenvolvimento sustentável a partir da análise do entorno escolar".

Data da defesa: 19/06/2019.

\section{Comissão Julgadora:}

Prof. Dr. Luiz Antonio Daniel (Orientador)

(Escola de Engenharia de São Carlos/EESC)

Profa. Dra. Kátia Vlana Cavalcante

(Universidade Federal do Amazonas/UFAM)

Prof. Dr. Otacílio Antunes Santana

(Universidade Federal de Pernambuco/UFPE)
Resultado:

Aprovidos
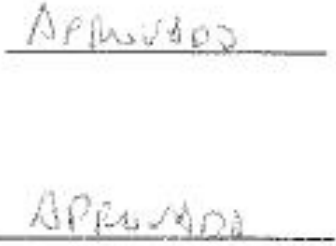

Coordenador do Programa de Pós-Graduaçāo em Rede Nacional para Ensino das Ciências Ambientais:

Prof. Associado Tadeu Fabrício Malheiros

Presidente da Comissão de Pós-Graduação:

Prof. Titular Murilo Araujo Romero 
A mulher que me inspira todos os dias desta longa caminhada, minha esposa e companheira Samara Ao meu anjo, que me faz sempre querer ser e fazer melhor, minha querida filha 


\section{AGRADECIMENTOS}

O caminho apesar de curto, é complexo e cheio de aprendizagens. Durante esta caminhada algumas pessoas e instituições que muito me auxiliaram e proporcionaram momentos de grande reflexão merecem agradecimento.

Primeiramente gostaria de agradecer o meu orientador Professor Doutor Dr. Luiz Antonio Daniel, que ao aceitar essa árdua tarefa não economizou esforços e, sem dúvida, foi responsável por realizar um sonho não só meu, mas de toda minha família, mais ainda, trabalhou para que a educação pública de nosso país possa ter cada dia mais qualidade em seu ensino.

Duas pessoas em especial também merecem meus agradecimentos, a minha esposa Samara por sempre acreditar, incentivar e partilhar desta importante caminhada. Entendo que nada disso seria possível sem que em nossa relação houvesse uma constante vontade em ver o crescimento e a felicidade no outro, fazendo mais do que isso, criando condições para que tudo se concretizasse. A minha filha Lara por me fazer entender o real objetivo dessa vida. Se sonho com uma educação pública melhor, o faço pensando nela, pois sei que merece tudo de melhor nesta vida, sempre.

Aos (s) professores (as) do Programa de Pós-Graduação em Rede Nacional para Ensino das Ciências Ambientais que muito contribuíram para minha formação durante esse período e que serão lembrados em minhas práticas na sala de aula, ensinamentos esses que carregam um grande valor para a construção de uma sociedade mais justa.

Aos alunos e gestores da Escola Municipal de Educação Básica Professor Erotides de Campos, por acreditar e construir comigo este trabalho, sendo desenvolvido nestes dois últimos anos.

Por fim, como dizia Paulo Freire, a educação não transforma o mundo, a educação muda as pessoas. Pessoas transformam o mundo. Sei que os tempos são difíceis, mas acredito fortemente que a educação pode transformar pessoas e que elas, com certeza, poderão contribuir para um mundo cada vez melhor. 
"Enquanto eles capitalizam a realidade, Eu, socializo meus sonhos" 


\section{RESUMO}

MOURA, W. A. L. A construção de Indicadores de Desenvolvimento Sustentável a partir da análise do entorno escolar. 2019. 136 p. Dissertação (Mestrado em Ensino das Ciências Ambientais) - Escola de Engenharia de São Carlos, Universidade de São Paulo, São Carlos, 2019.

Diversos são os problemas ambientais presentes na sociedade, sendo que o ambiente escolar se torna um local de grande importância para levar as discussões referentes a eles e ajudar na busca por possíveis respostas a esses desafios. $O$ presente trabalho tem por objetivo discutir a construção de Indicadores de Desenvolvimento Sustentável a partir da análise do entorno escolar, se utilizando de diferentes recursos didáticos e do Modelo PEIR. Além disso, teve como foco a produção de uma cartilha contendo um guia sobre como construir indicadores, podendo ser utilizada por professores e alunos em suas aulas. A metodologia a ser aplicada é a de Pesquisa Ação e apresenta inicialmente um estudo bibliográfico sobre quatro temas que são estruturantes na pesquisa, sendo eles: os recursos didáticos, as Ciências Ambientais, o Modelo PEIR e os Indicadores de Desenvolvimento Sustentável. Foram utilizadas durante o desenvolvimento da pesquisa aulas de campo, mapas e imagens de satélite para construir junto aos alunos os indicadores. Como resultados obtidos pode-se dizer que a utilização do Modelo PEIR e dos Indicadores de Desenvolvimento Sustentável para o desenvolvimento de aprendizagens relativas às questões ambientais presentes no entorno escolar são de grande importância para que o aluno consiga associar elementos presentes nas diferentes dimensões, integrando questões sociais, históricas, econômicas, culturais e ambientais. Esse uso do Modelo PEIR e dos Indicadores deve ser acompanhado de práticas pedagógicas que se utilizem de diferentes recursos didáticos para seu desenvolvimento, sendo principalmente as aulas de campo um dos recursos de maior impacto para sua compreensão por parte dos alunos, levando a uma educação ambiental crítica e reflexiva, desenvolvendo alunos engajados na análise e transformação dos espaços ambientais locais.

Palavras-chave: Ensino das Ciências Ambientais. Indicadores de Desenvolvimento Sustentável. Educação Básica. 


\section{ABSTRACT}

MOURA, W. A. L. The construction of Sustainable Development Indicators from the analysis of the school environment. 2019. 136 p. Master's Dissertation (Master in Environmental Science Teaching) - School of Engineering of São Carlos, University of São Paulo, São Carlos, 2019.

There are several environmental problems present in our society, and the school environment becomes a place of great importance to carry out discussions about them and help in the search for possible answers to these challenges. The objective of the present work is to discuss the construction of Sustainable Development Indicators from the analysis of the school environment, using different didactic resources and the PEIR Model. In addition, it focused on the production of a booklet containing a guide on how to construct indicators, which can be used by teachers and students in their classes. The methodology to be applied is Action Research and initially presents a bibliographic study on four themes that are structuring in the research, being: didactic resources, Environmental Sciences, the PEIR Model and the Indicators of Sustainable Development. Field lessons, maps and satellite images were used during the development of the research to build the indicators together with the students. As results we can say that the use of the Model PEIR and the Indicators of Sustainable Development for the development of learning related to the environmental issues present in the school environment are of great importance for the student to be able to associate elements present in the different dimensions, integrating social, historical, economic, cultural and environmental. This use of the PEIR Model and the Indicators must be accompanied by pedagogical practices that use different didactic resources for its development, being mainly the field lessons one of the resources of greater impact for its understanding on the part of the students, leading to an environmental education critical and reflexive, developing students engaged in the analysis and transformation of local environmental spaces.

Keywords: Environmental Science Teaching. Sustainable Development Indicators. Basic Education. 


\section{LISTA DE SIGLAS}

DS- Desenvolvimento Sustentável

EMEB- Escola Municipal de Educação Básica

IBAMA- Instituto Brasileiro do Meio Ambiente e dos Recursos Naturais

IBGE- Instituto Brasileiro de Geografia e Estatística

MMA- Ministério do Meio Ambiente

OCDE- Organização para a Cooperação e Desenvolvimento Econômico

PEIR- Pressão, Estado, Impacto e Resposta

PNIA- Painel Nacional de Indicadores Ambientais

PNUMA- Programa das Nações Unidas para o Meio Ambiente 


\section{LISTA DE FIGURAS}

Figura 1: Contagem do número de trabalhos encontrados segundo as bases de

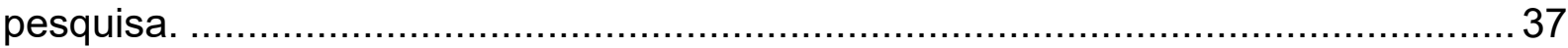

Figura 2: Contagem do número de trabalhos selecionados segundo as bases de

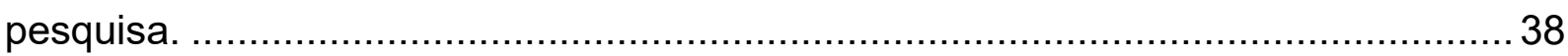

Figura 3: Representação das etapas de execução da pesquisa ...............................4 43

Figura 4: Aula de campo realizada no entorno escolar ..........................................51

Figura 5: Anotações dos dados encontrados pelos alunos em uma folha de controle. 51

Figura 6: Rio Paraisolândia próximo ao entorno escolar. 51

Figura 7: Construção da imagem de satélite com os dados obtidos na aula de campo.

Figura 8: Inserção das legendas na imagem de satélite sobre o bairro. 52

Figura 9: Imagem de satélite apresentação aos demais alunos, professores, gestores e pais/responsáveis. 53

Figura 10: Produção do local de armazenamento dos indicadores do kit de análise da água. 53

Figura 11: Produção do local de armazenamento das amostras do kit de análise da água. 54

Figura 12: Kit para análise da água. 54

Figura 13: Alunos coletando água para ser analisada com o kit. 55

Figura 14: Alunos realizando a análise da água com o kit. 55

Figura 15: Kit para análise da água produzido pelos alunos. 74

Figura 16: Manual de instruções sobre o uso do kit de análise da água. 75

Figura 17: Escala para análise por comparação da água. 76

Figura 18: Folha para preenchimento dos alunos com os dados obtidos durante a análise da água. 


\section{LISTA DE QUADROS}

Quadro 1: Exemplo do Modelo PEIR criado pelos alunos durante as atividades. .....56

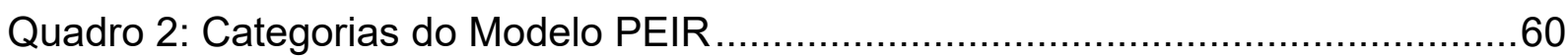

Quadro 3: Capítulos e temas abordados no produto ............................................65 


\section{SUMÁRIO}

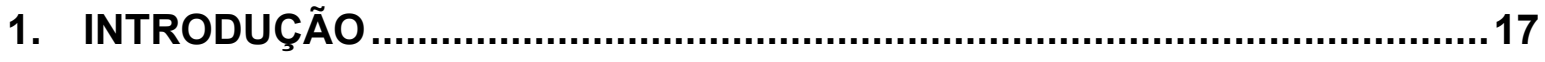

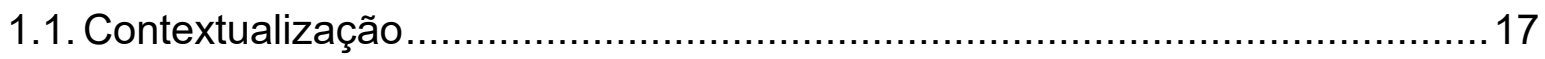

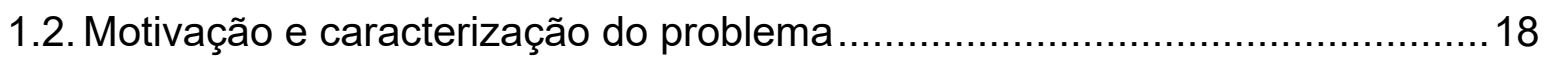

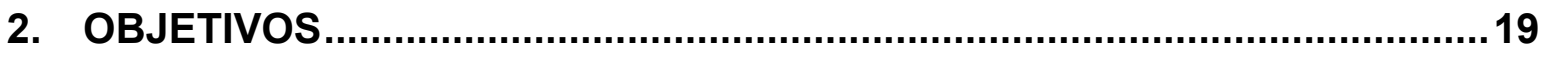

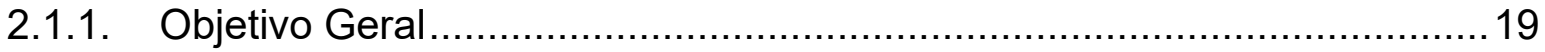

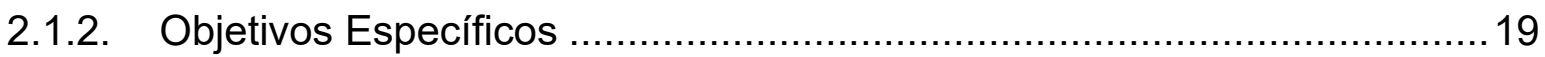

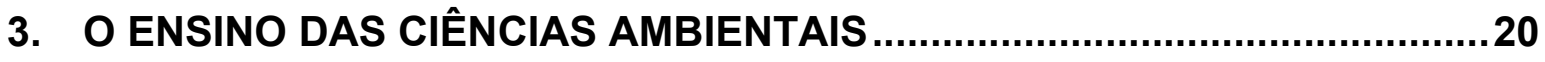

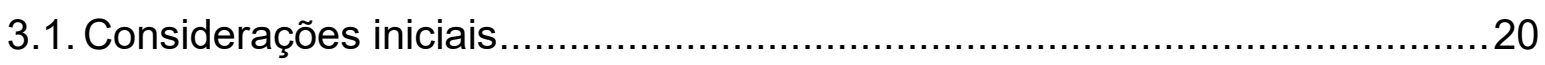

3.2. As Ciências Ambientais e a Educação Ambiental .......................................20

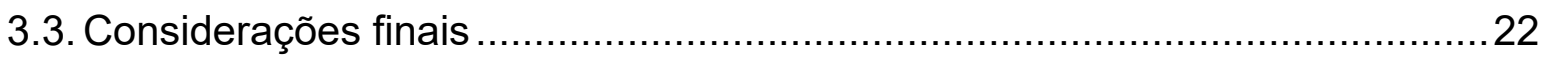

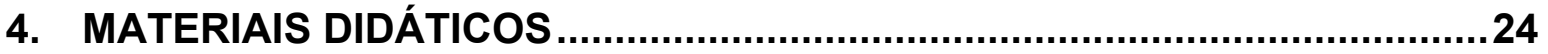

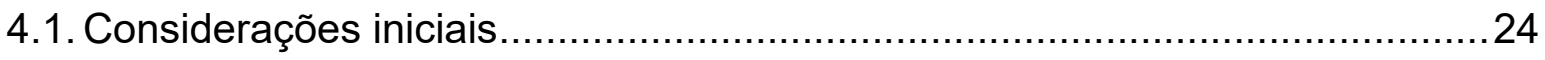

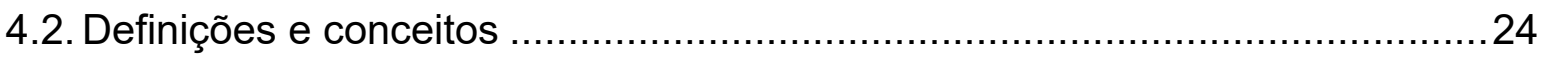

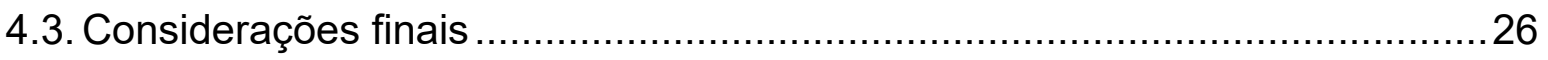

5. INDICADORES DE DESENVOLVIMENTO SUSTENTÁVEL ........................27

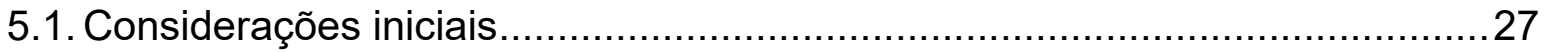

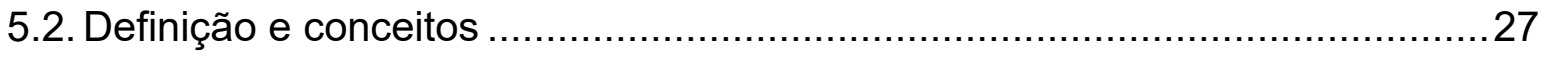

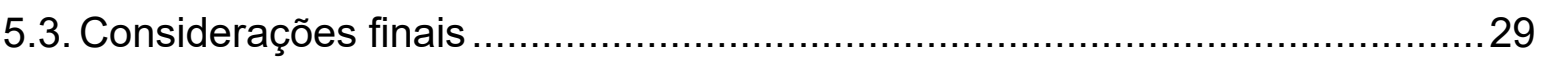

6. MODELOS DE ANÁLISE DOS INDICADORES DE

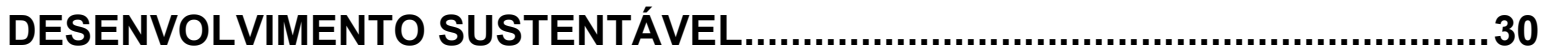

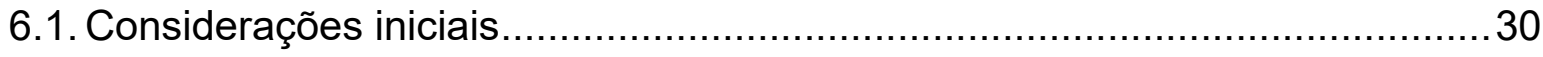

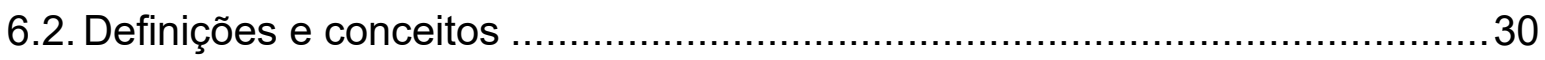

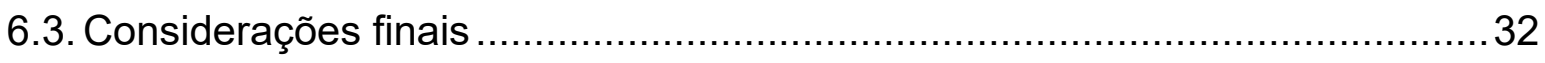

7. A CONSTRUÇÃO DE MATERIAIS DIDÁTICOS PARA O ENSINO DAS CIÊNCIAS AMBIENTAIS: UMA REVISÃO SISTEMÁTICA .................................33

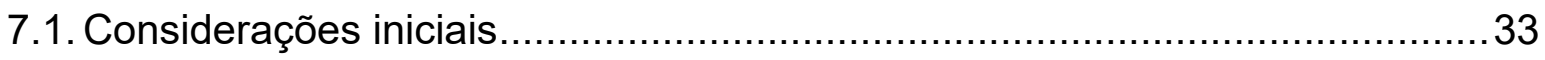

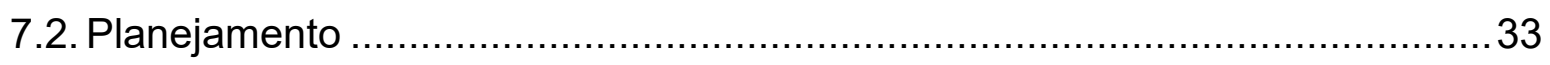

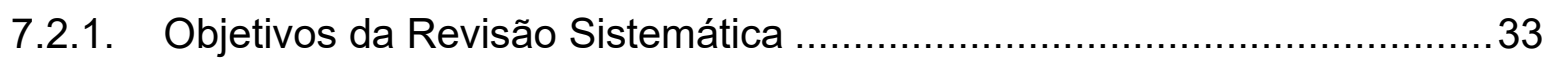

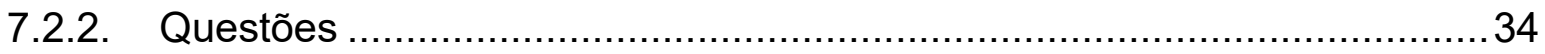

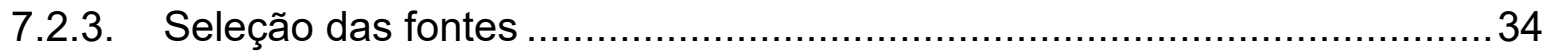

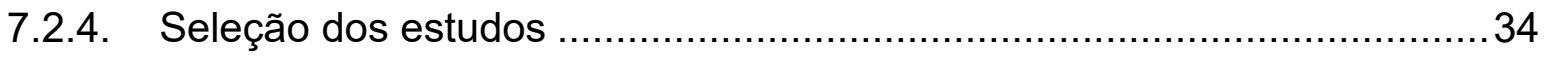




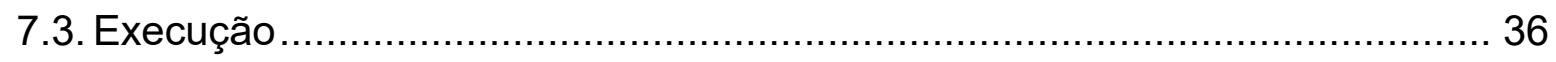

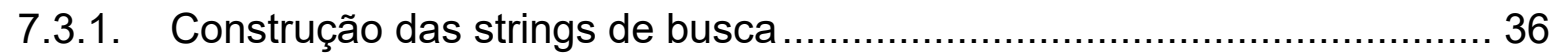

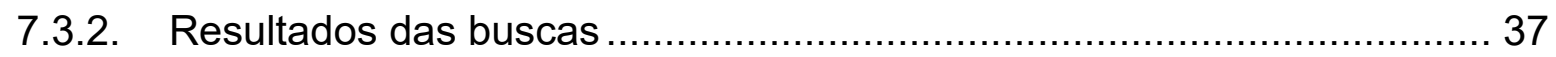

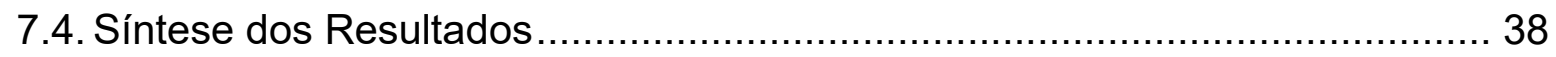

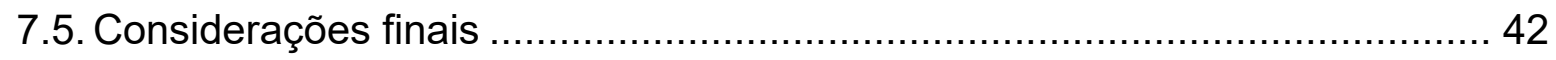

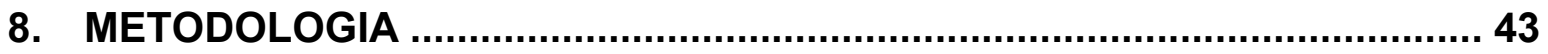

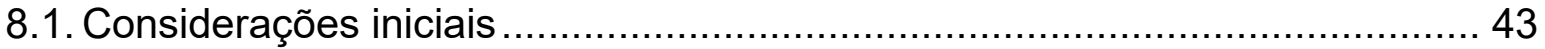

8.2. Procedimentos metodológicos.............................................................. 43

8.2.1. Produção da imagem de satélite com os elementos encontrados no

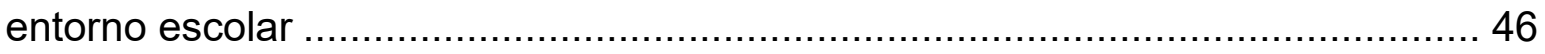

8.2.2. Produção do Kit de Análise da Água...................................................... 47

8.2.3. Aplicação do Modelo PEIR ……………................................... 48

8.2.4. Construção dos Indicadores de Desenvolvimento Sustentável ............... 48

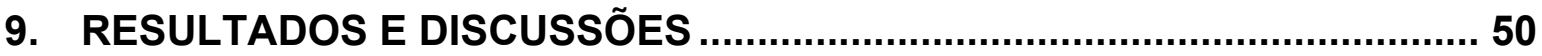

9.1. O processo de construção das aulas e do kit de análise da água.................. 50

9.2. Análise dos dados obtidos durante a pesquisa ........................................ 57

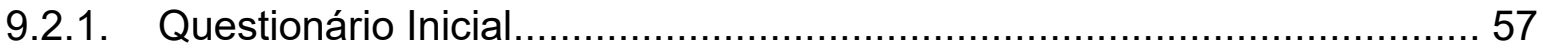

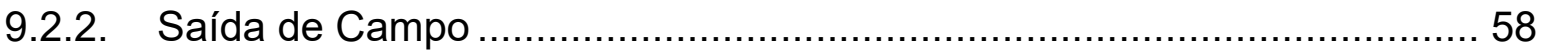

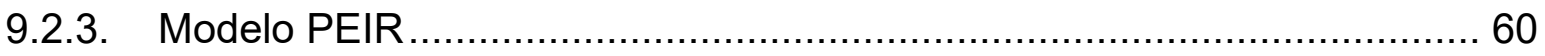

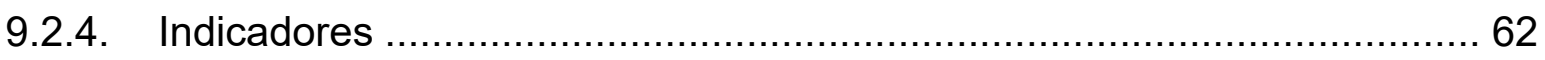

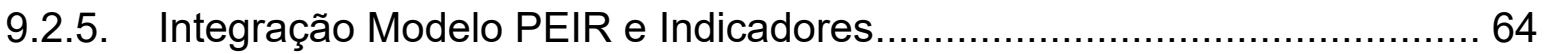

9.3. A construção do produto: A cartilha como guia para a análise do entorno

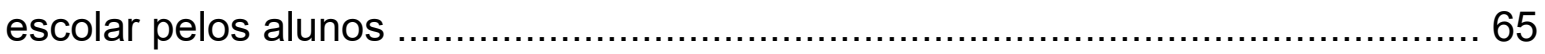

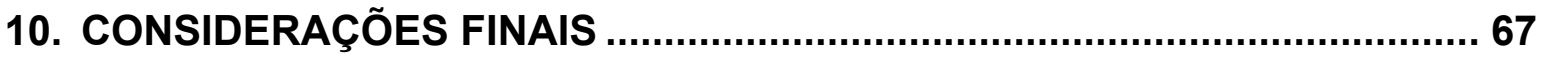

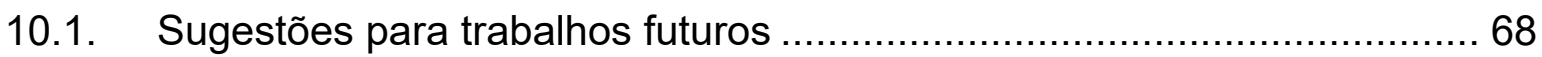

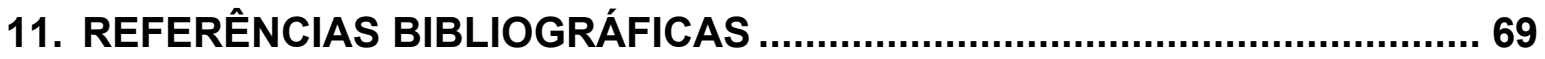

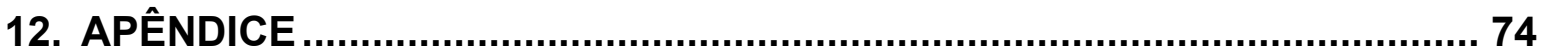

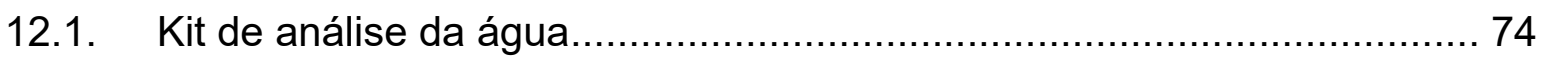

12.2. Termo de Consentimento Livre e Esclarecido .................................... 78

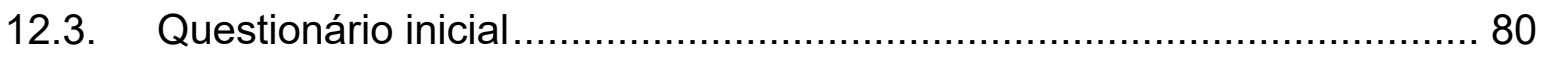

12.4. Transcrição da Entrevista realizada após a Saída de Campo ................. 82

12.5. Transcrição da Entrevista realizada após o fim das aulas realizadas ...... 84

12.6. Modelo PEIR produzido pelos alunos ............................................. 85 
12.7. Indicadores de Desenvolvimento Sustentável produzido pelos alunos ....89

12.8. Produto: Analisando o entorno escolar: um guia para construção de

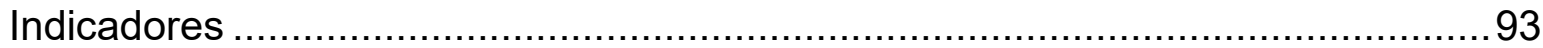




\section{INTRODUÇÃO}

\subsection{Contextualização}

O antropocentrismo tem levado nossas sociedades ao limite das suas relações com os diferentes ecossistemas. As transformações presenciadas nas últimas décadas demostraram que são necessárias reflexões sobre como o ser humano se integra e interage com os demais seres presentes no planeta. Como consequência disso é preciso despertar em cada pessoa o sentimento de "pertencimento", responsabilidade e participação na busca de soluções que o tema do desenvolvimento sustentável propõe (SORRENTINO, 2011)

No ambiente escolar a construção de práticas pedagógicas reflexivas se torna fundamental para a efetivação dessas mudanças. A busca constante pela alfabetização ambiental leva a aprender como viver de forma mais sustentável, desenvolvendo o respeito a todas as formas de vida. Dessa forma é importante que a educação ambiental seja aplicada de forma interdisciplinar, pois é vista como uma forma de renovar as atitudes diante de problemas existentes na sociedade (FAZENDA, 2011). Acrescenta-se ainda que o ambiente não pode ser abordado separadamente por cada disciplina, mas em diversas dimensões que desenvolvam todas as atividades e seus aspectos físicos, biológicos, sociais e culturais dos seres humanos (SATO, 2003).

Ao longo dos anos a forma com que se efetiva a educação ambiental no ambiente escolar passou por diversas mudanças nos campos filosóficos e epistemológicos. Essas transformações levaram a uma diversidade de práticas e materiais didáticos que ainda se fazem presentes nas escolas. Avaliar essas práticas na busca por novas criações e caminhos é um processo constante de aprendizagem e contribuem para a transformação humana e social e a preservação ecológica (SATO, 2003).

O texto apresentado a seguir está estruturado da seguinte maneira: o $2^{\circ}$ capítulo apresenta os objetivos geral e específicos da pesquisa realizada, no Capítulo 3 se discute o ensino das ciências ambientais dentro de uma perspectiva centrada na 
educação ambiental. O Capítulo 3 se destina a apresentar uma revisão sobre os recursos didáticos utilizados na educação básica. $05^{\circ}$ Capítulo busca discutir a importância dos Indicadores de Desenvolvimento Sustentável. O $6^{\circ}$ Capítulo aprofunda as discussões sobre os Indicadores de Desenvolvimento Sustentável e aborda principalmente os Modelos de Análise desses Indicadores mais utilizados atualmente. $O$ Capítulo 7 consiste em uma revisão sistemática sobre a produção de materiais didáticos para o ensino das ciências ambientais. No Capítulo 8 é detalhada a metodologia da pesquisa utilizada durante o desenvolvimento do trabalho. Por fim, no Capítulo 8 são apresentados os resultados e as discussões sobre a pesquisa desenvolvida.

\subsection{Motivação e caracterização do problema}

A presente pesquisa justifica-se primeiramente na necessidade de analisar quais são os materiais didáticos que possibilitam a efetivação da educação ambiental nos contextos escolares, investigando como ocorrem os processos educativos ambientais mediados por materiais didáticos utilizados pelos professores da educação básica das escolas públicas.

Em um segundo momento, procura-se desenvolver materiais didáticos e um livro (com práticas educativas), que busque levar a discussão ambiental para o contexto escolar, possibilitando a renovação dos conhecimentos construídos nas práticas ambientais desenvolvidas pelos professores. Busca-se proporcionar mudanças na construção do processo de ensino-aprendizagem por parte dos professores e gestores, levando a uma educação ambiental crítica e reflexiva, desenvolvendo alunos engajados na análise e transformação dos espaços ambientais locais.

Procura-se responder as seguintes questões com o desenvolvimento da pesquisa: Como a Educação Ambiental e o Ensino das Ciências Ambientais está inserida na escola onde foi realizada a pesquisa e quais são seus principais recursos didáticos utilizados para seu desenvolvimento? Qual o impacto na aprendizagem sobre 
questões ambientais que o uso dos recursos didáticos atrelados aos indicadores de desenvolvimento sustentável e modelos de análise da sustentabilidade podem gerar?

\section{OBJETIVOS}

\subsubsection{Objetivo Geral}

Produzir uma sequência de atividades para o ensino das ciências ambientais nos anos finais do ensino fundamental, buscando com a análise do entorno escolar, construir uma proposta de Indicadores de Desenvolvimento Sustentável para a área estudada com a intenção de desenvolver uma visão crítica por parte dos alunos sobre os problemas ambientais presentes na sociedade.

\subsubsection{Objetivos Específicos}

- Investigar quais são os desafios e problemas encontrados na utilização de recursos didáticos para o ensino de ciências ambientais presentes no ambiente escolar.

- Analisar a importância do uso de diferentes recursos didáticos e dos indicadores de desenvolvimento sustentável para o apontamento de problemas presentes no entorno escolar pelos alunos dos anos finais do ensino fundamental.

- Desenvolver uma cartilha educativa com orientações para professores e alunos sobre como realizar uma análise do entorno escolar e construir indicadores de desenvolvimento sustentável, contribuindo assim para uma reflexão sobre a importância das questões socioambientais no contexto escolar. 


\section{O ENSINO DAS CIÊNCIAS AMBIENTAIS}

\subsection{Considerações iniciais}

Este capítulo tem por objetivo apresentar o conceito de ciências ambientais e a realizar uma curta revisão sobre a educação ambiental, levantando a importância da construção de uma conscientização individual e coletiva sobre os problemas presentes na sociedade e ambiente, bem como gerar ações que possam levar a redução ou solução desses desafios. Além disso, é apontada a relevância da interdisciplinaridade nesse processo de construção da ecocidadania nos ambientes escolares por parte dos professores.

\subsection{As Ciências Ambientais e a Educação Ambiental}

Miller Jr. (2007), em seu livro sobre a Ciência Ambiental, apresenta que ela se trata de um estudo sobre a natureza e seus demais elementos de forma interdisciplinar, aprendendo como nosso planeta funciona, a influência do ser humano nos demais seres vivos e os impactos ambientais gerados.

Para Quintas et al (2006), o processo de educação ambiental se efetiva quando o indivíduo entende que está inserido dentro de uma complexa relação entre a natureza e sociedade, assim se torna um agente capaz de compreender e comprometer-se com as questões socioambientais geradas pelas interversões humanas nos ambientes naturais ou construídos.

A educação ambiental, segundo Philippi Jr. e Pelicioni (2002), "é um processo de educação política que possibilita a aquisição de conhecimentos e habilidades, bem como a formação de atitudes que se transformam necessariamente em práticas de cidadania que garanta uma sociedade sustentável". Nesse mesmo viés pode-se dizer que a construção de uma ecocidadania proporciona uma conscientização individual e 
coletiva das responsabilidades locais e globais no respeito à vida, à ética ecológica e à defesa do direito a um mundo sem fronteiras geopolíticas (LOUREIRO, 2011).

Entende-se que os processos educativos não são neutros ou destituídos de valores e ideologias, mas sim cheios de subjetividade e escolhas políticas e de valores, representando diferentes papeis de acordo com suas intenções (LIMA, 2011). Nas escolas, mais do que transmitir conhecimentos sobre questões ambientais, a educação ambiental procura desenvolver o compromisso de transformação da sociedade e do indivíduo, pois, concordando com Loureiro (2012, p.99)

“É aquela que possui um conteúdo emancipatório, em que a dialética entre forma e conteúdo se realiza de tal maneira que as alterações da atividade humana, vinculadas ao fazer educativo, impliquem mudanças individuais e coletivas, locais e globais, estruturais e conjunturais, econômicas e culturais" (LOUREIRO, 2012, p.99).

Essa tendência emancipatória da educação ambiental foi discutida por Lima (2011) e tem por características:

- A compreensão multidimensional e complexa do ambiente;

- O desenvolvimento das liberdades humanas e não humanas;

- A atitude crítica com relação as crises civilizatórias;

- A politização e publicização da problemática ambiental em sua totalidade;

- A associação dos conhecimentos técnicos-científicos e não sua negação;

- A compreensão de que a participação democrática é um requisito básico para a sustentabilidade;

- O entendimento de que a participação social e a cidadania são práticas essenciais à Educação Ambiental e a democracia;

- O estímulo ao diálogo entre as ciências e das múltiplas dimensões da realidade, não dissociando ciências naturais e sociais, produção e consumo, interesses individuais e coletivos;

- A procura da construção de valores e práticas sociais atreladas ao bemestar público. 
Sendo assim, é exigido que o professor em suas atividades de educação ambiental, busque construir em seus alunos atitudes individuais e coletivas. Essa construção só é possível quando se adquire uma postura que adote diversas situações participativas, de conteúdo, perceptivas e sensoriais.

Os princípios apontados só se efetivam quando aplicados de forma interdisciplinar no ambiente escolar, pois, este é um caminho que proporciona diversos benefícios para a construção do conhecimento, podendo representar uma melhor formação geral que incentive uma educação permanente e significativa, com a possibilidade de modificar o indivíduo e o mundo em seus diversos aspectos (FAZENDA, 2001).

No contexto escolar, a efetivação de um estudo interdisciplinar dos conhecimentos pode ocorrer com a participação com diferentes disciplinas e saberes, sendo baseada na articulação de processos ecológicos, culturais, tecnológicos e pela contribuição de diferentes disciplinas nos campos da ecologia, tecnologia e etnociências (LEFF, 2007).

Esse diálogo só poderá ocorrer a partir de uma atitude interdisciplinar, pois a soma de opiniões isoladas, ou a justaposição levaria à manutenção das características já existentes na sociedade (FAZENDA, 2001). É por meio da complexidade de saberes que se torna possível a concretização de uma educação ambiental voltada para a formação da ecocidadania.

De acordo com Sorrentino (2011), é no diálogo da diversidade dos olhares que se busca respostas para o impasse que esse modelo de desenvolvimento impôs. É necessário acrescentar à educação ambiental as mais diversificadas formas de conhecimento para que se possa conhecer a realidade, fortalecer a ação coletiva, articular os saberes na busca por soluções de problemas e compreender o ambiente em sua complexidade e a vida em sua totalidade (LOUREIRO, 2012).

\subsection{Considerações finais}


Como apontado durante o capítulo, a educação ambiental adquire um papel de grande relevância na redução e solução dos complexos problemas ambientais, sociais e econômicos presentes na sociedade. Desta forma, para o presente trabalho considera-se que há uma necessidade de que no ambiente escolar haja uma busca pela integração de diferentes áreas do conhecimento para que o aluno possa exercer seu papel de ecocidadão. 


\section{MATERIAIS DIDÁTICOS}

\subsection{Considerações iniciais}

Esse capítulo busca discutir o uso de diferentes recursos didáticos para construção do processo de ensino e aprendizagem no contexto escolar. Além disso, procura conceituar o termo recurso didático e abordar suas potencialidades para a educação ambiental, principalmente por meio do uso de materiais didáticos em aulas práticas e de campo.

\subsection{Definições e conceitos}

No ambiente escolar o professor se utiliza de diferentes recursos didáticos durante suas situações de ensino e aprendizagem. Seu uso apresenta diversas características e está relacionado principalmente aos temas que estão sendo estudados, assim quando se refere ao Ensino das Ciências Ambientais não se pode deixar de apontar sua relevância no desenvolvimento de atividades que busquem proporcionar novos conhecimentos sobre questões ambientais, sociais e econômicas.

Fiscarelli (2008) considera que diferentes recursos, tanto materiais quando naturais podem ser utilizados como materiais didáticos. Pode-se citar desde o giz do professor aos espaços naturais que são utilizados para a realização das atividades, em outras palavras, entende-se que qualquer recurso, natural ou construído serve como meio para o ensino e aprendizagem durante as aulas. Seguindo essa consideração, Leodoro (2001) aponta que os objetos, independentes da origem, industrializados ou construídos pelo professor e/ou aluno, podem favorecer o conhecimento sobre 0 mundo.

Uma das classificações dos recursos didáticos foi feita por Piletti (2004), que, segundo o autor, divide-se em duas grandes categorias tais recursos: recursos humanos e recursos materiais. No primeiro grupo encontram-se inseridos os 
professores, alunos, pessoal escolar e a comunidade. Para a segunda classe têm-se duas subdivisões: do ambiente, relacionado as questões naturais e escolar; e da comunidade, envolvendo bibliotecas, indústrias, comércios e espaços públicos.

Contudo não basta apenas crer que o simples e diversificado uso desses recursos em sala de aula é por si só sinônimo de uma boa educação. A utilização desses recursos deve responder a questões essenciais que possibilitem deixar claro o que se pretende com seu uso, quando ele será aplicado, como será a atividade e com qual objetivo. Dessa maneira entende-se que existe todo um contexto e propósito para sua aplicação, os recursos se tornam um elemento de mediação entre o professor e o aluno na busca pelo conhecimento (SOUZA, 2007).

Como consequência dessa discussão, Fiscarelli (2008) levanta que a efetivação do uso desses recursos no ambiente escolar esbarra principalmente em dois fatores: um relacionado ao envio de materiais às escolas, ou seja, a disponibilidade do material para uso em sala de aula e outro relacionado à sua utilização por parte dos professores. Assim leva-se em consideração que além do professor possuir o material para ser utilizado ele necessita refletir sobre como aplica-lo durante as situações de ensino-aprendizagem.

Nos estudos feitos por Luz (2006) e Reis et al (2013) observa-se que ainda para os professores é mais comum e prático o uso dos livros didáticos, do quadro e giz e de vídeos durante as aulas. Esses recursos no geral geram pouca aprendizagem por parte dos alunos, sendo mais efetivos aqueles em que há uma discussão e realização de ações por parte dos sujeitos, ou seja, em que eles são envolvidos durante todo o processo de seu desenvolvimento (PILETTI, 2004).

Zannon e Freitas (2007) discutem que os recursos didáticos não devem buscar apenas uma apresentação dos conteúdos e a participação em aula, mas ampliar a criatividade dos alunos, gerando curiosidade, o teste de ideias e que estejam relacionadas ao seu cotidiano, sendo desenvolvida ao longo da observação direta dos fenômenos. Dessa forma, Silva e Zannon (2000) acrescentam que, apesar de negligenciadas, as aulas práticas podem despertar o interesse dos estudantes quando deixam de ser repetitivas e com caráter superficial. 
Pouco utilizada pelos professores, mas que geram grandes impactos na educação ambiental, as aulas práticas que envolvem experimentação e saídas de campo servem como recursos para análise do meio e construção do conhecimento nas ciências ambientais. Segundo Viveiro e Diniz (2009), essas atividades proporcionam ao aluno o contato e interação com situações reais onde ocorre o estímulo à curiosidade $\mathrm{e}$ aos sentidos, gerando uma maior relação entre a teoria e prática.

Ainda segundo Viveiro (2006), as atividades de campo contribuem para educação ambiental quando deixam de ser apenas uma extensão da sala de aula e apresentam uma construção que envolva o planejamento, a execução, exploração dos resultados e avaliação do processo. Assim, entende-se que para sua realização o professor necessita estar preparado para conduzir os alunos na análise e reflexão sobre os fenômenos descobertos durante a atividade.

\subsection{Considerações finais}

Como discutido, entende-se que um recurso didático supera a ideia de um simples material a ser utilizado em uma aula, envolvendo todo um contexto de utilização em diferentes situações de ensino. Para o desenvolvimento deste trabalho foram utilizados diferentes recursos didáticos durante o processo de construção dos indicadores de desenvolvimento sustentável, sendo que tem como foco a participação dos alunos em sua construção e reflexão sobre os fenômenos analisados. 


\section{INDICADORES DE DESENVOLVIMENTO SUSTENTÁVEL}

\subsection{Considerações iniciais}

No presente capítulo são apresentadas as concepções sobre os Indicadores de Desenvolvimento Sustentável e sua importância para o planejamento governamental, além de discutir os princípios de construção desses indicadores.

\subsection{Definição e conceitos}

O Instituto Brasileiro de Geografia e Estatística (IBGE), órgão responsável pela publicação dos Indicadores de Desenvolvimento Sustentável (IDS) no Brasil, define que:

\footnotetext{
"Os indicadores de desenvolvimento sustentável são instrumentos essenciais para guiar a ação e subsidiar o acompanhamento e a avaliação do progresso alcançado rumo ao desenvolvimento sustentável. Devem ser vistos como um meio para se atingir o desenvolvimento sustentável e não como um fim em si mesmos. Valem mais pelo o que apontam que pelo seu valor absoluto e são mais úteis quando analisados em seu conjunto que o exame individual de cada indicador". (IBGE, 2015, p.12)
}

Dessa forma entende-se que a utilização dos indicadores possibilita uma visão ampla e interligada de diferentes fatores importantes para o desenvolvimento sustentável. Além disso, segundo Malheiros et al (2008), os indicadores de sustentabilidade facilitam a avaliação dos resultados apresentados durante o processo de busca pela sustentabilidade definidas nas metas governamentais. Sendo assim, se tornam parâmetros que possibilitam o acompanhamento e servem de base para as tomadas de decisão pelas diferentes esferas sociais.

Veiga (2010) observa que apesar dos esforços crescentes ainda se faz necessário uma maior interação entre os indicadores, enfatizando principalmente 
medidas que busquem avaliar, mensurar e monitorar os mais variados indicadores, procurando aprofundar os avanços já alcançados.

Um dos grandes referenciais para a produção de indicadores está presente nos "Princípios de Bellagio" (IISD, 2000) que aponta os seguintes princípios para a construção de indicadores:

1- Guia de Visão e Metas- Devem ser claros e guiados por uma visão de desenvolvimento sustentável.

2- Perspectiva Holística- Precisam apresentar uma visão holística sobre todos os elementos presentes em nosso planeta, integrando questões ambientais, sociais e econômicas. Acrescenta-se nesse princípio as consequências da atividade humana sobre os demais seres e sistemas naturais, dentro de uma perspectiva monetária e não monetária.

3- Elementos Essenciais- Necessitam estar atentos aos elementos essenciais para os seres vivos e recursos naturais, em outras palavras, considerar a utilização sustentável dos recursos de forma justa pelas gerações atuais e futuras, contribuindo para o bem-estar.

4- Escopo adequado- Possuir uma abrangência nas escalas de tempo, proporcionando uma visão histórica mais ampla dos fenômenos. Os estudos devem ser definidos desde aos impactos locais aos globais durante períodos longos com decisões em curto prazo.

5- Foco prático- Sua construção e interpretação deve apresentar características que possibilitem sua praticidade, ou seja, com organização das metas e dos critérios de avaliação claros e concretos.

6- Transparência- Os dados e indicadores devem ser de fácil acesso às pessoas, deixando claro as críticas, pressupostos e incerteza dos dados.

7- Comunicação efetiva- Os resultados devem chegar às pessoas de maneira que se possa compreender o que está sendo demonstrado de forma universal e democrática, atendendo as necessidades e respeitando as características dos grupos. Além disso, devem ser estruturados de forma sistêmica e que auxiliem na tomada de decisões. 
8- Ampla Participação- Para representar de forma efetiva as necessidades da sociedade é necessário que todos possam participar de sua construção, garantindo o envolvimento para que as decisões se concretizem.

9- Avaliação Constante- Como a produção dos indicadores e sua análise faz parte de um processo, torna-se importante que a avaliação seja algo comum e que busque atender todos os demais princípios.

10-Capacidade Institucional- Os resultados e todo o desenvolvimento dos estudos devem ser incentivados nos diferentes níveis organizacionais, definindo responsabilidades e apoio para tomada de decisões. Busca-se também manter a coleta de dados, sua manutenção e registro inclusive com participação efetiva da comunidade local.

Posteriormente para análise dos dados produzidos e a definição dos indicadores, se faz necessário o uso de modelos para análise e relação desses indicadores. Nesse estudo o foco estará nas discussões com base no Modelo PEIR, que será discutido com maior profundidade no próximo capítulo.

\subsection{Considerações finais}

Nesse capítulo foram apresentados os conceitos de Indicadores de Desenvolvimento Sustentável e os princípios que envolvem sua construção, buscando parâmetros que possibilitam sua avaliação e diagnóstico na aplicação dentre de um contexto escolar. Entende-se que sua construção é de grande complexidade e envolve a participação de diferentes atores sociais e organizações, mesmo assim, é importante ressaltar que sua aplicação nas situações de ensino auxilia na construção de alunos que possam participar no futuro da tomada de decisões na esfera pública. 


\section{MODELOS DE ANÁLISE DOS INDICADORES DE DESENVOLVIMENTO SUSTENTÁVEL}

\subsection{Considerações iniciais}

O referido capítulo tem objetivo de apresentar o uso dos Indicadores de Desenvolvimento Sustentável com base em diferentes modelos de análise ambiental, buscando discutir os diferentes modelos que embasam o presente trabalho, fornecendo possíveis soluções sobre os problemas ambientais presentes no entorno escolar.

\subsection{Definições e conceitos}

A fim de monitorar e avaliar os diferentes aspectos ambientais e suas consequências sobre o ser humano, nas últimas duas décadas foram desenvolvidos diversos modelos para análise de indicadores. Em 1993 a Organização para Cooperação e Desenvolvimento Econômico (OCDE) começa a se utilizar do Modelo PER (pressão-estado-resposta), posteriormente acrescentaria em sua análise o I (impacto), sendo renomeado para PEIR (pressão-estado-impacto-resposta). Outros modelos desenvolvidos foram propostos pelas Nações Unidas em 1996, o DSR (força motriz-estado-resposta) e pela Agência Ambiental Europeia em 1999 o DPSIR (força motriz-pressão-estado-impacto-resposta) (MALHEIROS et al, 2008).

No Brasil, como fruto das discussões realizadas, optou-se por utilizar um modelo temático, dividido, segundo a Agenda 21, em diferentes áreas para análise das condições existentes em nosso país, em quatro dimensões: ambiental, social, econômica e institucional (IBGE, 2015). Contudo ainda são encontrados documentos publicados pela PNUMA e por demais órgão que se utilizam do Modelo PEIR para suas análises, entre eles o GEO Cidades (PNUMA, 2004), GEO Brasil (IBAMA, 2002) e o PNIA- Programa Nacional de Indicadores Ambientais (MMA, 2012). 
Este trabalho foca-se no modelo desenvolvido pelo Programa das Nações Unidas para o Meio Ambiente (Pnuma) que construiu uma abordagem que busca responder as necessidades da organização e análise dos indicadores de desenvolvimento sustentável, o Modelo Pressão-Estado-Impacto-Resposta (PEIR). Segundo Sobral et al (2011), a construção de informes baseados neste modelo tem como objetivo fornecer dados para a tomada de decisões pelos gestores públicos, além de ser uma ampla base de informações sobre as condições ambientais visando a solução dos problemas encontrados.

Segundo Silva et al (2012), o modelo PEIR desenvolvido pela OCDE pode ser adaptado às necessidades da pesquisa que está sendo realizada, tendo também como objetivo deixar de forma clara as informações que são construídas durante os estudos. Para a sociedade esse estudo possibilita e apresenta como função a análise, comunicação e sensibilização sobre os resultados obtidos.

Os documentos GEO Brasil (p. 10, 2002) e PNIA (p. 15, 2012) apresentam a metodologia de análise da seguinte forma:

Pressão: Se relaciona com os processos e atividades que agem sobre o meio ambiente produzindo mudanças nas condições naturais. Essas pressões estão associadas às ações realizadas pela sociedade sobre o meio ambiente. Estão relacionadas também com o modelo de produção e consumo presente na sociedade e que impactam diretamente ou indiretamente o estado do meio ambiente. Como exemplo tem-se as questões de crescimento demográfico, urbanização, industrialização, elevados padrões de consumo, a desigualdade econômica e social.

Estado: Relaciona-se com as condições do ambiente e socioeconômica, gerando situações que afetam a qualidade de vida dos seres vivos. Os indicadores dessa categoria são importantes, pois auxiliam na tomada de decisões políticas e estão diretamente ligadas às pressões exercidas pela sociedade e com a qualidade e quantidade dos recursos naturais ou seres vivos. Pode-se apontar como indicadores dessa categoria os elevados índices de poluição do ar, a degradação e contaminação do solo e a redução da disponibilidade de água ou perda de sua qualidade.

Impacto: As mudanças no estado do ambiente geram impactos para a sociedade. Essa categoria está ligada a condição de saúde da população, dos seres vivos, 
ecossistemas, economia entre outros aspectos. Relacionando com os tópicos apresentados anteriormente entende-se que com a poluição do ar torna-se comum problemas de saúde cardiorrespiratórios; a degradação do solo prejudica a produção de alimentos, produzindo um aumento do uso de recursos para fertilização; e a disponibilidade e qualidade da água, gera impactos sobre a saúde, alimentação, lazer e econômico aos seres humanos.

Resposta: São as ações feitas buscando prevenir ou reduzir os impactos gerados pela ação humana. Em linhas gerais podem ser resultado de ações voltadas para transformações no estado e nos impactos, além de terem como principal foco a redução das pressões exercidas pela sociedade. As respostas envolvem situações onde ocorre a criação e regulamentação de leis nacionais, estaduais e municipais, a produção de instrumentos para análise e tomada de decisões sobre as condições, pressões e impactos ambientais.

\subsection{Considerações finais}

Pode-se dizer que os diferentes aspectos analisados nos modelos de construção dos indicadores de desenvolvimento sustentável fornecem dados que auxiliam as decisões dos poderes públicos, buscando apresentar e solucionar os desafios encontrados, proporcionando além disso, informações necessárias à sociedade. 


\section{A CONSTRUÇÃO DE MATERIAIS DIDÁTICOS PARA O ENSINO DAS CIÊNCIAS AMBIENTAIS: UMA REVISÃO SISTEMÁTICA}

\subsection{Considerações iniciais}

Para além das bases teóricas que fundamentam este trabalho, busca-se com este capítulo apresentar uma revisão sistemática que auxilie a conhecer as discussões já realizadas sobre a temática do uso de recursos didáticos para o Ensino das Ciências Ambientais em diferentes trabalhos publicados. Esse recorte se faz necessário, pois o presente programa de pós-graduação envolve o ensino das ciências ambientais, temse, portanto, a intenção de identificar os materiais utilizados em pesquisas na área, discutindo a sua aplicação em sala de aula.

\subsection{Planejamento}

Uma das etapas mais importantes da revisão sistemática consiste no planejamento. Busca-se definir os objetivos, as questões, as fontes de busca e os critérios de seleção dos estudos encontrados.

\subsubsection{Objetivos da Revisão Sistemática}

Esta revisão sistemática tem os seguintes objetivos:

- Identificar os trabalhos que discutem a produção de materiais didáticos para o ensino das ciências ambientais;

- Selecionar os textos que se relacionam com a presente pesquisa na intenção de proporcionar uma base teórica sólida e atual para seu desenvolvimento; 
- Analisar os estudos já realizados sobre o ensino das ciências ambientais e sua aplicação no âmbito escolar.

\subsubsection{Questões}

Seguindo os objetivos propostos procura-se responder às seguintes questões após a revisão sistemática:

- Existem trabalhos que inserem o ensino das ciências ambientais na educação básica?

- Quais são as práticas escolares mais utilizadas para o ensino das ciências ambientais?

\subsubsection{Seleção das fontes}

As bases de dados utilizadas para a revisão sistemática foram selecionadas devido a sua capacidade de englobar o maior número de revistas e trabalhos acadêmicos que pudessem ser consultadas de forma total e aberta. Assim, as bases de busca utilizadas são:

- Scielo

- Scopus

- Web of Science

\subsubsection{Seleção dos estudos}

Para a seleção dos estudos foram definidos também as palavras-chave, os critérios de inclusão e exclusão da pesquisa. 


\section{Palavras-chave}

Ensino: teaching, instruction, didactic, education

Ciências Ambientais: environmental sciences

Educação Ambiental: environmental education

Materiais Didáticos: teaching materials, teaching tools, didactic resources

\section{Critérios de Inclusão}

Buscando delimitar a pesquisa, os seguintes critérios de inclusão foram adotados para que se atingisse os objetivos propostos para a revisão sistemática:

- Estudos que envolvam o ensino das ciências ambientais;

- Estudos que englobem a produção de materiais didáticos para o ensino das ciências ambientais ou educação ambiental.

\section{Critérios de Exclusão}

Os trabalhos encontrados foram selecionados observando os seguintes critérios de exclusão, assim sendo retirados da revisão sistemática:

- Estudos que não estejam relacionados com o ensino das ciências ambientais ou educação ambiental;

- Estudos que não abordem a construção de materiais didáticos para o ensino das ciências ambientais ou educação ambiental;

- Estudos que não estejam em português, inglês ou espanhol;

- Estudos que tenham sido publicados na forma de resumos. 


\section{Procedimentos para selecionar os estudos}

- Busca de trabalhos: inicialmente foram realizadas as buscas nos bancos de dados seguindo as palavras-chave definidas.

- Seleção prévia: os resultados encontrados passaram por uma triagem, por meio da leitura de seus respectivos resumos. Sendo selecionados de acordo com os critérios de inclusão e exclusão.

- Seleção final: os trabalhos que foram selecionados passaram por uma leitura completa de seu conteúdo.

- Produção de síntese: após a leitura, os trabalhos foram sintetizados para possibilitar um melhor entendimento de suas discussões e facilitar a apresentação na revisão sistemática.

\subsection{Execução}

A apresentação da execução foi dividida em duas partes: a construção das strings de busca e a análise dos resultados.

\subsubsection{Construção das strings de busca}

- Scopus: Title-Abstract-Key ((teaching or instruction or didactic or education) and ("environmental science" or "environmental education") and ("teaching material" or "teaching tool" or "didactic resource")).

- Scielo: Todos os índices ((teaching or instruction or didactic or education) and ("environmental science" or "environmental education") and ("teaching material" or "teaching tool" or "didactic resource")).

- Web of Science: Tópico ((teaching or instruction or didactic or education) and ("environmental science" or "environmental education") and ("teaching material" 
or "teaching tool" or "didactic resource")); Título ((teaching or instruction or didactic or education) and ("environmental science" or "environmental education") and ("teaching material" or "teaching tool" or "didactic resource")).

\subsubsection{Resultados das buscas}

No total foram encontrados 86 trabalhos com as buscas realizadas nas bases já mencionadas e com as strings de busca definidas anteriormente. Dessa forma pode-se observar na Figura 1 a proporção de trabalhos por base de busca.

Figura 1: Contagem do número de trabalhos encontrados segundo as bases de pesquisa.

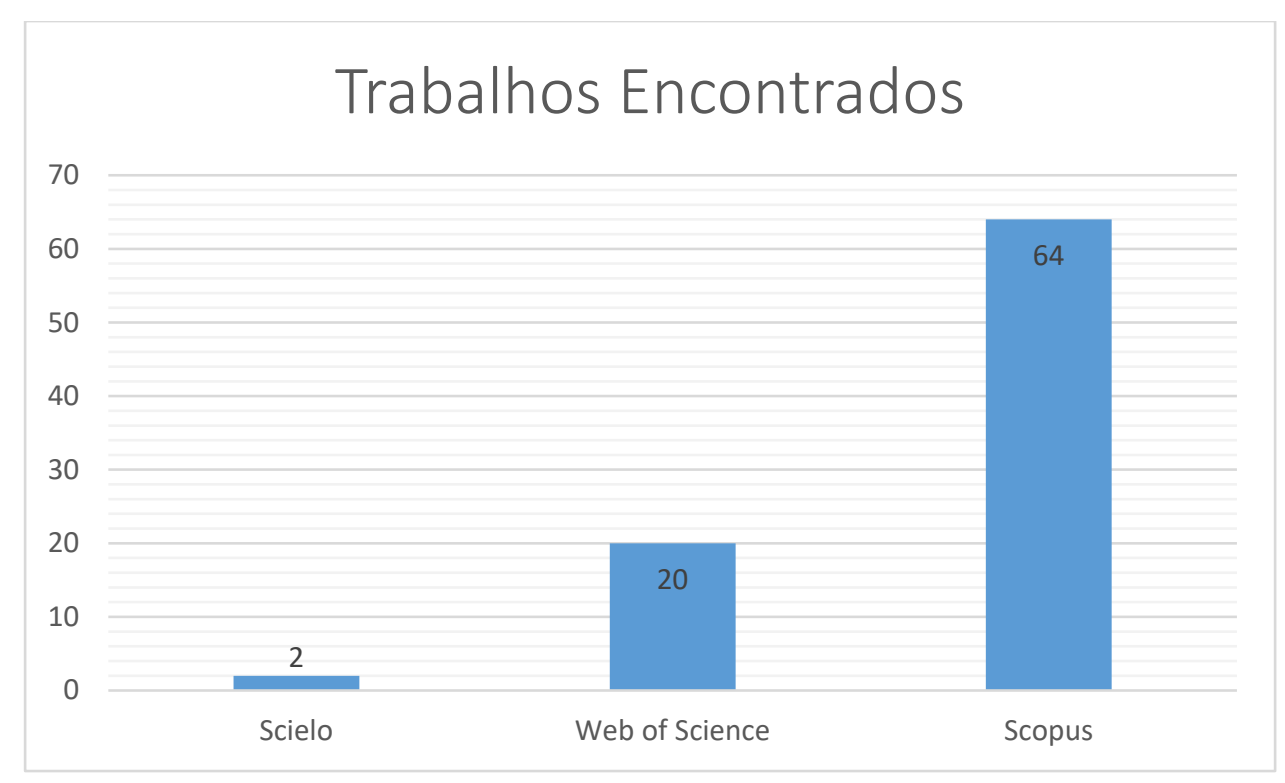

Fonte: Arquivo do autor

Após a leitura dos resumos presentes nos trabalhos, eles foram selecionados de acordo com os critérios de inclusão e exclusão definidos na Seção 6.2.4. Desta forma, a quantidade de trabalhos aceitos e rejeitados podem ser verificadas na Figura 2: 
Figura 2: Contagem do número de trabalhos selecionados segundo as bases de pesquisa.

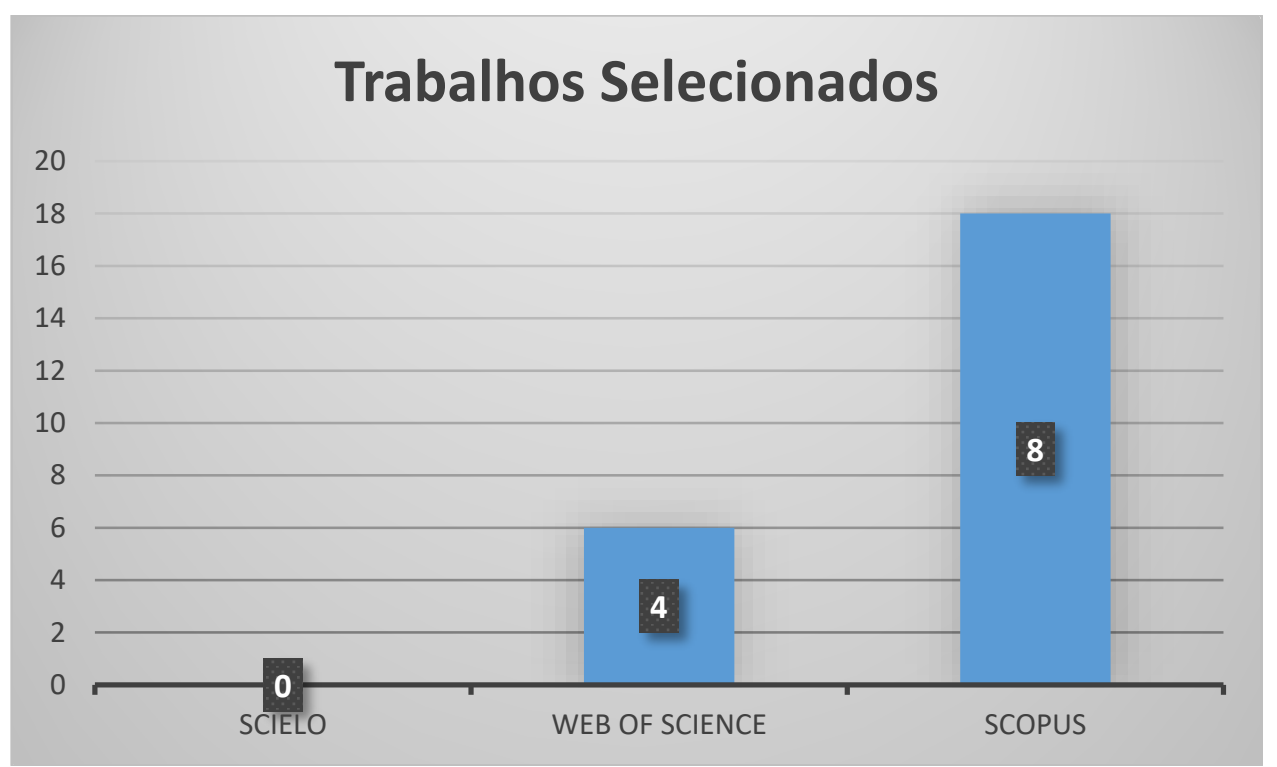

Fonte: Arquivo do autor

Com a segunda seleção, feita por meio da leitura completa dos trabalhos chegou-se a 12 aceitos, distribuídos segundo as bases de busca. Foram retirados desse valor 6 artigos que estavam duplicados durante as buscas.

\subsection{Síntese dos Resultados}

O uso de diferentes materiais didáticos para o ensino das ciências ambientais ou na educação ambiental se torna essencial para o melhor desenvolvimento das atividades realizadas, bem como para uma melhor compreensão dos alunos sobre os 
temas abordados. Dessa forma foram encontrados vários estudos que apontam o uso de tais recursos na aplicação de atividades sobre a temática ambiental.

Chang et al. (2010), em estudo sobre o uso de tecnologia nas aulas sobre educação ambiental, aponta que o WebQuest atrelado a atividades ao ar livre possibilitam uma melhor compreensão da importância da proteção ambiental, bem como os impactos resultantes para o ambiente da poluição. Para chegar a essa conclusão os autores produziram um conjunto de atividades a serem desenvolvidas em um centro de reciclagem, onde se utilizou do material didático WebQuest os alunos anotavam as observações, pesquisavam as possíveis respostas e discutiam os resultados em grupo.

Em outro estudo desenvolvido por Ma e Shin (2015) foi utilizado um instrumento que simula os efeitos da Chuva Ácida nos ambientes. Com esse recurso os alunos podem observar a formação e os impactos que esse problema ambiental pode gerar. Os resultados apontam que essa ferramenta é eficaz para o aprendizado e possibilita discussões sobre o tema, além de motivar os alunos e professores sobre a qualidade ambiental dos locais.

Gazalbo e Núñez (2016) apresentam e discutem o uso de hortas orgânicas como um recurso de ensino e aprendizagem na educação ambiental. Para o estudo realizaram três experiências com turmas diferentes, que envolviam a construção de hortas nas escolas e que foram utilizadas para discussões sobre diferentes conceitos como, por exemplo, a questão do solo e sua importância. Como conclusão os autores apontam que essas atividades proporcionam uma aprendizagem dos alunos, além de gerar um envolvimento emocional que os conecta com o seu ambiente. Também destacam que ela possibilita uma interação social e o trabalho colaborativo entre os envolvidos na produção da horta.

Yamamoto e Ma (2016) desenvolveram um instrumento que simula uma Usina Termoelétrica para a compreensão dos impactos causados, como a poluição do ar. $\mathrm{O}$ estudo envolveu a produção de uma usina onde os alunos pudessem observar a produção de energia elétrica e a consequência da queima de combustíveis nesse processo. As autoras apontam como motivação a melhoria da qualidade ambiental e em específico a condição pela qual o Japão passou em anos anteriores quanto as 
usinas nucleares, onde os alunos descrevem que é uma das maiores preocupações nas questões ambientais. Os resultados apresentados demonstram que o uso desse recurso contribui para a aprendizagem dos alunos e também para compreensão sobre os problemas ambientais resultantes da queima de combustíveis fósseis.

Bednarz (2004), em seu estudo sobre o uso de SIG (Sistema de Informação Geográfica) no estudo de questões ambientais aplicadas na Educação Ambiental, demonstrou que apesar da tecnologia nos últimos anos ser amplamente utilizada por pesquisadores de diferentes áreas, ainda se nota pouco uso nos ambientes escolares. Como resultado, aponta que o recurso ao ser aplicado com os alunos possibilita um desenvolvimento do pensamento e do raciocínio quanto as questões espaçoambientais, o que contribui para uma educação ambiental mais ampla.

Outro importante recurso utilizado para a discussão sobre questões ambientais foi apresentado por Savita et al. (2017). Em seu estudo fica claro que o uso de celulares atrelados a aplicativos possibilita a compreensão e engajamento dos alunos aos problemas ambientais existentes. Para chegar a essa conclusão, desenvolveram um aplicativo "LOVE2GreenMY" que, por meio de uma sequência de atividades, conduz os alunos a discutirem diferentes situações relacionadas ao meio ambiente. Um dos exemplos citados no artigo envolve a apresentação, discussão e realização de desafios relacionados ao consumo de energia e seus impactos para a sociedade e meio ambiente.

Nesta mesma perspectiva, Mioduski e Francisco (2013) exploram o uso do Blog como ferramenta para a Educação Ambiental. A capacitação de professores para a criação de um blog proporcionou, segundo o estudo, um maior interesse dos mesmos pela temática ambiental, favorecendo a autonomia dos docentes e dos discentes, a aquisição de novos conhecimentos e saberes que unem a tecnologia e a educação ambiental. Apontam ainda que apesar do crescimento do uso de novos recursos educacionais aplicados a Educação Ambiental, ainda são necessárias novas pesquisas que busquem unir esses dois setores.

Baião e Batista (2016) utilizam, como instrumento de ensino sobre questões hídricas, um protocolo de avaliação rápida (PAR) no estudo sobre a Bacia do Rio Paraíba do Sul com alunos do ensino fundamental. Segundo os autores, o uso de tal 
recurso, no decorrer de uma sequência didática que envolve aulas de campo, proporciona aos professores um bom instrumento para educação ambiental. Além disso apontam que ele serve como estímulo nas discussões de como a escola e os alunos podem participar de forma ativa e transformadora na gestão das águas, contribuindo para a participação social na tomada de decisões quanto ao gerenciamento dos recursos hídricos.

Em um estudo sobre o desenvolvimento e implementação de um ambiente virtual de aprendizado sobre ecossistemas, biodiversidade e questões ambientais, Yucel e Ozkan (2015) destacam que o uso de recursos virtuais atrelados a questões da vida real dos alunos tem grande influência na construção de conhecimentos e atitudes ambientais. Descrevem que a produção desse recurso deve ser pautada na diversidade de fontes de informação e na qualidade das discussões propostas durante as atividades. Também acrescentam a necessidade de que, além das atividades online, sejam necessárias ações que coloquem em prática aquilo que fora apreendido durante o curso feito na internet.

Madruga e Silveira (2002), ao realizarem uma pesquisa com o objetivo de levar adolescentes a discutir questões ambientais com crianças mais novas, demostraram que é possível que o tema seja abordado por pessoas de diferentes idades e níveis de instrução. Como resultado apontam que são necessárias ações que busquem a discussão e o incentivo à participação dos alunos do ensino fundamental e médio no processo de resolução dos problemas ambientais atualmente presenciados.

Ao analisar livros infantis que abordam questões ambientais, Muthukrishnan e Kelley (2016) apontam que pouco se discute sobre a sustentabilidade e o impacto que as crianças, como consumidoras, geram com suas escolhas. Dessa forma destacam que nos livros infantis a relação entre homem e natureza, não engloba as crianças como um ator participante desse processo, deixando de realizar a conexão delas com os demais seres vivos, por exemplo. Outro ponto apresentado pelos autores está no fato de que as discussões presentes nos livros estão focadas apenas no pós-consumo, toda a etapa de produção e os impactos que esse processo gera são omitidos nos livros. 
Horta et al. (2015) propõem como alternativa à educação e à consciência ambiental a produção de um jogo eletrônico no estilo Role Playing Game (RPG). Após a produção e aplicação do jogo com os alunos, os autores descrevem que ele serviu como uma ferramenta que melhora a assimilação dos conceitos estudados em sala, motivando o aprendizado e auxiliando na produção do próprio conhecimento por parte dos alunos. Apontam que as ações desenvolvidas pelo personagem dentro do jogo devem estar relacionadas a ações ambientalmente corretas e isso faz com que os alunos transportem esses conhecimentos para o seu dia-a-dia.

\subsection{Considerações finais}

Por meio das buscas por pesquisas na temática apresentada, esse capítulo proporcionou o encontro das discussões já presentes no Ensino das Ciências Ambientais com as propostas apontadas nesta pesquisa, a fim de identificar e selecionar estudos que contribuam para a construção de recursos didáticas para construção dos Indicadores de Desenvolvimento Sustentável sob a perspectiva da área. 


\section{METODOLOGIA}

\subsection{Considerações iniciais}

Este capítulo apresenta a metodologia da pesquisa, buscando detalhar em partes todo processo da construção da mesma. Tem como finalidade possibilitar uma visão ampla de seu desenvolvimento, bem como as etapas de construção do produto educacional proposto, sua aplicação, análise e discussão.

\subsection{Procedimentos metodológicos}

A presente pesquisa foi desenvolvida mediante a aplicação dos fundamentos da pesquisa participante (FLICK, 2004). Entende-se que as práticas realizadas devem conter instrumentos de coleta dos dados e que após a realização de cada uma, os dados serão avaliados segundo critérios específicos.

As etapas de desenvolvimento e coleta de dados da pesquisa foram desenvolvidas na Escola Municipal de Educação Básica Professor Erotides de Campos da cidade de Charqueada/SP. Todos os alunos participantes e seus respectivos responsáveis assinaram o Termo de Consentimento Livre e Esclarecido, sendo reservado $\mathrm{o}$ anonimato dos alunos durante a apresentação deste trabalho. Posteriormente essas atividades propostas serão descritas com maior detalhe. $\mathrm{Na}$ Figura 3 estão representadas as etapas relacionadas à execução da proposta.

Figura 3: Representação das etapas de execução da pesquisa

Produção do da

imagem de

satélite com

legendas

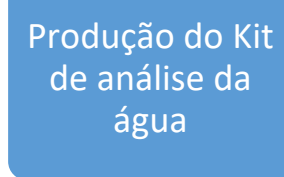

Produção do Kit

água 
A etapa inicial do trabalho envolve a produção de um mapa com o objetivo de facilitar a análise do entorno escolar. Como base para sua produção, foram levantados diferentes elementos presentes no bairro que foram categorizados em três: ambiental, social e econômico. Para produção dos materiais didáticos foram adotados os seguintes procedimentos metodológicos:

1- Produção de uma imagem de satélite com a identificação dos elementos presentes no entorno escolar.

a. Pesquisa de campo

i. Produção econômica

1. Comércio

2. Indústria

3. Pequenos comerciantes e produtores

ii. Elementos sociais e naturais

1. Áreas naturais (rios e árvores)

2. Espaços públicos

3. Espaços culturais e religiosos

iii. Problemas ambientais

1. Esgoto

2. Lixo

3. Desmatamento

iv. Transformações nas paisagens

1. Comparação de fotografias

2. Relato de moradores

b. Construção de ícones e legendas para a imagem de satélite com os dados obtidos na pesquisa de campo

c. Construção e finalização da imagem de satélite com os elementos encontrados no entorno escolar

d. Aprofundamento dos dados obtidos- uso de materiais para análise e definição dos pontos de interesse com problemas ambientais 
2- Construção de um Kit de baixo custo para análise da água

3- Sistematização dos dados obtidos utilizando o Modelo PEIR

4- Criação de Indicadores de Desenvolvimento Sustentável para o bairro.

Por se tratar de uma pesquisa desenvolvida em um mestrado profissional, a última etapa contempla a produção de um livro (cartilha), disponibilizado pela internet no site https://sites.google.com/usp.br/analisandooentornoescolar/página-inicial, contendo a sequência de produção dos materiais didáticos e sua utilização em sala de aula. O material contém os seguintes itens:

- Introdução

- Estrutura e organização do livro

- Sequência de atividades para construção dos Indicadores de Desenvolvimento Sustentável

- Referências Bibliográficas

- Anexos

Além das ações mencionadas anteriormente, entende-se que os questionários e entrevistas são importantes, pois constituem diversas fontes de dados que auxiliam na análise e busca por resultados na pesquisa (LÜDKE; ANDRÉ; 1986). Para análise das respostas feitas na entrevista e questionário foram utilizados alguns referenciais teóricos sobre interdisciplinaridade, educação ambiental nas práticas pedagógicas e recursos didáticos (FAZENDA, 2001; LUDKE; ANDRÉ, 1986; MOREIRA, 2011; LOUREIRO,2012; SATO,2003; FISCARELLI, 2008). Os questionários e entrevistas se encontram na secção de apêndices.

Entende-se que as atividades práticas constituem um significado importante para compreensão de conteúdo e alfabetização científica, na qual foram utilizadas pesquisas com embasamento teórico para seleção dessas atividades. De acordo com Vasconcelos et. al (2005), as aulas práticas não devem ser consideradas apenas ferramentas de ensino, mas que contenham um caráter social e reflexivo, que o aluno 
consiga além de aprender sobre o conteúdo específico, respeitar a opinião de seus colegas, como também expor suas ideias e questionamentos.

\subsubsection{Produção da imagem de satélite com os elementos encontrados no entorno escolar}

A produção da imagem de satélite com os elementos encontrados no entorno escolar caracteriza-se por ser uma ação que tem por objetivo desenvolver nos alunos habilidades relacionadas a localização e levantamento de dados sobre o entorno escolar. Nesta etapa foi prevista a seguinte sequência de trabalho:

- Coleta de dados inicial: Aplicação do questionário inicial, com o objetivo de obter informações sobre o uso de recursos didáticos pelos alunos;

- Distribuição de mapas do bairro para os alunos;

- Formação de grupos para análise do entorno escolar com base em quatro aspectos a serem observados: economia; espaços públicos e naturais; problemas ambientais; transformações nas paisagens;

- Saída de campo para levantamento de dados;

- $2^{\mathrm{a}}$ coleta de dados: entrevista em grupo, aplicação do questionário inicial e produção de resumo individual com os impactos, estado do ambiente e responsáveis pelas alterações;

- Sistematização dos dados obtidos pelos alunos;

- Produção de ícones e legendas para a imagem de satélite com base nos dados obtidos por eles;

- Produção final da imagem de satélite com os elementos encontrados no entorno escolar.

A segunda coleta de dados tem como foco o levantamento de informações sobre os elementos que mais se destacam nas observações realizadas pelos alunos e quais as relações existentes entre os problemas ambientais encontrados e seus possíveis 
responsáveis. Dessa forma as respostas dos alunos foram gravadas para posterior análise.

A análise envolve a categorização das respostas de acordo com o Modelo PEIR: Pressão, Estado, Impacto e Resposta. Assim, espera-se obter dados sobre o conhecimento prévio dos alunos sobre as relações existentes entre o estado do ambiente e seus responsáveis. Essa análise foi retomada para posterior discussão sobre os efeitos das atividades propostas para o desenvolvimento dos alunos após as ações realizadas.

\subsubsection{Produção do Kit de Análise da Água}

A produção do Kit de Análise da Água possui duas etapas distintas. A primeira delas se relaciona a validação do material com análises comparativas em laboratório. $O$ kit foi calibrado com os equipamentos laboratoriais para garantir uma maior confiabilidade dos dados que foram produzidos pelos alunos. Devido a grande quantidade de indicadores da qualidade da água, foram priorizados no kit inicialmente: pH, Amônia, Turbidez, Cloro e Cor. A segunda etapa corresponde a utilização em campo dos kits produzidos pelos alunos.

Para a segunda etapa foi prevista a seguinte sequência de trabalho:

- Discussão sobre os indicadores de qualidade da água;

- Produção do kit pelos alunos;

- Saída de campo para coleta de amostras;

- Análise das amostras utilizando o kit produzido

- $3^{a}$ Coleta de dados: Sistematização dos dados obtidos com as amostras e entrevista em grupo sobre as dificuldades e benefícios do uso do kit produzido. 
Os dados coletados com os alunos nas entrevistas foram utilizados para discutir a importância do uso de materiais didáticos para a análise ambiental e as dificuldades da produção desses materiais.

\subsubsection{Aplicação do Modelo PEIR}

Após a produção da imagem de satélite com os elementos encontrados no entorno escolar e dos kits de análise da água, os alunos sistematizaram os dados obtidos para aplicar o Modelo PEIR. Com essa etapa os alunos relacionaram os problemas encontrados com os impactos que eles podem gerar, os responsáveis e as possíveis respostas para esses aspectos levantados

Neste momento da pesquisa foram organizadas as seguintes etapas:

- Discussão com os alunos sobre o Modelo PEIR;

- Sistematização dos dados obtidos na imagem de satélite para elaboração do quadro resumo;

- Produção do quadro, seguindo o Modelo PEIR;

- Discussão sobre os quadros produzidos;

- Reelaboração dos quadros

- $4^{a}$ coleta de dados: documentos produzidos pelos alunos, no caso, os Modelos PEIR produzidos.

A coleta de dados utiliza como instrumento os documentos produzidos pelos alunos durante as atividades previstas. Os dados obtidos foram categorizados novamente segundo o Modelo PEIR. A discussão dos dados está centrada na comparação dos dados obtidos na primeira e terceira coletas.

\subsubsection{Construção dos Indicadores de Desenvolvimento Sustentável}


A última etapa de trabalho propõe que os alunos, após a sistematização dos dados, se mobilizem para a produção de indicadores de desenvolvimento sustentável sobre o entorno escolar. Espera-se que além da análise do ambiente, eles sejam capazes de propor situações que visem a melhoria do bairro onde a escola está inserida e essa proposta precisa estar associada a criação de indicadores que forneçam informações que facilitem a tomada de decisões.

Com esse objetivo, esta etapa está dividida em quatro momentos:

- Discussão com os alunos sobre os Indicadores de Desenvolvimento Sustentável;

- Discussão sobre os Princípios de Bellagio;

- $5^{a}$ Coleta de dados: Construção em grupo de Indicadores de Desenvolvimento Sustentável para o bairro;

- $6^{a}$ Coleta de dados: questionário final com o objetivo de sistematizar os conhecimentos desenvolvidos pelos alunos após as atividades propostas.

Para a análise dos dados obtidos foram utilizados a categorização dos indicadores segundo os Princípios de Bellagio, de forma mais específica os dados foram sistematizados e analisados buscando descobrir se eles "atendem", "atendem parcialmente" ou "não atendem" os princípios propostos por Bellagio (ISD, 2000). 


\section{RESULTADOS E DISCUSSÕES}

Com a intenção de facilitar o entendimento das ações realizadas e suas reflexões, este capítulo está subdividido em dois momentos. Um primeiro, com foco na construção do produto, qual seja, a cartilha sobre a análise do entorno escolar e das aulas desenvolvidas com os alunos. O segundo momento, apresenta os resultados obtidos durante as aulas e suas reflexões segundo os autores já anteriormente citados.

\subsection{O processo de construção das aulas e do kit de análise da água}

Durante o $2^{\circ}$ semestre de 2017 e de 2018 foram desenvolvidas as atividades propostas para a pesquisa. Dessa forma, por meio de um projeto intitulado de "Projeto Paraisolândia", de iniciativa dos professores e gestores da EMEB Prof. Erotides de Campos, localizada no bairro Paraisolândia em Charqueada - SP, desenvolveram-se as seguintes práticas:

1- Pesquisa de campo com os alunos no bairro em que a escola está inserida (Figuras 4, 5 e 6), com o objetivo de levantar dados sobre:

a. Produção econômica

i. Comércio

ii. Indústria

iii. Pequenos comerciantes e produtores

b. Elementos sociais e naturais

i. Áreas naturais (rios e árvores)

ii. Espaços públicos

iii. Espaços culturais e religiosos

c. Problemas ambientais

i. Esgoto

ii. Lixo

iii. Desmatamento 


\section{d. Transformações nas paisagens}

i. Comparação de fotografias

ii. Relato de moradores

Figura 4: Aula de campo realizada no entorno escolar

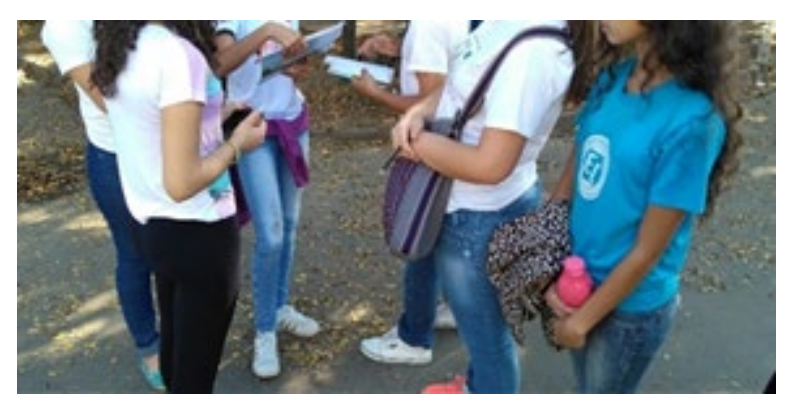

Fonte: Arquivo do autor

Figura 5: Anotações dos dados encontrados pelos alunos em uma folha de controle.

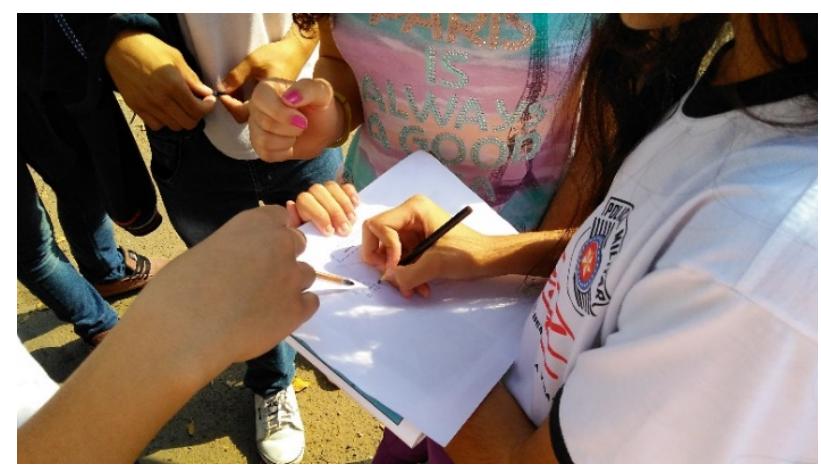

Fonte: Arquivo do autor

Figura 6: Rio Paraisolândia próximo ao entorno escolar.

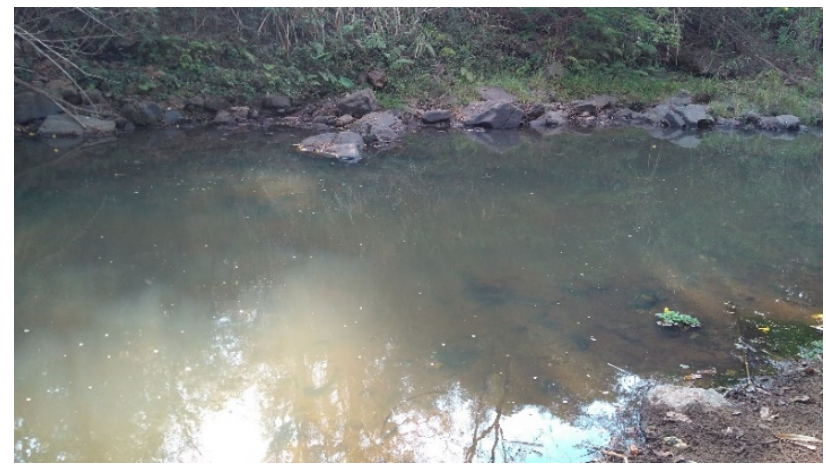

Fonte: Arquivo do autor 
2- Em um segundo momento ocorreu a construção de ícones e legendas para a imagem de satélite com os elementos encontrados no entorno escolar com os dados obtidos na pesquisa de campo (Figuras 7 e 8 ).

Figura 7: Construção da imagem de satélite com os dados obtidos na aula de campo.

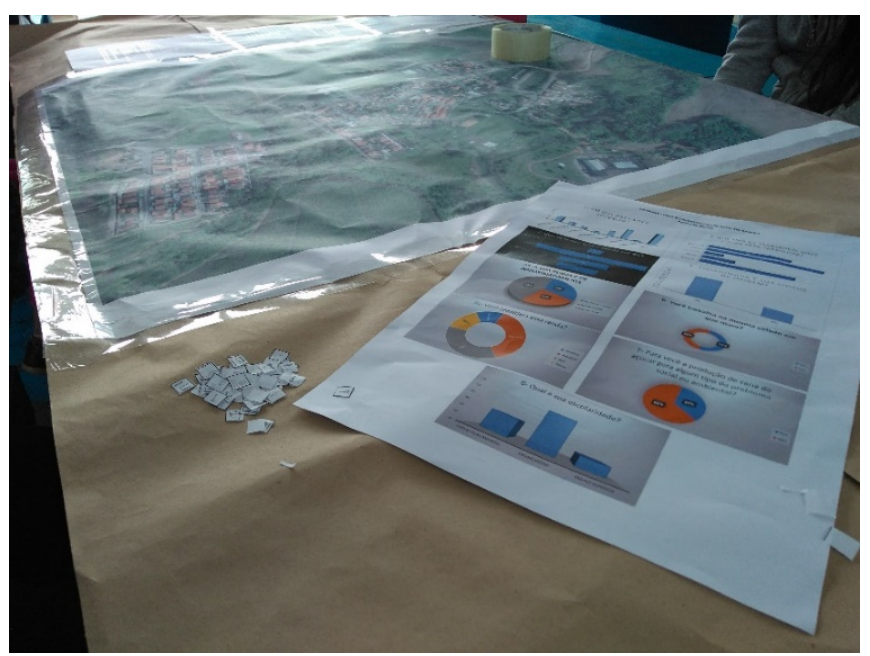

Fonte: Arquivo do autor

Figura 8: Inserção das legendas na imagem de satélite sobre o bairro.

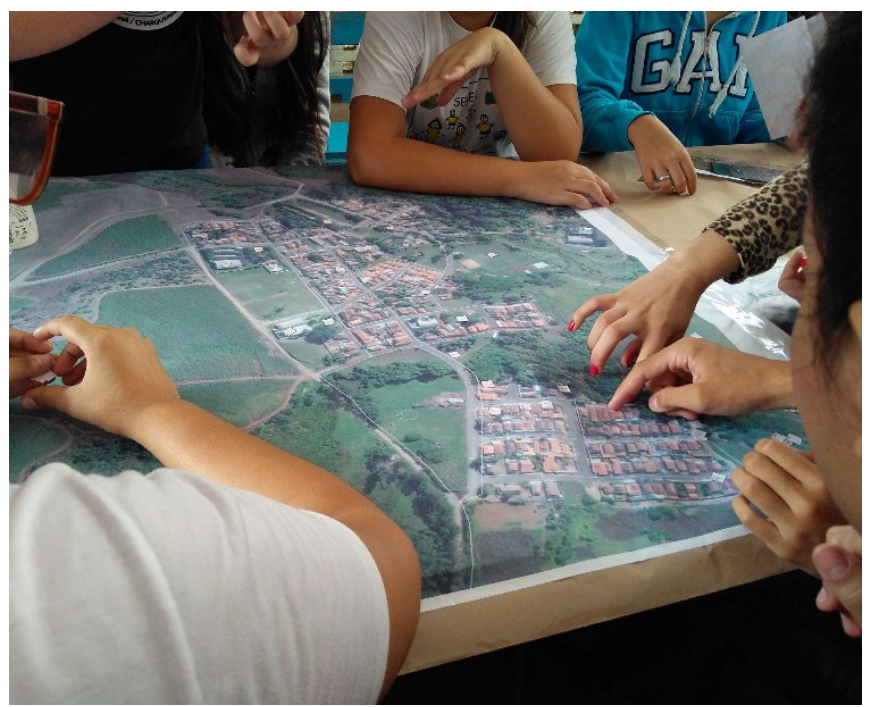

Fonte: Arquivo do autor 
3- Após o levantamento e produção das legendas os alunos produziram uma imagem de satélite com as informações coletas (Figura 9);

Figura 9: Imagem de satélite apresentação aos demais alunos, professores, gestores e pais/responsáveis.

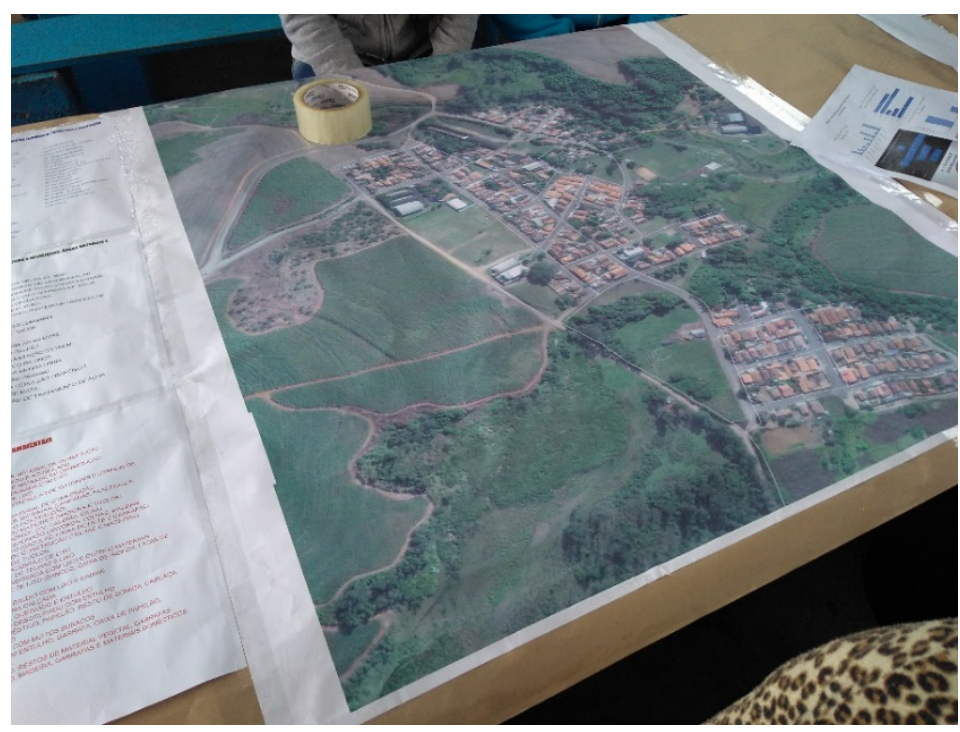

Fonte: Arquivo do autor

4- Como durante o levantamento os alunos ficaram interessados por questões relacionadas a água, foi produzido o Kit de baixo custo para análise da água (Figuras 10, 11 e 12).

Figura 10: Produção do local de armazenamento dos indicadores do kit de análise da água.

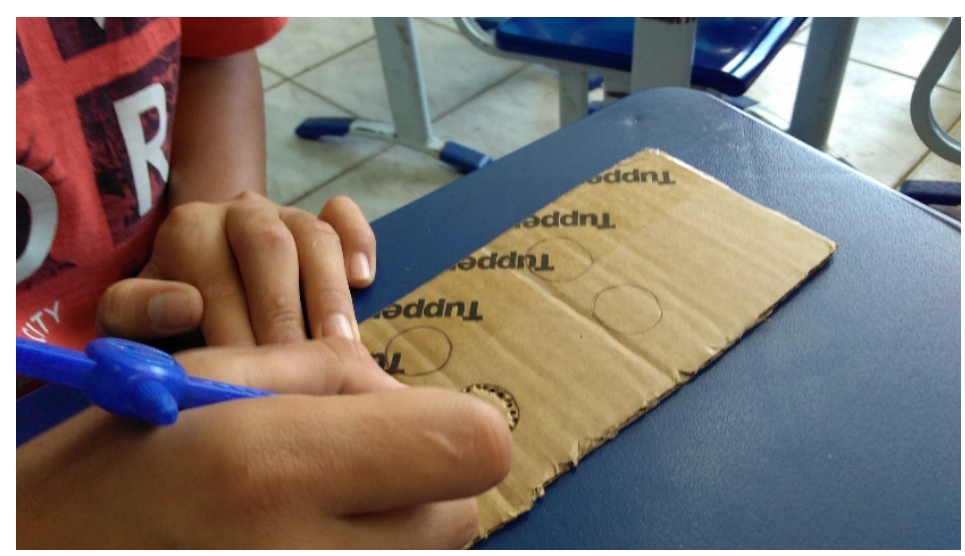

Fonte: Arquivo do autor 
Figura 11: Produção do local de armazenamento das amostras do kit de análise da água.

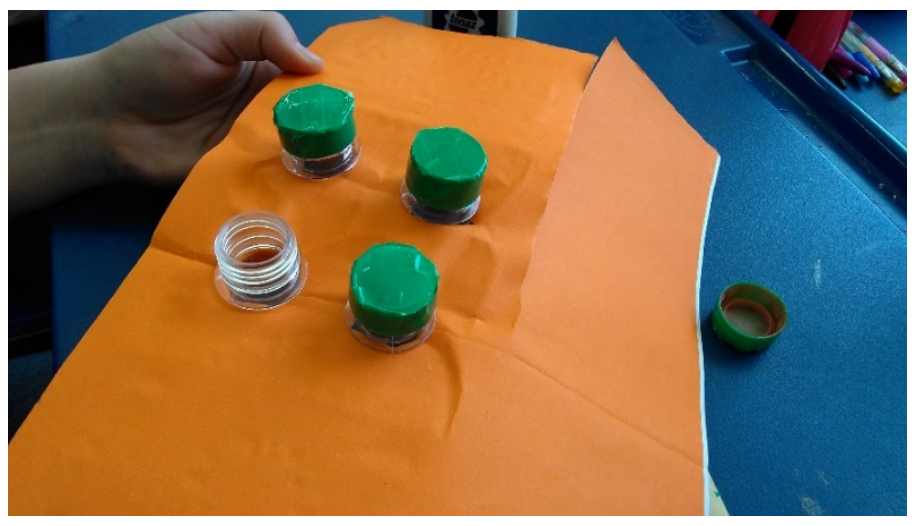

Fonte: Arquivo do autor

Figura 12: Kit para análise da água.

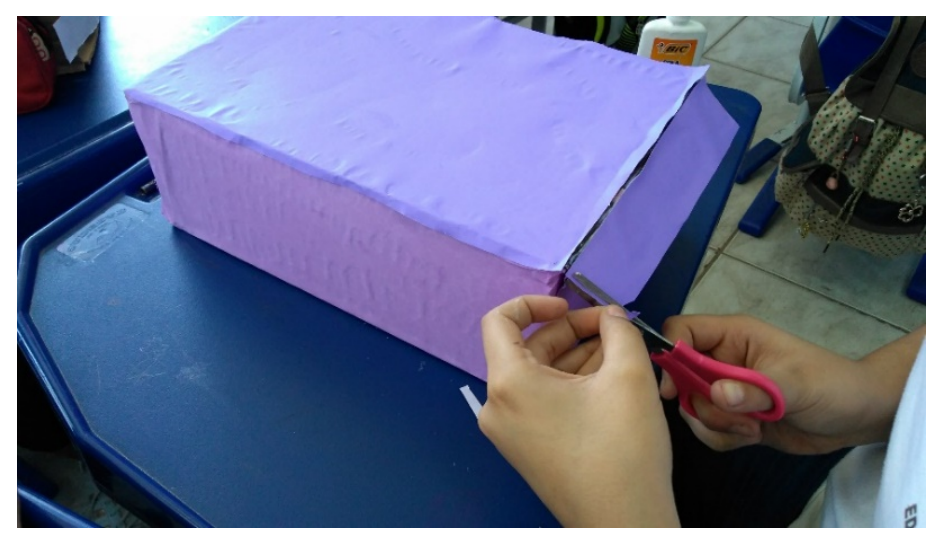

Fonte: Arquivo do autor

5- Com o kit em mãos os alunos foram levados a realizar a análise da água do Rio Paraisolândia que se localiza próximo a escola e anotaram os resultados em uma folha (Figuras 13 e 14). 
Figura 13: Alunos coletando água para ser analisada com o kit

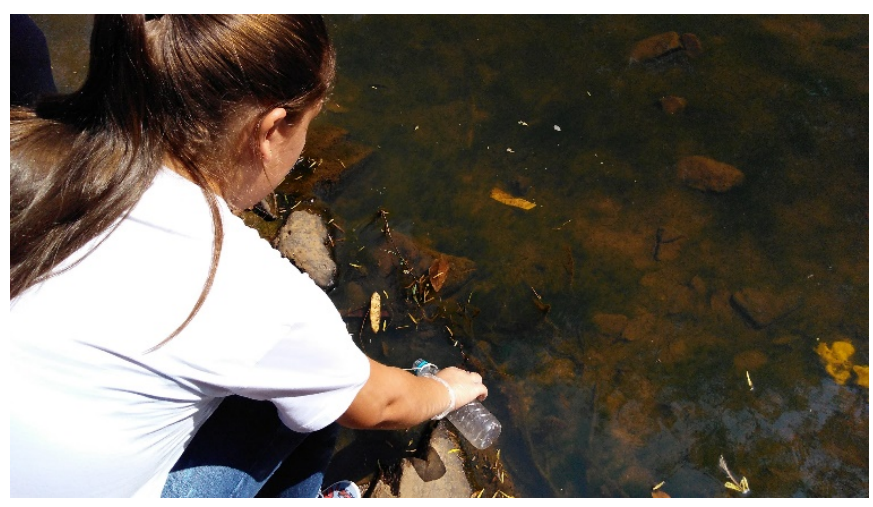

Fonte: Arquivo do autor

Figura 14: Alunos realizando a análise da água com o kit.

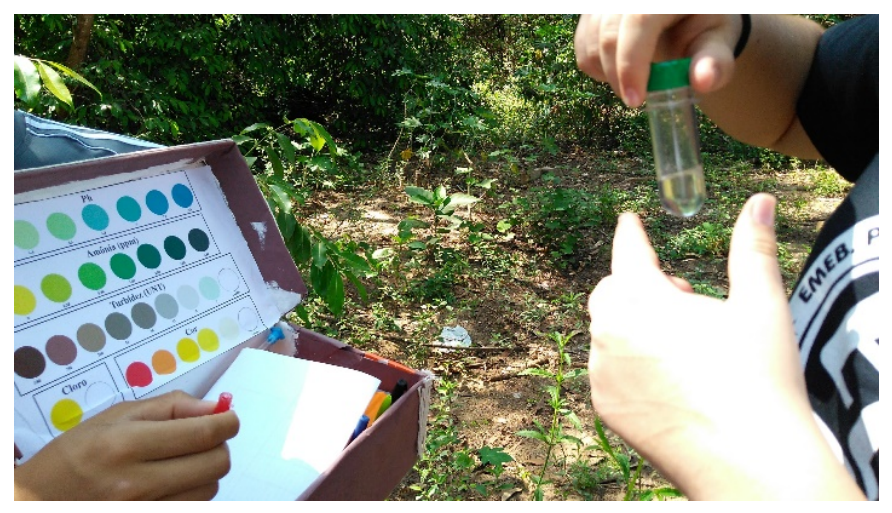

Fonte: Arquivo do autor

6- Para finalizar as atividades, foram realizadas discussões sobre os temas apresentados, como o levantamento de dados, os modelos de análise ambiental e os problemas socioambientais presentes no bairro. As discussões foram anotadas em diário de campo e escritas em um questionário para posterior análise.

Os dados preliminares obtidos com o questionário apontam que as atividades desenvolvidas contribuem para o conhecimento dos alunos quanto aos recursos naturais, sociais e econômicos existentes no bairro e principalmente favorece a identificação dos problemas ambientais mais frequentes. Outro ponto destacado pelos 
alunos diz respeito a valorização do espaço, a preservação do ambiente, no caso, o rio, e as mudanças ocorridas no bairro que as atividades proporcionam.

Com relação ao kit de água pode-se notar que durante a sua construção os alunos esbarram em algumas dificuldades relacionadas a falta de habilidades para sua produção como, por exemplo, o recorte das folhas para a decoração do kit.

Com as discussões sobre os modelos de análise dos indicadores de desenvolvimento sustentável (Modelo PEIR) observa-se que os alunos apresentam uma fácil compreensão da Pressão-Estado-Impactos-Resposta das condições ambientais existentes no bairro em que a escola está inserida. Entre as relações, por exemplo, citadas pelos alunos pode-se exemplificar as respostas obtidas e registradas no Quadro 1.

Quadro 1: Exemplo do Modelo PEIR criado pelos alunos durante as atividades.

\begin{tabular}{|c|c|c|c|}
\hline PRESSÃO & ESTADO & IMPACTO & RESPOSTAS \\
\hline $\begin{array}{c}\text { Aumento do } \\
\text { consumo geral de } \\
\text { recursos, falta de } \\
\text { locais para } \\
\text { descarte de } \\
\text { materiais }\end{array}$ & $\begin{array}{c}\text { Acúmulo de } \\
\text { material no bairro }\end{array}$ & $\begin{array}{c}\text { Enchentes, } \\
\text { alagamentos, } \\
\text { doenças como a } \\
\text { dengue, } \\
\text { proliferação de } \\
\text { animais } \\
\text { peçonhentos }\end{array}$ & $\begin{array}{c}\text { Redução do } \\
\text { descarte de lixo, } \\
\text { campanhas } \\
\text { educacionais }\end{array}$ \\
\hline $\begin{array}{c}\text { Despejo incorreto } \\
\text { de lixo e esgoto } \\
\text { no rio }\end{array}$ & Rio poluído & $\begin{array}{c}\text { Perda da } \\
\text { biodiversidade, } \\
\text { doenças }\end{array}$ & $\begin{array}{c}\text { Campanhas } \\
\text { educacionais e } \\
\text { multas }\end{array}$ \\
\hline $\begin{array}{c}\text { Excesso de } \\
\text { caminhões, } \\
\text { material de baixa } \\
\text { qualidade }\end{array}$ & $\begin{array}{c}\text { Asfalto quebrado, } \\
\text { buracos na rua }\end{array}$ & $\begin{array}{c}\text { Causa acidentes, } \\
\text { estragam os } \\
\text { automóveis }\end{array}$ & $\begin{array}{c}\text { Melhoria no } \\
\text { asfalto, redução } \\
\text { do consumo de } \\
\text { combustível }\end{array}$ \\
\hline
\end{tabular}

Elaborado pelo autor, 2019.

Dessa forma pode-se dizer que a construção de uma sequência de atividades que envolvam a análise do ambiente próximo a escola, a construção de um kit para 
análise da água e a discussão sobre os modelos de análise ambiental, contribuem para uma melhor compreensão dos alunos sobre os problemas ambientais e sua relação com as ações humanas presentes na sociedade.

\subsection{Análise dos dados obtidos durante a pesquisa}

\subsubsection{Questionário Inicial}

Neste primeiro questionário aplicado aos alunos, logo no início de desenvolvimento da pesquisa, tinha-se por objetivo conhecer de que forma a educação ambiental está presente no contexto escolar, bem como quem são os professores que mais se envolvem nessas ações e quais os recursos didáticos que se utilizam. Além disso, buscou-se fomentar um breve questionamento sobre o que seria as Ciências Ambientais e quais seriam os principais problemas presentes nas áreas próximas a escola. Nesta primeira etapa, a turma presente e que respondeu ao questionário era formada por 26 alunos do $8^{\circ}$ ano.

Para a primeira questão, observou-se que $84 \%$ dos alunos alegaram que são realizadas atividades de educação ambiental na escola. Elas envolvem temas como: problemas ambientais (poluição, lixo, desmatamento), preservação ambiental, reciclagem e a memórias do bairro. Ainda nesta questão alguns alunos descrevem que são utilizadas também como recursos, documentários, cartazes e aulas de campo na cidade e no bairro em que a escola está inserida.

Outro ponto analisado revela que grande parte das atividades estão concentradas apenas em um professor ou disciplina, neste caso, a de geografia. Apenas quatro participantes apontam a realização de atividades em outras aulas, como nas de ciências, educação física, português e matemática. Essas aulas costumam acontecer, segundo $73 \%$ dos alunos, dentro do município onde a escola está inserida, sendo realizadas nas áreas próximas ou dentro da escola. Nenhum aluno apontou que essas atividades são realizadas fora do município.

Os recursos didáticos utilizados pelos professores para desenvolver as atividades de educação ambiental, se limitam a quatro, sendo eles: livros (50\% do 
participante), mapas $(42,3 \%)$, lousa e giz $(30,8)$ e, computador $(26,9)$. Não foi apontado por nenhum aluno o uso de jogos, aplicativos, dinâmicas, filmes ou aulas de campo, nesta questão.

Não há uma definição comum entre os alunos sobre qual seria as Ciências Ambientais, mas no geral eles descrevem que ela pode ser entendida como uma Ciência que estuda o ambiente, seus problemas e modificações, sendo também responsável por ensinar a proteger o ambiente e os animais. Um dos alunos escreve que "são coisas que nos ajudam a conhecer o local onde vivemos e nos ajuda a saber mais sobre o mundo", outro diz que ela "estuda o ambiente como rios, água e ar e a ver se tem algo errado, se sim como tratar". Dentro das respostas, porém, não se encontra uma menção sobre o caráter interdisciplinar dessa busca por soluções ambientais, ou sua relação com as questões econômicas, sociais, históricas e culturais.

Quando questionados sobre os principais problemas presentes no bairro, os alunos apontaram que os principais estão relacionados ao Lixo (73\%), Poluição do Rio $(34,6 \%)$, Desmatamento (11,5\%), Queimadas (11,5\%) e Entulho (11,5\%). Também foram indicados a poeira, poluição do ar, falta de reciclagem e o abandono de prédios históricos. Como possíveis causas são citadas o desenvolvimento do bairro e a falta de consciência das pessoas, além disso, esses problemas geram outros, como a transmissão de doenças devido aos insertos e animais que ficam nesses ambientes.

\subsubsection{Saída de Campo}

Após a aula de campo, que percorreu as ruas do bairro onde a escola está inserida, os alunos foram questionados sobre a atividade. As respostas apresentadas foram categorizadas em cinco principais grupos, sendo eles: falas sobre economia, ambiente, social, história e cultura.

Sobre os elementos econômicos do bairro, nota-se que alguns alunos desconheciam grande parte do comércio local ou dos problemas ambientais presentes no bairro. Segundo um aluno "a gente pode aprofundar os problemas ambientais do bairro e conhecer novos lugares, coisas que nem sabia que tinha no bairro, muitos comércios". Foram encontradas, padarias, quitandas, açougues, cabeleireiros, 
papelarias, bares entre outros estabelecimentos que tem um impacto sobre o cotidiano dos moradores, no total foram identificados ao todo 25 pontos de comércio.

Por se tratar de um bairro afastado, um aluno descreve que "o bom de ter aqui é que não precisamos ir lá em Charqueada para procurar uma carne, tudo fica lá praticamente, sair daqui pra ir em Charqueada, pra ver algumas coisas. Quando o povo começar a conhecer aqui, surge algo de última hora, tem o comércio aqui, fica mais fácil". Nessa perspectiva, entende-se que o comércio local tem grande importância para as pessoas do bairro, mesmo que não apresente as mesmas características do centro da cidade. Isso se deve, em linhas gerais, pela distância entre o bairro onde a escola está e o centro da cidade, cerca de $10 \mathrm{~km}$.

No aspecto cultural, os alunos apontaram apenas a presença de igrejas, ao todo são seis diferentes locais relacionados ao cristianismo católico e protestante. Nesta mesma área, a dimensão social foi apresentada pelos alunos como aquela envolvendo a presença de escolas, campos, praças, academias, hortas, posto de saúde e um núcleo de apoio pedagógico (NAPE). Na dimensão histórica, foram observadas construções do século XIX, como a antiga Estação de Trem e a Usina São Francisco, produtora de açúcar na época. Para um aluno "não temos muitos pontos históricos, porque está tudo destruído", mais tarde, no decorrer das atividades, nota-se uma preocupação durante a produção dos indicadores de que esses locais históricos possam ser resgatados como pontos turísticos do bairro.

Durante o percurso realizado pelos alunos, diversos foram os problemas ambientais encontrados por eles, desde a presença de lixo e entulho nas ruas, até a poluição do rio e de suas margens. Ao todo são 19 locais no bairro que apresentam problemas e que são discutidos em outros momentos das atividades. Como destaca o participante 33, "descemos até o rio e tinha uma placa, "proibido jogar lixo e jogar entulho" e lá tinha um monte de lixo", completa apontando que "o que causa isso é a falta de responsabilidade das pessoas, de saber que é errado fazer isso". Outro participante destaca que "notamos que nos bueiros tinha bastante lixo e se eles entupirem pode causar enchentes que é uma coisa muito ruim". 


\subsubsection{Modelo PEIR}

Como forma de aprofundar a discussão sobre os elementos encontrados na saída de campo, os participantes produziram individualmente um Modelo PEIR, sendo observados a Pressão, o Estado, os Impactos e as Respostas. No Quadro 2 está apresentada a categorização das respostas para uma posterior discussão, sendo definidas de acordo com a frequência que os temas foram levantados pelos alunos.

Quadro 2: Categorias do Modelo PEIR

\begin{tabular}{|c|c|c|c|}
\hline PRESSÃO & ESTADO & IMPACTO & RESPOSTA \\
\hline Cultura & Cultura & Econômico & Manutenção das \\
Infraestrutura & Social & Social & áreas \\
Educação & História & Ambiental & Pesquisa \\
Conservação & Economia & & Tecnologia \\
Consumo & Ambiente & & Penalização \\
Desenvolvimento & & & Educação \\
& & & Novas áreas \\
\hline
\end{tabular}

Elaborado pelo autor, 2019.

Para $25 \%$ dos participantes a pressão que gera mudanças no estado do ambiente está relacionada a conservação dos locais presentes no bairro. Dentro desta categoria, tem-se a ideia de que o fato de um local não ser bem cuidado, gera nas pessoas um motivo para que ele possa continuar a ser degradado. A mesma quantidade de participantes cita que o consumo das pessoas e por consequência a produção de lixo e entulho se torna a condição para que esse material se acumule nas ruas do bairro.

A infraestrutura também foi apontada com um dos fatores responsáveis pelo estado do ambiente estudado, sendo que, para $20 \%$ dos alunos, a falta de estações de tratamento de esgoto ou de depósitos adequados para o lixo e entulho são condições que fazem com que as pessoas joguem esses materiais em locais não corretos. A educação aparece em $15 \%$ das respostas dos alunos, segundo eles, a falta de consciência e de discussões sobre o assunto com as pessoas do bairro é um fator determinante no estado do ambiente. 
O crescimento urbano do bairro e a cultura das pessoas, que pouco se preocupam com o ambiente, respectivamente com $10 \%$ e $5 \%$, presentes nas respostas dos participantes, são entendidas como fatores relacionados aos crescentes problemas ambientais presentes no entorno escolar estudado.

Apesar de a aula de campo apresentar diferentes dimensões para análise do entorno escolar, segundo $74,1 \%$ dos participantes os maiores problemas encontrados se referem às questões ambientais. As dimensões sociais, históricas e culturais são pouco mencionadas e, a econômica não aparece em nenhuma das respostas. $\mathrm{O}$ acumulo de materiais de construção, lixo, a falta de arborização, o mau cheiro, a poluição do rio e do ar, são os elementos que mais se destacam na dimensão ambiental. A má conservação dos espaços históricos e públicos do bairro demonstram a preocupação de alguns alunos com a falta de valorização desses espaços, que segundo eles poderiam ser mais bem utilizados.

Dentro do Modelo PEIR realizado pelos alunos, nota-se uma grande relação entre os Estados do ambiente e seu posterior Impacto. A análise revela que para $64,3 \%$ dos participantes as mudanças nos estados geram impactos nas esferas sociais, sendo responsável pelo desenvolvimento de doenças na população local e o aparecimento de insetos e animais peçonhentos. Os impactos ambientais são descritos como sendo aqueles que geram a morte de animais, a poluição do ambiente, o aquecimento global e a falta de frutos, sendo citados por $28,6 \%$ dos participantes. Uma quantidade bem pequena de alunos demonstrou uma preocupação com os impactos econômicos dos problemas encontrados no bairro, apesar de ser um ponto importante quando se fala de desenvolvimento sustentável.

Como se trata de uma atividade que busca uma possível solução para os problemas encontrados, as Respostas dos alunos sobre o que deveria ser feito envolvem quatro principais categorias: manutenção das áreas, Educação e, Criação de Novas Áreas (todas com 22,6\% das respostas) e a penalização dos munícipes (19,4\%). São citadas a necessidade de "aumentar os cuidados no bairro", "melhorar a captação de esgoto", "reflorestamento", a "reforma dos locais", a "construção de locais corretos para o descarte do entulho", a "criação de pontos para a população jogar o lixo" e a implementação de "mais lixeiras no bairro". Com relação a educação, são esperadas 
ações que envolvam campanhas de conscientização, divulgação, investimentos e maiores responsabilidades da população, sendo que a penalização deve ocorrer com a aplicação de multas para quem "joga lixo ou entulho" no bairro.

Chama a atenção para o fato da pesquisa e da tecnologia, respectivamente, $9,7 \%$ e $3,2 \%$ das respostas, serem pouco citadas, se concentrando no desenvolvimento de novos carros e pesquisas por parte da prefeitura municipal sobre a condição do bairro em que a escola está inserida.

\subsubsection{Indicadores}

A análise dos indicadores produzidos pelos alunos foi realizada utilizando-se os Princípios de Bellagio (IISD, 200). Como os participantes são do ensino fundamental, foi necessária uma adaptação dos princípios e sua seleção, sendo utilizados os de números um, dois, quatro, cinco e dez. Sua categorização foi feita em "Atende", "Atende Parcialmente", "Não Atende". No total foram analisados 100 indicadores produzidos, onde destes 60 não puderam ser classificados, os outros 40, foram categorizados dentro dos cinco princípios já apontados, gerando um total de 200 análises.

Princípio Um: Guia de Visão e Metas

Neste princípio, como critérios foram utilizados a clareza do indicador e sua relação com o desenvolvimento sustentável. Sendo que $75 \%$ dos indicadores apresentam uma clareza quanto aos seus objetivos e estão enquadrados dentro de uma busca por melhorias nas dimensões sociais, econômicas e ambientais. Apenas $10 \%$ não atendem a esse princípio. 
Princípio Dois: Perspectiva Holística

Uma das dificuldades encontradas nos indicadores produzidos pelos alunos está na integração dos elementos presentes em diferentes dimensões do desenvolvimento sustentável. Observa-se que $47,5 \%$ dos indicadores não atendem a integração das dimensões sociais, ambientais e econômicas. Em 42,5\% deles, foi possível notar uma integração em apenas duas dimensões, sendo mais recorrentes aquelas ligadas as dimensões sociais e ambientais. Apenas $10 \%$ dos indicadores produzidos integram todas as dimensões.

Princípio Quatro: Escopo adequado

Dentro dos princípios de Bellagio há uma necessidade de que os indicadores sejam pensados a fim de abranger uma escala de tempo que avalie os elementos em curtos e longos períodos, sendo observados aspectos locais e globais. No caso da atividade produzida, os indicadores propostos pelos alunos deveriam apresentar uma indicação de tempo em que o indicador deva ser verificado, sendo principalmente aferido na escala local. Dessa forma, $67,5 \%$ dos indicadores não apresentam de forma clara a escala de tempo em que o indicador deva ser verificado e $25 \%$ se referem a um período que varia de meses a anos.

Princípio Cinco: Foco prático

Um dos aspectos que mais se nota nos indicadores produzidos pelos alunos diz respeito a praticidade de verificação e acompanhamento dos elementos estudados. Em $67,5 \%$ dos indicadores há um foco prático, sendo possíveis de implementação e acompanhamento no contexto escolar, $17,5 \%$ atendem parcialmente, sendo necessário 
uma definição melhor dos parâmetros a serem utilizados e 15\% não possuem foco prático, pois são de difícil verificação.

Princípio Dez: Capacidade Institucional

Os indicadores produzidos pelos alunos têm a preocupação de poderem ser utilizados para o acompanhamento das ações realizadas no bairro ou até no município. $85 \%$ deles atendem a possibilidade de serem institucionalizados, sendo usados como forma de acompanhamento por diferentes níveis organizacionais da sociedade, desde a comunidade local aos governantes municipais.

\subsubsection{Integração Modelo PEIR e Indicadores}

$\mathrm{Na}$ entrevista final com os alunos o objetivo foi levantar dados sobre a opinião deles sobre a importância do Modelo PEIR e dos Indicadores. As categorias foram definidas a posteriori sendo subdivididas em: Modelo PEIR- Conhecer e resolver os problemas, Facilidade de entendimento, Integração das dimensões e; Indicadores: Auxiliam na tomada de decisões, Fornecem Informações.

Para $70 \%$ dos participantes o Modelo PEIR desenvolvido nas atividades favorece o conhecimento sobre os problemas presentes no entorno escolar e auxiliam na tarefa de resolvê-los. Segundo o aluno 4, "você pode ter uma noção dos problemas que estão principalmente afetando a cidade ou o seu bairro", outro (participante) afirma que "ele ajuda você a pensar um pouco mais sobre o que está acontecendo no bairro". Neste mesmo grupo, a facilidade de entendimento foi apontada por $20 \%$ dos participantes, sendo considerado mais fácil organizar as informações e importante por ser "simples e eficaz". Contudo, apesar de as atividades envolverem a integração das diferentes dimensões, apenas $10 \%$ dos participantes apontaram esse elemento como sendo um dos pontos importantes do uso do Modelo PEIR. 
Com relação aos Indicadores, $60 \%$ dos entrevistados apontaram que ele auxilia na tomada de decisões, além disso, para $40 \%$ dos participantes ele fornece informações sobre a condição do local. Essas duas citações demonstram que os alunos compreendem que os indicadores são recursos que se tornam de grande importância com relação ao fornecimento de dados sobre as condições do ambiente e posteriormente, com esses dados, facilita a tomada de decisões pelas pessoas que desejam realizar mudanças nesses locais.

\subsection{A construção do produto: A cartilha como guia para a análise do entorno escolar pelos alunos}

A construção do produto foi realizada durante e após a aplicação das atividades com os alunos. Em um primeiro momento foi apresentada uma cartilha que deveria ser analisada pelos alunos durante as ações executadas na pesquisa, sendo que as observações apontadas por eles foram anotadas em um diário de bordo, para que fossem implementadas na versão final. A versão final do produto apresenta a seguinte organização:

Quadro 3: Capítulos e temas abordados no produto

\begin{tabular}{|c|l|}
\hline \multicolumn{1}{|c|}{ Capítulo } & \multicolumn{1}{|c|}{ Temas abordados } \\
\hline $\begin{array}{c}\text { Introdução } \\
\text { sobre o entorno escolar }\end{array}$ & $\begin{array}{l}\text { A organização de uma aula de campo e a } \\
\text { análise do entorno escolar a partir das } \\
\text { dimensões sociais, históricas, culturais, } \\
\text { econômicas e ambientais }\end{array}$ \\
\hline $\begin{array}{l}\text { 2- Organização das informações } \\
\text { segundo o Modelo PEIR }\end{array}$ & $\begin{array}{l}\text { Produzindo uma análise do entorno } \\
\text { escolar segundo o Modelo PEIR }\end{array}$ \\
\hline 3- Produção do Kit de análise da águaa & $\begin{array}{l}\text { Etapas de construção e uso do kit de } \\
\text { análise da água }\end{array}$ \\
\hline 4- Construção dos Indicadores de & \begin{tabular}{l} 
Como construir indicadores de \\
\hline
\end{tabular}
\end{tabular}




\begin{tabular}{|c|l|}
\hline Desenvolvimento Sustentável & $\begin{array}{l}\text { desenvolvimento sustentável a partir da } \\
\text { análise do entorno escolar e do Modelo } \\
\text { PEIR }\end{array}$ \\
\hline $\begin{array}{r}\text { 5- Apresentação dos resultados } \\
\text { obtidos através das atividades }\end{array}$ & $\begin{array}{l}\text { Organização da divulgação dos dados e } \\
\text { materiais produzidos durante as } \\
\text { atividades }\end{array}$ \\
\hline Referências Bibliográficas & \\
\hline Anexos & \\
\hline
\end{tabular}

Elaborado pelo autor, 2019. 


\section{CONSIDERAÇÕES FINAIS}

A pesquisa buscou responder a duas perguntas durante seu desenvolvimento, sendo elas: Como a Educação Ambiental e o Ensino das Ciências Ambientais está inserida na escola onde foi realizada a pesquisa e quais são seus principais recursos didáticos utilizados para seu desenvolvimento? Qual o impacto na aprendizagem sobre questões ambientais que o uso dos recursos didáticos atrelados aos indicadores ambientais e modelos de análise da sustentabilidade podem gerar?

Para a primeira questão, observou-se que no ambiente escolar estudado, ainda se faz presente na Educação Ambiental o uso de recursos didáticos tradicionais, como o livro didático e a lousa. Além disso, percebe-se que as atividades desenvolvidas sobre esse tema se concentram sempre em um professor, o que segundo as referências utilizadas se mostram ineficazes quando se busca uma melhor compreensão e imersão dos alunos na complexidade que a temática ambiental envolve.

Com relação a utilização do Modelo PEIR e dos Indicadores de Desenvolvimento Sustentável para o desenvolvimento de aprendizagens relativas as questões ambientais presentes no entorno escolar, a pesquisa demonstra que sua utilização no ensino fundamental II é de grande importância para que o aluno consiga associar elementos presentes nas diferentes dimensões, integrando questões sociais, históricas, econômicas, culturais e ambientais.

Esse uso do Modelo PEIR e dos Indicadores deve ser acompanhado de práticas pedagógicas que se utilizem de diferentes recursos didáticos para seu desenvolvimento, sendo principalmente as aulas de campo um dos recursos de maior impacto para sua compreensão por parte dos alunos. Além disso, a construção do kit de análise da água contribui para que os alunos entendam que os Indicadores necessitam de um ótimo planejamento e de parâmetros bem definidos para que possa ser efetivado, bem como se busque uma integração com os demais setores da sociedade, que os dados sejam apresentados de forma clara e transparente.

Com relação ao objetivo principal do trabalho, pode-se dizer que as situações de ensino que busquem investigar, analisar e a construir indicadores com os alunos sobre 
as áreas próximas a escola podem ser de grande relevância para o ensino das ciências ambientais, contribuindo também para uma visão interdisciplinar dos alunos sobre o complexo contexto ambiental presentes na sociedade.

O trabalho também buscou com os objetivos específicos uma relação do uso de recursos didáticos para o apontamento dos problemas ambientais presentes no entorno escolar. Entende-se que o uso das aulas de campo, de imagens de satélite, de mapas, de instrumentos como o kit de análise da água, o Modelo PEIR e os Indicadores de Desenvolvimento Sustentável, ampliam o conjunto de recursos a serem utilizados nas aulas para a construção de alunos críticos e conscientes sobre sua relevância na busca por soluções dos problemas encontrados.

Apesar dos questionários apresentados demonstrarem que no ambiente escolar ainda prevalece o uso dos livros didáticos para a educação ambiental, a cartilha elaborada como produto educacional desta pesquisa, apresenta como descrito anteriormente, diferentes atividades para que os professores possam abordar o tema em sala de aula, podendo contribuir para a construção de formas participativas dos alunos na tomada de decisões sobre a comunidade onde estão inseridos.

\subsection{Sugestões para trabalhos futuros}

O trabalho com os Indicadores de Desenvolvimento Sustentável no ambiente escolar se mostrou um tema de pesquisa que apresenta grandes possibilidades de desenvolvimento de novas práticas escolares em diferentes níveis de ensino. Como sugestão para trabalhos futuros tem-se como recorte da presente pesquisa a necessidade de discutir e desenvolver formas de construir e integrar esses indicadores aos demais setores da sociedade, enfatizando a necessidade de integrar, dentro das políticas públicas, os alunos da educação básica para que se possa em um futuro, fazer com que eles já estejam familiarizados com esses elementos que são tão importantes para o planejamento e desenvolvimento local e global. 


\section{REFERÊNCIAS BIBLIOGRÁFICAS}

BAIÃO, C. F. P.; BATISTA, G. T. Avaliação de bacia hidrográfica por alunos do Ensino Fundamental: contribuições ao ensino dos recursos hídricos, Revista Ambiente \& Água, v. 11, 2016.

BERDNARZ, S. W. Geographic information systems: A tool to support geography and environmental education? Texas: GeoJournal, 2004.

CHANG, C. S.; CHEN, T. S.; HSU, W. H. The study on integrating WebQuest with mobile learning for environmental education. Computers \& Education, vol. 57, p.12281239, 2010.

FAZENDA, Ivani C. A. Integração e interdisciplinaridade no Ensino Brasileiro: efetividade ou ideologia. $6^{a}$ edição. São Paulo: Loyola, 2001.

FISCARELLI, R. B. O. Material Didático: discursos e saberes. Junqueira \& Marin: Araraquara, 2008.

FLICK, U. Uma introdução à pesquisa qualitativa. Porto Alegre: Bookman, 2004.

GOZALBO, M. E.; NÚÑEZ, L. A. Experiencias em torno al huerto ecológico como recurso didáctico y contexto de aprendizaje em la formación incial de maestros de Infantil. Revista Eureka sobre Enseãnza y Divulgación de las Ciencias, v. 13, p. 667-679, 2016.

HORTA, A. S.; ALMEIDA, L. F.; MONTEIRO, R. C. R.; MONTEIRO, D. V. A proposal of a game for education and environmental consciousness. International Association for Management of Technology, v. 10, p. 1664-1676, 2015.

IBAMA. GEO Brasil 2002: Perspectivas do Meio Ambiente no Brasil. Brasília: Edições IBAMA, 2002.

IBGE. Indicadores de desenvolvimento sustentável. Brasil 2015. Estudos e Pesquisas em Geociências, n.10, 352 p., Rio de Janeiro, 2015. 
IISD (International Institute for Sustainable Development), Bellagio Principles, Winnipeg, IISDnet, 2000. Disponível em https://www.iisd.org/pdf/bellagio.pdf

LEFF, E. Epistemologia Ambiental. 4ª edição. São Paulo: Cortez, 2007.

LEODORO, M. P. Educação científica e cultura material: os artefatos lúdicos. [Dissertação]. São Paulo: Universidade de São Paulo, 2001.

LIMA, G. F. da C. Crise ambiental, educação e cidadania: os desafios da sustentabilidade emancipatória. In: LOUREIRO, C. F. B.; LAYRARGUES, P. P.;

CASTRO, R. S. (Orgs.) Educação ambiental: repensando o espaço da cidadania. $5^{\text {a }}$ edição. São Paulo: Cortez, 2011.

LOUREIRO, C. F. B. Educação ambiental e movimentos sociais na construção da cidadania ecológica e planetária. In: LOUREIRO, C. F. B.; LAYRARGUES, P. P.; CASTRO, R. S. (Orgs.) Educação ambiental: repensando o espaço da cidadania. $5^{\text {a }}$ edição. São Paulo: Cortez, 2011.

LOUREIRO, C. F. B. Trajetórias e Fundamentos da Educação Ambiental. $4^{\mathrm{a}}$ edição. São Paulo: Cortez, 2012.

LÜDKE, M; ANDRE, M. E. D. A. Pesquisa em Educação: abordagens qualitativas. $4^{a}$ edição, São Paulo: EPU, 1986.

LUZ, F. G. Análise da utilização de material didático de ciências no ensino fundamental da rede estadual do município de Criciúma. [trabalho de conclusão de curso]. Criciúma: Universidade do Extremo Sul Catarinense, 2006. Disponível em: http://www.bib.unesc.net/biblioteca/sumario/000028/0000286F.pdf. Acesso em 30/09/2017.

MA, C. J.; SHIN, E. S. Developmente of Acid Rain Model Instrument and Its Application in Environmentel Education. Asian Journal of Atmospheric Environment, vol. 9, p. 222-227, 2015.

MADRUGA, K.; SILVEIRA, C. F. B. Can teenagers educate children concerning environmental issues? Journal of Cleaner Production, v. 11, p. 519-525, 2002. 
MALHEIROS, T. F.; PHILIPPI JR. A.; COUTINHO, S. M. V. Agenda 21 nacional e indicadores de desenvolvimento sustentável: contexto brasileiro. Revista Saúde e Sociedade, v.17, n.1, p. 7-20, São Paulo, 2008.

MATHUKRISHNAN, R.; KELLEY, J. E. Depictions of sustainability in children's books. Environment Dev Sustain, v. 19, p-955-970, 2016.

MILLER JR., T. G. Ciência Ambiental. 11ª ed. São Paulo: Thomson Learning, 2007.

MIODUSKI, K. A.; FRANCISCO, A. C. Recursos tecnológicos para a sensibilização de temas da educação ambiental. Revista Educação \& Tecnologia, n. 13, 2013.

MMA. PNIA 2012: Painel Nacional de Indicadores Ambientais. Brasília: Departamento de Gestão Estratégica, 2014.

MOREIRA, M. A. Metodologias de pesquisa em ensino. São Paulo: Livraria da Física, 2011.

PHILIPPI JR. A., PELICIONI, M. C. F. Educação ambiental: desenvolvimento de cursos e projetos. São Paulo: Signus, 2002

PILETTI, C. Didática Geral. Editora Ática: São Paulo, 2004.

PNUMA. Metodologia para elaboração de relatórios GEO Cidades. México, 2004.

QUINTAS, J. S. (orgs). Pensando e praticando a educação ambiental na gestão do meio ambiente. Brasília: IBAMA, 2006.

REIS, R. T. N.; SANTOS, R. T. F.; SANTOS, M. O.; SILVA, D. L.; SALGADO, M. F. A utilização de recursos didáticos por professores do ensino fundamental em escolas municipais de Caixias-MA. $65^{\text {a }}$ Reunião Anual da Sociedade Brasileira para o Progresso da Ciência, 2013.

SATO, M. Educação Ambiental. São Carlos: RiMa, 2003.

SAVITA, K. S.; ZAINUDDIN, N. A.; MUNANDY, N.; MEHAT, M. A mobile based apllication on environmental education for primary schoolchildren in Malaysia. Journal of Theoretical and Applied Information Techonology, v. 95, n. 22, p. 6300-6313, 2017. 
SILVA, L. H. DE A.; ZANON, L. B. A experimentação no ensino de Ciências. In: VASCONCELOS, A. L. S.; COSTA, C. H. C.; SANTANA. J. R.; CECCATTO, V. M. Importância da abordagem prática no Ensino de Biologia para a Formação de Professores. Trabalho de Conclusão de Curso em Licenciatura Plena em Ciências/Habilitação em Biologia/Química, Universidade Estadual do Ceará, Limoeiro do Norte, Ceará, 2002

SILVA, L. H. DE A.; ZANON, L. B. A experimentação no ensino de Ciências. In: SCHNETZLER, R. P.; ARAGÃO, R. M. R. Ensino de Ciências: fundamentos e abordagens. Piracicaba: CAPES/UNIMEP. 182 p. 2000.

SILVA, S. S. F.; SANTOS, J. G.; CÂNDIDO, G. A.; RAMALHO, A. M. C. Indicador de Sustentabilidade Pressão-Estado-Impacto-Resposta no diagnóstico do cenário sócio ambiental resultante dos resíduos sólidos urbanos em Cuité, PB. Revista de Administração, Contabilidade e Sustentabilidade, vol. 2, n. 3, p.76-93, 2012.

SOBRAL, A.; FREITAS, C. M.; GURGEL, H.; PEDROSO, M. M. Modelos de organização e análise dos indicadores. In: Saúde ambiental: guia básico para construção de indicadores. Ministério da Saúde: BRASIL, 2011.

SORRENTINO, M. Desenvolvimento sustentável e participação: algumas reflexões em voz alta. In: LOUREIRO, C. F. B.; LAYRARGUES, P. P.; CASTRO, R. S. (Orgs.) Educação ambiental: repensando o espaço da cidadania. $5^{a}$ edição. São Paulo: Cortez, 2011.

SOUZA, S. E. O uso de recursos didáticos no ensino escolar. In: I ENCONTRO DE PESQUISA EM EDUCAÇAO, IV JORNADA DE PRÁTICA DE ENSINO, XIII SEMANA DE PEDAGOGIA DA UEM: "INFANCIA E PRATICAS EDUCATIVAS”. Maringá, 2007. Disponível em: http://www.dma.ufv.br/downloads/MAT\%20103/2015II/slides/Rec\%20Didaticos\%20-\%20MAT\%20103\%20-\%202015-II.pdf. Acesso em: 30/09/2017.

VEIGA, J. E. Indicadores de sustentabilidade. Revista Estudos Avançados. São Paulo: 2010 
VIVEIRO, A. A.; DINIZ, R. E. S. Atividades de campo no ensino das ciências e na educação ambiental: refletindo sobre as potencialidades desta estratégia na prática escolar. Revista Ciência em Tela, vol. 2, n.1, 2009. Disponível em: http://www.cienciaemtela.nutes.ufrj.br/artigos/0109viveiro.pdf. Acesso em: 30/09/2017.

VIVEIRO, A. A. Atividade de campo no ensino de ciências: investigando concepções e práticas de um grupo de professores. [dissertação]. Bauru: Universidade Estadual Paulista, 2006.

YAMAMOTO, M.; MA, C. J. Developmente of a Model Instrument of Thermal Power Plant for Undersatanding of Air Pollutant Generation, Asian Journal of Atmospheric Environment, vol. 10, p. 156-161, 2016.

YUCEL, E. O.; OZKAN, M. Developmente and implementation of a instructional design for effective teaching of ecosystem, biodiversity and environmental issues. Educational Sciences: Theory \& Practice, v. 15, p. 1051-1068, 2015.

ZANON, D. A. V; FREITAS, D. A aula de ciências nas séries iniciais do ensino fundamental: ações que favorecem a sua aprendizagem. Ciências \& Cognição; Ano 04, vol. 10, p. 93-103, 2007. 


\section{APÊNDICE}

\subsection{Kit de análise da água}

Componentes:

- 4 tubinhos de garrafa pet;

- 4 tubinhos de caneta;

- 1 caixa pequena de papelão;

- 1 garrafa pet $600 \mathrm{~mL}$;

- 2 m de barbante;

- 1 teste de $\mathrm{pH}$ do fabricante Labcontest;

- 1 teste de amônia tôxica do fabricante Labcontest;

- 1 teste de cloro do fabricante Labcontest;

- 1 folha com as escalas para comparação de pH, amônia, turbidez, cloro e cor;

- 1 termômetro

- 1 manual de instruções;

- 1 folha para preenchimento dos dados obtidos na análise da água.

Custo total: $R \$ 50,00$. O kit de análise da água possibilita a produção de mais 4 kits para os alunos, o que significa um custo de aproximadamente $R \$ \mathbf{1 0 , 0 0 / k i t . ~}$

Figura 15: Kit para análise da água produzido pelos alunos.

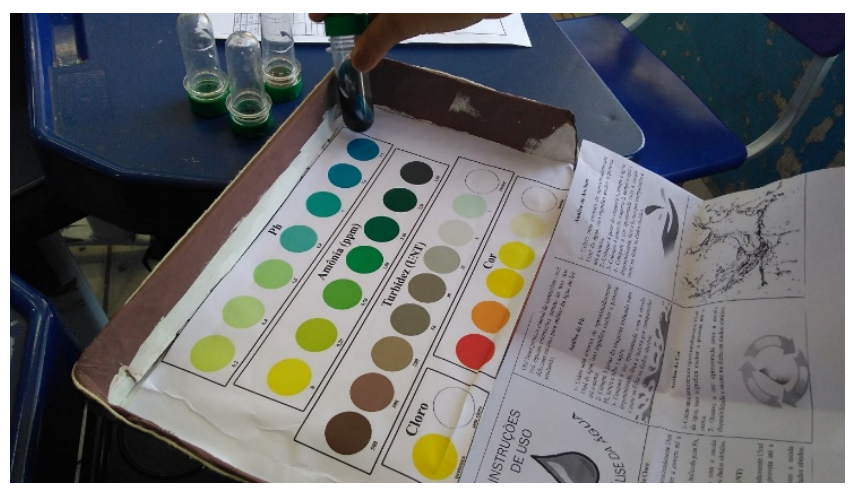

Fonte: Arquivo do autor 
Figura 16: Manual de instruções sobre o uso do kit de análise da água.

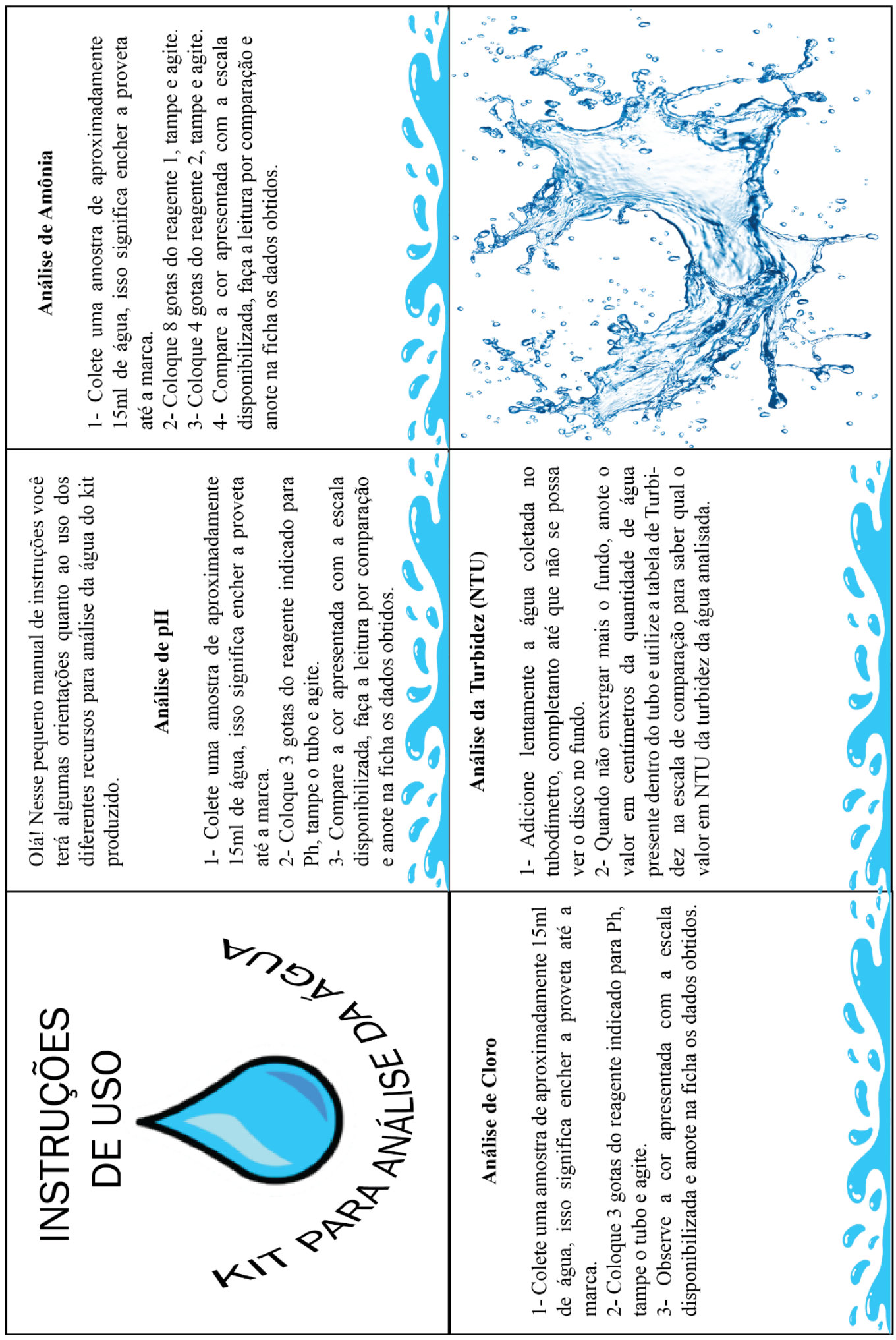

Fonte: Arquivo do autor 
Figura 17: Escala para análise por comparação da água.
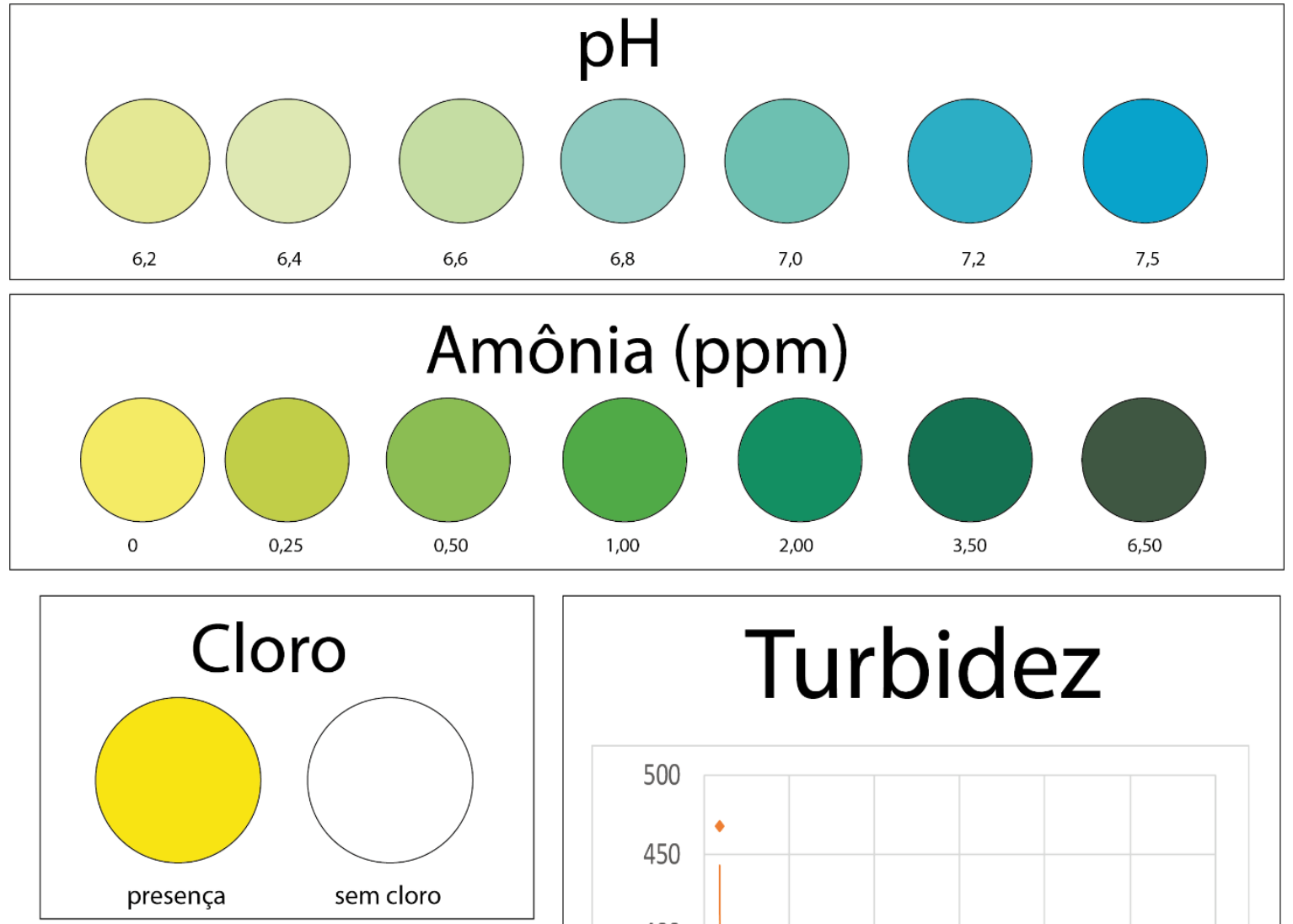

\section{Amônia (teor de $\mathrm{NH}_{3}$ )}
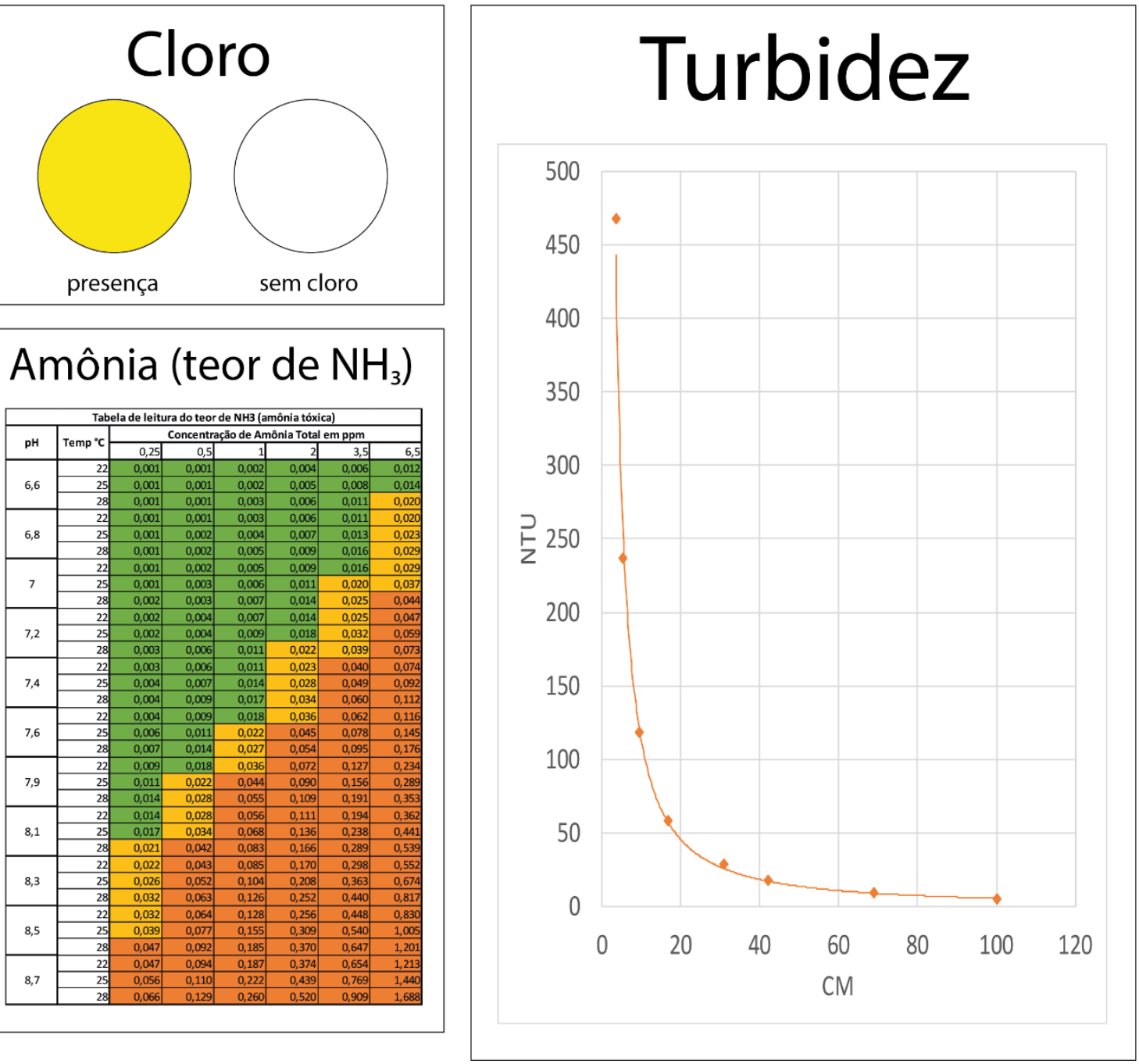

Fonte: Arquivo do autor 
Figura 18: Folha para preenchimento dos alunos com os dados obtidos durante a análise da água.

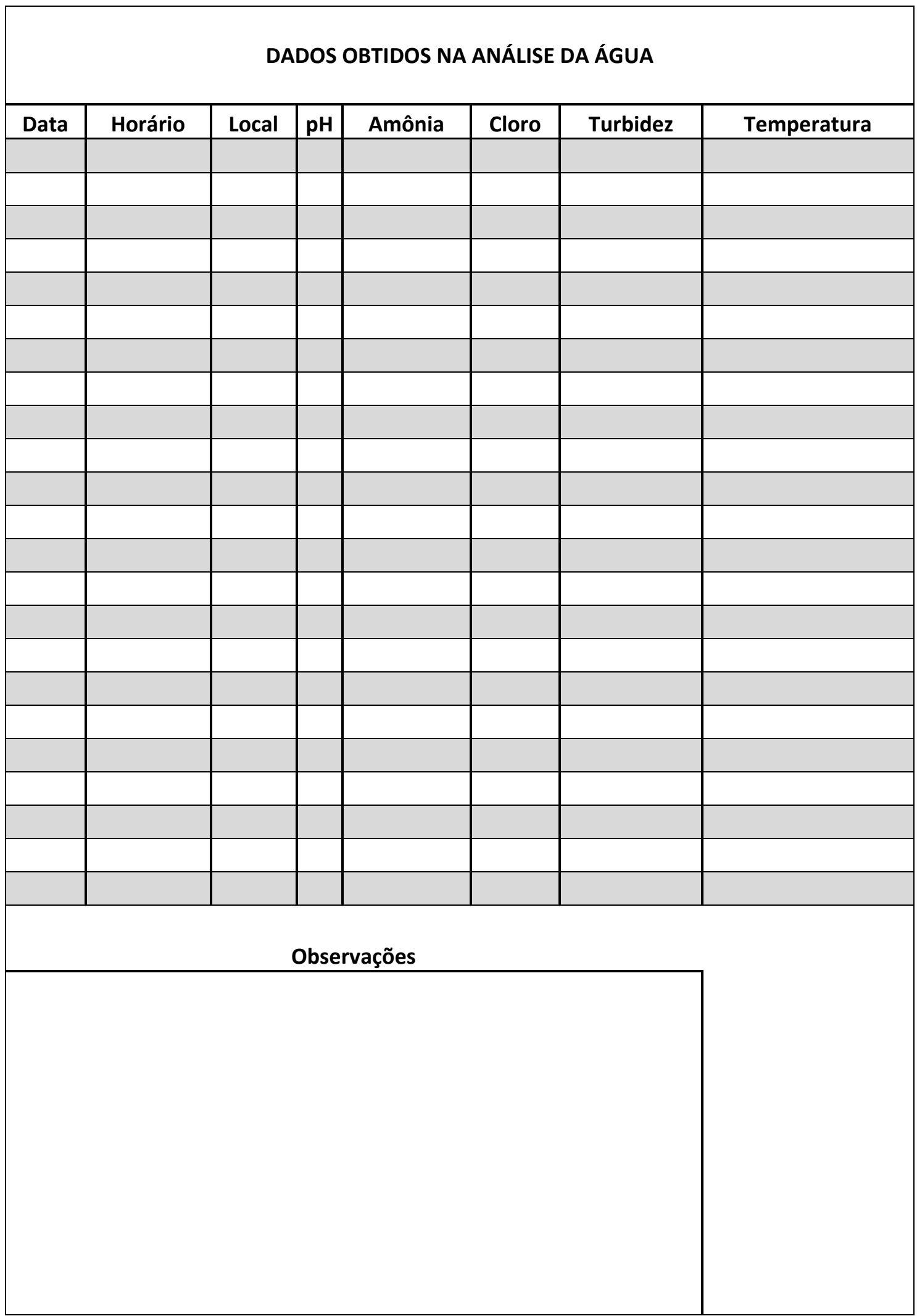




\subsection{Termo de Consentimento Livre e Esclarecido}

\section{TERMO DE CONSENTIMENTO LIVRE E ESCLARECIDO}

Título da Pesquisa: "A construção de matérias didáticos para o ensino das ciências ambientais"

Nome do pesquisador: Wilson Antonio Lopes de Moura- Mestrando em Ciências Ambientais na Escola de Engenharia de São Carlos-EESC/USP

Nome do Orientador: Luiz Antonio Daniel - Professor do Departamento de Hidráulica e Saneamento da EESC-USP

1. A pesquisa: Visa incorporar discussões sobre a construção de materiais didáticos para o ensino das Ciências Ambientais, a partir da compreensão abrangente e integrada de diferentes áreas do conhecimento. Como temas para o estudo são realizadas análises sobre o entorno escolar, o Modelo PEIR (Pressão-Estado-Impacto-Respostas), a produção de um kit de análise da água e a construção de indicadores de desenvolvimento sustentável para a área estudada. Dessa forma, seu objetivo principal é investigar as práticas de formação que possibilitem um ensino mais contextualizado e interdisciplinar, que contribua para reflexões por parte dos professores e alunos com relação ao importante papel do Ensino de Ciências na construção de conhecimentos sobre formas de intervir e interpretar questões socioambientais.

2. Participantes da pesquisa: Alunos do $8^{\circ}$ ano da Escola Municipal de Educação Básica Professor Erotides de Campos, da cidade de Charqueada/SP.

3. Envolvimento na pesquisa: Ao aceitar que seu filho(a) participe deste estudo o (a) Sr. (a) permitirá que os pesquisadores acima citados, possam levantar dados das necessidades formativas dos alunos sobre questões socioambientais. O Sr.(a) e seu Filho (a) tem liberdade de se recusar a participar e ainda se recusar a continuar participando em qualquer fase da pesquisa, sem qualquer prejuízo para o (a) Sr. (a) e seu filho (a). Sempre que quiser poderá pedir mais informações sobre a pesquisa através do e-mail do pesquisador do projeto.

4. Sobre a coleta de dados: Para coleta de dados serão aplicados questionários e entrevistas semiestruturas junto aos alunos, além da realização de atividades de campo nas áreas próximas a escola e aplicação de uma cartilha sobre a análise do entorno escolar. A coleta de dados da pesquisa envolverá também: estudo e levantamento de fontes bibliográficas; distribuição do termo de consentimento; aplicação de questionários presenciais; entrevistas; captura de registros áudio-gravados.

5. Riscos e desconforto: A participação nesta pesquisa não infringe as normas legais e éticas. Nenhum dos procedimentos usados oferece riscos à sua dignidade.

6. Confidencialidade: Todas as informações coletadas neste estudo são estritamente confidenciais. Somente o pesquisador e seu orientador terão conhecimento de sua identidade e se comprometem a mantê-la em sigilo ao publicar os resultados dessa pesquisa.

7. Benefícios: Ao participar desta pesquisa o (a) Sr.(a) e seu filho (a) não terá nenhum benefício direto. Entretanto, esperamos que este estudo possa contribuir para uma reflexão sobre o ensino de questões socioambientais nas escolas, sendo inclusive possível, reafirmar, rever ou redirecionar práticas pedagógicas, no sentido de oferecer ao aluno melhores condições para construir o conhecimento. Os pesquisadores se comprometem a divulgar os resultados obtidos, 
respeitando-se o sigilo das informações coletadas, conforme previsto no item anterior e entregar uma cópia do relatório final aos participantes investigados.

8. Pagamento: O (a) Sr.(a) e seu Filho (a) não terá nenhum tipo de despesa para participar desta pesquisa, bem como nada será pago por sua participação.

Após estes esclarecimentos, solicitamos o seu consentimento de forma livre para participar desta pesquisa. Portanto preencha, por favor, os itens que se seguem: Confiro que recebi cópia deste termo de consentimento, e autorizo a execução do trabalho de pesquisa e a divulgação dos dados obtidos neste estudo.

Obs: Não assine esse termo se ainda tiver dúvida a respeito.

Tendo em vista os itens acima apresentados, eu, de forma livre e esclarecida, manifesto o consentimento para que meu filho (a) possa participar da pesquisa.

Charqueada, de de 2018.

Nome do aluno (a) Participante da Pesquisa

Nome e Assinatura do Responsável pelo(a) aluno(a) participante da Pesquisa

\author{
Pesquisador Wilson Antonio Lopes de Moura \\ Número USP: 9383216
}

Contato do Pesquisador: Wilson Antonio Lopes de Moura - wilson.moura@usp.br Escola de Engenharia de São Carlos- Universidade de São Paulo Av. Trabalhador São Carlense, 400- São Carlos

Telefone (19) 98263-6004 


\subsection{Questionário inicial}

Prezado participante,

O presente instrumento de coleta de dados é um questionário sobre o uso de diferentes recursos didáticos durante as aulas da educação básica. As questões pretendem levantar dados sobre esses recursos e envolve discussões teóricas como também a sua aplicabilidade nas escolas. Ele tem como objetivo contribuir para a pesquisa: "A construção de materiais didáticos para o ensino de ciências ambientais", realizada pelo mestrando Wilson Antonio Lopes de Moura sob a orientação do Prof. Dr. Luiz Antonio Daniel, realizada no Programa de Pós-Graduação em Rede para o Ensino de Ciências Ambientais da Universidade de São Paulo. É importante destacar que a pesquisa garante ao entrevistado o anonimato, portanto os dados obtidos através desse questionário serão utilizados para fins científicos, sem mencionar a origem dos mesmos. Desde já agradecemos a importante contribuição!

\section{Bloco 1: Perfil dos participantes}

1- Nome: Idade:

2- Série/ano em que estuda no Ensino Fundamental II:

( ) $6^{\circ}$ ano ( $) 7^{\circ}$ ano ( $) 8^{\circ}$ ano ( ) $9^{\circ}$ ano

\section{Bloco 2: Questões sobre a educacão ambiental no cotidiano escolar}

3- Ao longo do ano letivo são realizadas atividades de educação ambiental na escola onde você estuda? Se sim, você poderia citar quais os temas abordados nessas atividades?

( ) Não ( ) Sim, os temas são: 
4- No geral quais as disciplinas ou professores costumam se envolver nessas atividades?

5- Você costuma realizar atividades de campo com seus professores? Se sim, em quais áreas:

( ) Não Sim, nas áreas ( )próximas a escola ( )dentro do município ( )fora do município ( )dentro da escola

6- Durante as aulas de educação ambiental o professor costuma utilizar de algum material didático? Se sim, quais:

( ) Não ( )Sim,

quais:

7- Procure explicar o que são as Ciências Ambientais em sua opinião?

8- Como questão final você poderia apontar os problemas ambientais presentes nas áreas próximas a sua escola e relaciona-los com as suas possíveis causas? 


\title{
12.4. Transcrição da Entrevista realizada após a Saída de Campo
}

\author{
Turno Participante Fala
}

$1 \quad P \quad \# 00: 00: 01.4 \#$ Essa é a primeira da nossa atividade de trabalho, as falas agora que vão ser apresentadas, foram feitas após a saída de campo. Os alunos foram conhecer o entorno escolar e anotaram algumas questões relacionadas as dimensões econômica, social, cultural, história e ambiental do entorno escolar. A primeira pergunta que eu faço para que vocês possam falar a vontade, é o que vocês acharam da atividade? Lembrando que você deve falar seu nome e a sua opinião.

\begin{tabular}{lll}
\hline 2 & 3 & $\begin{array}{l}\# 00: 01: 12.4 \# \text { A atividade foi interessante, podemos conhecer melhor o } \\
\text { comércio, os pontos históricos e também os problemas ambientais presentes no } \\
\text { bairro. }\end{array}$ \\
\hline 3 & $\begin{array}{l}\text { \#00:01:25.9\# Gostei da atividade, exploramos o Paraiso e pudemos conhecer } \\
\text { melhor tanto os problemas ambientais como os sociais e aprendemos também } \\
\text { um pouco sobre o passado de alguns locais }\end{array}$ \\
\hline 4 & $\begin{array}{l}\text { \#00:01:48.1\# Eu gostei, porque eu não conhecia o Paraiso e achei bem } \\
\text { interessante o lugar, conhecemos o comércio, eu não sabia que tinha tanto e } \\
\text { vários pontos históricos e culturais. }\end{array}$
\end{tabular}

$5 \quad$ \#00:02:11.6\# Gostei da atividade, porque a gente pode aprofundar os problemas ambientais do bairro e conhecer novos lugares, coisas que nem sabia que tinha no bairro, muitos comércios

$6 \quad$ P $\quad \# 00: 02: 59.8 \#$ Aproveitando a parte do que vocês acharam da atividade, gostaria de fazer uma pergunta específica para os grupos, e cada grupo vai ter uma fala sobre aquilo que fez. Começando pelo grupo da ambiental, quais foram os elementos que mais the chamaram a atenção e você saberiam apontar o que causaria essas situações?

$7 \quad 25 \quad \# 00: 03: 34.4 \#$ A gente viu que há muitos problemas de lixo no Paraiso, mais isso no Faganello, próximo a escola. Acho que o que causa isso é a falta de responsabilidade das pessoas, de saber que é errado fazer isso. Descemos até o rio e tinha uma placa, "proibido jogar lixo e jogar entulho" e lá tinha um monte de lixo. Notamos que nos bueiros tinha bastante lixo e se eles entupirem pode causar enchentes que é uma coisa muito ruim.

\begin{tabular}{lcl}
\hline 8 & $P$ & $\begin{array}{l}\text { \#00:04:25.0\# Para quem estava anotando no mapa, houve alguma dificuldade de } \\
\text { realizar a tarefa? }\end{array}$ \\
\hline 9 & 8 & \#00:04:34.8\# Não tivemos nenhuma dificuldade. \\
\hline 10 & $P$ & $\begin{array}{l}\text { \#00:04:38.3\# O grupo da parte econômica, vocês acharam muitos elementos } \\
\text { econômicos no bairro, quais são eles e qual a sua opinião sobre? }\end{array}$ \\
\hline 11 & 15 & \#00:04:53.5\# Achamos padarias, quitanda, o lugar onde vende ovos, mercados,
\end{tabular}


cabeleireiros, açougue e alguns.

\begin{tabular}{|c|c|c|}
\hline 12 & $\mathrm{P}$ & \#00:05:20.8\# O que vocês acharam desses pontos? \\
\hline 13 & 35 & $\begin{array}{l}\text { \#00:05:28.6\# O bom de ter aqui é que não precisamos ir lá em Charqueada para } \\
\text { procurar uma carne, tudo fica lá praticamente, sai daqui pra ir em Charqueada, } \\
\text { pra ver algumas coisas. Quando o povo começar a conhecer aqui, surge algo de } \\
\text { última hora, tem o comércio aqui, fica mais fácil. }\end{array}$ \\
\hline 14 & $P$ & $\begin{array}{l}\# 00: 05: 52.8 \# \text { O pessoal da parte histórica, o bairro tem muitos elementos } \\
\text { históricos, quais seriam eles e o que você acha da conservação desses lugares? }\end{array}$ \\
\hline 15 & 20 & $\begin{array}{l}\text { \#00:06:29.3\# Não temos muitos pontos históricos, porque está tudo destruído. } \\
\text { Achamos a antiga estação de trem, a Usina São Francisco que antigamente } \\
\text { produzia açúcar, o barracão da usina. }\end{array}$ \\
\hline 16 & $P$ & $\begin{array}{l}\# 00: 06: 58.5 \# \text { O pessoal do grupo cultural, quais foram os pontos principais de } \\
\text { cultura encontrados no bairro? }\end{array}$ \\
\hline 17 & 19 & $\begin{array}{l}\text { \#00:07:18.1\# Achamos vários pontos, mas o que vimos foram igrejas de } \\
\text { diferentes religiões, foram seis no total. }\end{array}$ \\
\hline 18 & $P$ & $\begin{array}{l}\text { \#00:08:09.7\# O grupo social, quais foram os elementos que vocês encontraram? } \\
\text { e qual a opinião de vocês sobre eles? }\end{array}$ \\
\hline 19 & 13 & $\begin{array}{l}\text { \#00:08:19.6\# Descobrimos que temos vários lugares que podemos ir, como a } \\
\text { escola, o campo, a praça, a academia, a própria igreja, o posto e o NAPE, onde } \\
\text { podemos ter acesso fácil. }\end{array}$ \\
\hline
\end{tabular}




\subsection{Transcrição da Entrevista realizada após o fim das aulas realizadas}

Turno Participante

\begin{tabular}{ll}
\hline 13 & \#00:00:04.0\# Professor- Hoje é dia 29 de Novembro, estamos encerrando as \\
& atividades que foram feitas durante essas últimas semanas. São três perguntas \\
& para serem respondidas de forma individual, e as perguntas são: Qual a \\
& importância do Modelo PEIR na sua opinião? Qual a importância dos Indicadores, \\
& que foram trabalhados durante as atividades? E o que achou do projeto em si? \\
& Vamos começar por ordem, lembrando que você deve falar seu nome e discorrer \\
& sobre as questões. \\
\hline 3 & \#00:00:54.2\# A importância do Modelo PEIR, você pode ter uma noção dos \\
& problemas que estão principalmente afetando a cidade ou seu bairro. A \\
& importância dos Indicadores é de que você pode ter um monte de ideias pra \\
& tentar resolver esses problemas. Achei o projeto foi bom \\
\hline 31 & \#00:01:14.3\# Achei que o Modelo PEIR é muito interessante, por causa que ele dá \\
& uma noção para gente saber de como está o nosso bairro, daí junta os indicadores \\
& da para ter uma noção de como está o fluxo, a quantidade, os números de \\
& pessoas que circulam no lugar. E o projeto foi muito legal para nossa sala, que deu \\
& uma nova visão pra gente \\
\hline 33 & \#00:01:50.6\# A importância do Modelo PEIR pra mim, foi que ele mostra, além de \\
& questões ambientais, questões históricas, econômicas e sociais, mostra resumido \\
& que nosso bairro não é só a questão ambiental, onde tem entulho, essas coisas. A \\
& importância dos Indicadores é que mostra o que tem no bairro. O que achei do \\
projeto, foi que aprendi muito, fiquei impressionado quando saímos com você \\
aqui no Paraiso, tinha pouco comércio, mas tinha muito lixo, mas também não era \\
só entulho que nós achamos, no meu caso era a questão ambiental, vimos \\
despejo de esgoto, abando de animais domésticos de carros e materiais de \\
construção.
\end{tabular}

$5 \quad 10$

\#00:03:00.4\# Qual a importância do Modelo PEIR, eu achei importante porque ele é simples e eficaz. Qual a importância dos indicadores, indicam o que está acontecendo e qual a melhor resposta. O que achei do projeto, achei que ele é interessante.
62
2
\#00:03:16.9\# Eu acho o Modelo PEIR bom porque ele é mais fácil de organizar. Os indicadores são melhores para saber se aquilo está bom ou ruim. E o projeto eu achei interessante, muito fácil e muito bom de fazer com os alunos.
$7 \quad 7 \quad$ \#00:03:38.3\# A importância que eu acho do Modelo PEIR é que ele ajuda você a pensar um pouco mais sobre o que está acontecendo no bairro. A importância dos Indicadores é que eles facilitam as coisas para você. O que eu acho do projeto é que ele é legal e você vai conhecendo várias coisas que você não sabia sobre o bairro.


podemos analisar o entorno escolar e aprender mais coisas sobre o bairro. A importância dos Indicadores é que podemos descobrir mais as coisas que temos no bairro e o que estiver ruim a gente pode melhorar.

\begin{tabular}{|c|c|c|}
\hline 9 & 26 & $\begin{array}{l}\text { \#00:04:38.7\# Eu gostei bastante do Modelo PEIR porque é uma análise ambiental, } \\
\text { que nos permite achar os problemas e os classifica-los. Gostei bastante dos } \\
\text { Indicadores pois ele nos ajuda a resolver esses problemas junto do Modelo PEIR. } \\
\text { O projeto eu gostei bastante pois ajudamos também as empresas, conseguimos } \\
\text { alguns clientes para ela e eles também nos ajudaram. }\end{array}$ \\
\hline 10 & 8 & $\begin{array}{l}\text { \#00:05:04.1\# Sobre o Modelo PEIR eu gostei muito, achei muito importante saber } \\
\text { dos problemas do local onde nós fomos. Sobre os Indicadores, achei muito } \\
\text { importante saber como resolver os problemas. Sobre o projeto, achei muito } \\
\text { interessante, pois além de ajudar as pessoas, aprendemos muito. }\end{array}$ \\
\hline 11 & 17 & $\begin{array}{l}\text { \#00:05:27.5\# A importância do Modelo PEIR é que a gente pode identificar os } \\
\text { problemas que tem no bairro e região. A importância dos Indicadores é que ele dá } \\
\text { possíveis soluções para os problemas. Eu achei o projeto bom, pois dá para } \\
\text { conhecer melhor o bairro. }\end{array}$ \\
\hline
\end{tabular}

\subsection{Modelo PEIR produzido pelos alunos}

\begin{tabular}{|c|c|c|c|c|}
\hline \multicolumn{2}{|c|}{ Respostas dos alunos sobre o Modelo PEIR } \\
\hline Numero & Pressão & Estado & Impacto & Respostas \\
\hline 2 & Desmatamento & Falta de árvores & $\begin{array}{c}\text { Falta de Frutos e } \\
\text { Folhas }\end{array}$ & Educação e multas \\
\hline 3 & $\begin{array}{c}\text { Poucos espaços, } \\
\text { pois o bairro é } \\
\text { pequeno }\end{array}$ & $\begin{array}{c}\text { Pouco espaço público } \\
\text { do bairro }\end{array}$ & $\begin{array}{c}\text { Pessoas } \\
\text { insatisfeitas por } \\
\text { falta de recurso }\end{array}$ & $\begin{array}{c}\text { As pessoas frequentam } \\
\text { espaços públicos de } \\
\text { outras cidades }\end{array}$ \\
\hline 4 & $\begin{array}{c}\text { Entulhos de lixo e } \\
\text { despejo de esgoto } \\
\text { nos rios }\end{array}$ & $\begin{array}{c}\text { Lixos jogados nas ruas, } \\
\text { rios sujos e com mau } \\
\text { cheiro }\end{array}$ & $\begin{array}{c}\text { Animais morrendo, } \\
\text { pessoas doentes e } \\
\text { atração de animais } \\
\text { para o esgoto }\end{array}$ & $\begin{array}{c}\text { Um lugar para despejar o } \\
\text { lixo e os esgotos }\end{array}$ \\
\hline
\end{tabular}




\begin{tabular}{|c|c|c|c|c|}
\hline 5 & $\begin{array}{l}\text { Número de áreas } \\
\text { com entulho }\end{array}$ & $\begin{array}{c}\text { O nível de sujeira nas } \\
\text { ruas }\end{array}$ & $\begin{array}{c}\text { Número de bueiros } \\
\text { entupidos }\end{array}$ & $\begin{array}{l}\text { Ver quantas pessoas } \\
\text { estão colaborando }\end{array}$ \\
\hline 6 & $\begin{array}{l}\text { Peso das máquinas } \\
\text { Ruas asfaltadas }\end{array}$ & $\begin{array}{l}\text { Ruas esburacadas } \\
\text { Asfalto mau ajeitado } \\
\text { Ruas mau cuidadas }\end{array}$ & $\begin{array}{c}\text { Crianças podem se } \\
\text { machucar } \\
\text { Pessoas podem } \\
\text { sofrer acidentes } \\
\text { Carros podem } \\
\text { bater }\end{array}$ & $\begin{array}{l}\text { As ruas podem ser um } \\
\text { perigo para as pessoas }\end{array}$ \\
\hline 7 & Falta de cuidado & $\begin{array}{l}\text { Caixa de água sem } \\
\text { condições de usar }\end{array}$ & $\begin{array}{l}\text { Sujeira, falta de } \\
\text { limpeza }\end{array}$ & $\begin{array}{c}\text { Ter mais cuidados, mais } \\
\text { limpezas }\end{array}$ \\
\hline 9 & Esgoto & O rio poluído & $\begin{array}{c}\text { Pode causar } \\
\text { infecções, morte de } \\
\text { peixes }\end{array}$ & $\begin{array}{l}\text { Melhoria na captação de } \\
\text { esgoto, uma limpeza no } \\
\text { rio }\end{array}$ \\
\hline 10 & $\begin{array}{l}\text { Carros } \\
\text { Indústrias }\end{array}$ & Poluição do ar & $\begin{array}{l}\text { Aumento do } \\
\text { aquecimento global } \\
\text { Número de pessoas } \\
\text { doentes por ano }\end{array}$ & $\begin{array}{c}\text { Carros menos poluentes } \\
\text { Dar multas para usinas } \\
\text { que soltam fumaças }\end{array}$ \\
\hline 12 & $\begin{array}{l}\text { A má conservação } \\
\text { dos locais } \\
\text { históricos }\end{array}$ & $\begin{array}{l}\text { O estado está péssimo, } \\
\text { pois está sem utilidade, } \\
\text { sem funcionamento e } \\
\text { não está conservado }\end{array}$ & $\begin{array}{l}\text { Falta de empregos } \\
\text { e não há lugares } \\
\text { históricos no bairro }\end{array}$ & $\begin{array}{l}\text { Reformar esses lugares e } \\
\text { contratar pessoas para } \\
\text { trabalhar e ajudar a } \\
\text { conservar esses pontos }\end{array}$ \\
\hline 14 & $\begin{array}{c}\text { O bairro é } \\
\text { pequeno, pouco } \\
\text { comércio no bairro }\end{array}$ & $\begin{array}{l}\text { Não há muitos espaços } \\
\text { públicos no bairro } \\
\text { Estes espaços públicos } \\
\text { estão com poucos } \\
\text { cuidados necessários }\end{array}$ & $\begin{array}{c}\text { As pessoas não } \\
\text { podem aproveitar } \\
\text { os espaços públicos }\end{array}$ & $\begin{array}{c}\text { Aumentar os cuidados } \\
\text { no bairro } \\
\text { Aumentar lugares no } \\
\text { bairro }\end{array}$ \\
\hline 15 & $\begin{array}{l}\text { As pessoas } \\
\text { precisam de } \\
\text { educação }\end{array}$ & $\begin{array}{l}\text { Entulho onde as pessoas } \\
\text { acumulam nas ruas e } \\
\text { nas matas, e despejos } \\
\text { de esgotos nos rios }\end{array}$ & $\begin{array}{l}\text { Entulhos entopem } \\
\text { bueiros, mau } \\
\text { cheiro e atraem } \\
\text { bichos }\end{array}$ & $\begin{array}{l}\text { Educação melhor e } \\
\text { multas }\end{array}$ \\
\hline
\end{tabular}




\begin{tabular}{|c|c|c|c|c|}
\hline 16 & $\begin{array}{c}\text { Pessoas jogam lixos } \\
\text { nas ruas }\end{array}$ & Lixo na rua & $\begin{array}{l}\text { Entope o bueiro } \\
\text { quando chove }\end{array}$ & $\begin{array}{l}\text { Multa para quem jogar } \\
\text { lixo }\end{array}$ \\
\hline 17 & $\begin{array}{l}\text { Pessoas jogam lixo } \\
\text { e entulho na rua }\end{array}$ & $\begin{array}{c}\text { As ruas ficam cada vez } \\
\text { mais sujas }\end{array}$ & $\begin{array}{l}\text { A poluição do ar e } \\
\text { os bueiros } \\
\text { entopem com as } \\
\text { chuvas }\end{array}$ & $\begin{array}{l}\text { Parar de jogar entulho } \\
\text { nas ruas e criar um } \\
\text { ponto específico para a } \\
\text { população jogar lixo }\end{array}$ \\
\hline 18 & $\begin{array}{l}\text { A má conservação } \\
\text { dos pontos } \\
\text { turísticos do bairro }\end{array}$ & $\begin{array}{l}\text { Não tem funcionamento } \\
\text { e mau estado dos } \\
\text { pontos históricos }\end{array}$ & $\begin{array}{l}\text { Falta de emprego, } \\
\text { falta de pontos } \\
\text { turísticos no bairro }\end{array}$ & $\begin{array}{c}\text { Reformar esses lugares e } \\
\text { contratar pessoas para } \\
\text { conservar esses pontos e } \\
\text { trabalhar }\end{array}$ \\
\hline 19 & $\begin{array}{l}\text { Animais } \\
\text { abandonados nas } \\
\text { ruas }\end{array}$ & $\begin{array}{c}\text { Muitos cães e gatos na } \\
\text { rua passando fome e } \\
\text { morrendo por causa } \\
\text { disso }\end{array}$ & $\begin{array}{l}\text { Morte de animais e } \\
\text { muito lixo revirado } \\
\text { nas ruas por esses } \\
\text { animais } \\
\text { procurarem comida }\end{array}$ & $\begin{array}{l}\text { Castrar os animais para } \\
\text { que diminua esse } \\
\text { número e a doação } \\
\text { desses animais }\end{array}$ \\
\hline 21 & $\begin{array}{c}\text { Falta de } \\
\text { consciência das } \\
\text { pessoas }\end{array}$ & $\begin{array}{l}\text { Abandono de materiais } \\
\text { de construções }\end{array}$ & $\begin{array}{c}\text { Doenças, atrai } \\
\text { bichos perigosos } \\
\text { para as casas e } \\
\text { alagamentos de } \\
\text { esgotos }\end{array}$ & $\begin{array}{c}\text { Jogas esses lixos aos } \\
\text { devidos lugares }\end{array}$ \\
\hline 22 & $\begin{array}{c}\text { Lixo no mato } \\
\text { Bastante lixeiras no } \\
\text { bairro }\end{array}$ & Entulho no mato & $\begin{array}{c}\text { Poluição } \\
\text { pode destruir as } \\
\text { áreas naturais e os } \\
\text { animais }\end{array}$ & $\begin{array}{c}\text { Multa pra quem joga lixo } \\
\text { no mato }\end{array}$ \\
\hline 23 & $\begin{array}{c}\text { Bichos } \\
\text { peçonhentos } \\
\text { podem invadir } \\
\text { casas, como } \\
\text { escorpiões, cobra, } \\
\text { aranhas etc. }\end{array}$ & Entulhos pelo bairro & $\begin{array}{l}\text { Não tem um } \\
\text { descarte correto } \\
\text { por falta das } \\
\text { pessoas e da } \\
\text { prefeitura }\end{array}$ & $\begin{array}{l}\text { Construir locais corretos } \\
\text { para o descarte do } \\
\text { entulho e mais } \\
\text { responsabilidade da } \\
\text { população }\end{array}$ \\
\hline 25 & Lixo nas matas & Ambiente poluído & $\begin{array}{l}\text { Pode causar } \\
\text { algumas doenças } \\
\text { na população }\end{array}$ & $\begin{array}{c}\text { Ter mais lugares onde } \\
\text { jogar o lixo, com lixeiras } \\
\text { espalhadas }\end{array}$ \\
\hline
\end{tabular}




\begin{tabular}{|c|c|c|c|c|}
\hline 28 & $\begin{array}{l}\text { Falta de lugares } \\
\text { para jogar entulho } \\
\text { e a falta de } \\
\text { consciência das } \\
\text { pessoas }\end{array}$ & Entulho jogado nas ruas & $\begin{array}{l}\text { Isso atrais bichos } \\
\text { perigosos e } \\
\text { doenças }\end{array}$ & $\begin{array}{c}\text { Ter mais lugares nos } \\
\text { bairros para jogar } \\
\text { entulho }\end{array}$ \\
\hline 30 & $\begin{array}{l}\text { Frequência de ida } \\
\text { de pessoas em } \\
\text { espaços públicos } \\
\text { (mensalmente) }\end{array}$ & $\begin{array}{c}\text { Aumento/ diminuição } \\
\text { do número de espaços } \\
\text { públicos no bairro por } \\
\text { anos }\end{array}$ & $\begin{array}{l}\text { Fazer a verificação } \\
\text { se as pessoas } \\
\text { continuam ou não } \\
\text { indo aos espaços } \\
\text { públicos }\end{array}$ & $\begin{array}{l}\text { Entrevistar a prefeitura } \\
\text { para ver o número de } \\
\text { pessoas que tiveram } \\
\text { alguma iniciativa (tanto } \\
\text { para a conservação, } \\
\text { quanto a criação de } \\
\text { novos locais) }\end{array}$ \\
\hline 33 & $\begin{array}{l}\text { Lixo nos bueiros } \\
\text { Abandono de } \\
\text { animais domésticos }\end{array}$ & $\begin{array}{l}\text { Entupimento onde com } \\
\text { chuva vai fazer uma } \\
\text { poça de água, onde } \\
\text { pode inundar a ponte e } \\
\text { ter reprodução de } \\
\text { insertos e animais, } \\
\text { causando doenças nas } \\
\text { pessoas } \\
\text { Animais abandonados }\end{array}$ & $\begin{array}{l}\text { Doenças, } \\
\text { reproduções e } \\
\text { inundações } \\
\text { Eles podem pegar } \\
\text { doença e passar } \\
\text { para as pessoas }\end{array}$ & $\begin{array}{l}\text { Mais lixeiras e menos } \\
\text { poluição } \\
\text { Mais abrigos de animais } \\
\text { e veterinários }\end{array}$ \\
\hline 35 & $\begin{array}{c}\text { Poucas pessoas } \\
\text { valorizam a cultura }\end{array}$ & $\begin{array}{c}\text { Poucos espaços } \\
\text { culturais }\end{array}$ & $\begin{array}{c}\text { Pouco } \\
\text { conhecimento para } \\
\text { a população }\end{array}$ & $\begin{array}{l}\text { Prefeitura começar a } \\
\text { focar em construir } \\
\text { espaços culturais }\end{array}$ \\
\hline 36 & Bairro pequeno & $\begin{array}{l}\text { Poucos pontos turísticos } \\
\text { no bairro }\end{array}$ & $\begin{array}{l}\text { Não tem lugar para } \\
\text { se distrair }\end{array}$ & $\begin{array}{l}\text { Divulgação dos pontos } \\
\text { turísticos }\end{array}$ \\
\hline 37 & $\begin{array}{l}\text { Necessidade da } \\
\text { madeira para } \\
\text { produção de } \\
\text { móveis, papel e } \\
\text { materiais para } \\
\text { construção } \\
\end{array}$ & $\begin{array}{c}\text { Pouca vegetação, } \\
\text { desmatamento, } \\
\text { deslizamento e falta de } \\
\text { chuva }\end{array}$ & $\begin{array}{l}\text { Desmatamento } \\
\text { gerando um } \\
\text { aumento da } \\
\text { temperatura e } \\
\text { morte de animais }\end{array}$ & $\begin{array}{l}\text { Reflorestamento, multas } \\
\text { para quem cortar as } \\
\text { árvores, praticar o } \\
\text { desenvolvimento } \\
\text { sustentável e investir em } \\
\text { educação } \\
\end{array}$ \\
\hline 38 & $\begin{array}{l}\text { Não tem local } \\
\text { adequado para } \\
\text { jogar os lixos }\end{array}$ & $\begin{array}{l}\text { Mau cheiro do lixo em } \\
\text { locais não adequados }\end{array}$ & $\begin{array}{l}\text { Problemas de } \\
\text { saúde e aumento } \\
\text { dos animais que } \\
\text { trazem doenças }\end{array}$ & $\begin{array}{c}\text { Limpeza das áreas, } \\
\text { multas, locais para jogar } \\
\text { o lixo, campanhas para } \\
\text { ajudar as pessoas a } \\
\text { refletir }\end{array}$ \\
\hline
\end{tabular}




\begin{tabular}{|c|c|c|c|c|}
\hline & $\begin{array}{c}\text { Número de saídas } \\
\text { de esgoto, falta de } \\
\text { tratamento }\end{array}$ & $\begin{array}{c}\text { Rio poluído, apresenta } \\
\text { mau cheiro, cor da água } \\
\text { e peixe morto }\end{array}$ & $\begin{array}{c}\text { Doenças na } \\
\text { população, número } \\
\text { de pessoas nos } \\
\text { hospitais e falta na } \\
\text { escola por doença }\end{array}$ & $\begin{array}{c}\text { Melhoria no saneamento } \\
\text { básico, diminuição do } \\
\text { esgoto e tratamento }\end{array}$ \\
\hline
\end{tabular}

\subsection{Indicadores de Desenvolvimento Sustentável produzido pelos alunos}

\begin{tabular}{|c|c|c|c|c|}
\hline \multicolumn{5}{|c|}{ Respostas dos alunos sobre os Indicadores possíveis para o Modelo PEIR apresentado } \\
\hline Numero & Pressão & Estado & Impacto & Respostas \\
\hline 2 & $\begin{array}{l}\text { Árvores que nos dão } \\
\text { frutos } \\
\text { As pessoas nem ligam }\end{array}$ & $\begin{array}{l}\text { Sem sombra o ano } \\
\text { inteiro } \\
\text { Falta de } \\
\text { conscientização }\end{array}$ & $\begin{array}{l}\text { Sumiço de animais e } \\
\text { aves } \\
\text { Sem cultura no local }\end{array}$ & $\begin{array}{c}\text { Número de árvores } \\
\text { cortadas e plantadas e } \\
\text { multas levadas } \\
\text { Número de visitantes } \\
\text { anual ou mensal }\end{array}$ \\
\hline 3 & $\begin{array}{c}\text { Poderia ter mais } \\
\text { espaços para o bairro } \\
\text { crescer mais }\end{array}$ & $\begin{array}{l}\text { Poderia crescer mais } \\
\text { ter mais comércio } \\
\text { para que as pessoas } \\
\text { pudessem vender } \\
\text { mais }\end{array}$ & $\begin{array}{l}\text { Que poderia ter mais } \\
\text { recurso no bairro }\end{array}$ & $\begin{array}{l}\text { Que no bairro poderia } \\
\text { ter mais comércio para } \\
\text { as pessoas não sair do } \\
\text { bairro para ir comprar } \\
\text { em outro lugar }\end{array}$ \\
\hline 4 & $\begin{array}{l}\text { Lixos jogados nas } \\
\text { ruas e rios sujos e } \\
\text { fedendo }\end{array}$ & $\begin{array}{l}\text { Por causa das coisas } \\
\text { jogadas nas ruas, o rio } \\
\text { cheirando mau e } \\
\text { peixes mortos }\end{array}$ & $\begin{array}{l}\text { Muitos peixes } \\
\text { morrendo e muitas } \\
\text { pessoas doentes }\end{array}$ & $\begin{array}{c}\text { Jogar lixo nas lixeiras e } \\
\text { parar de jogar esgoto } \\
\text { no rio }\end{array}$ \\
\hline 5 & $\begin{array}{c}\text { Pessoas jogam lixo e } \\
\text { entulho nas ruas }\end{array}$ & $\begin{array}{c}\text { As ruas ficam cada vez } \\
\text { mais sujas }\end{array}$ & Bueiros entupidos & $\begin{array}{l}\text { Parar de jogar entulho } \\
\text { nas ruas e criar um } \\
\text { ponto (local) específico } \\
\text { para que o lixo seja } \\
\text { depositado somente ali }\end{array}$ \\
\hline 6 & $\begin{array}{c}\text { Número de } \\
\text { maquinares por ano }\end{array}$ & $\begin{array}{l}\text { Número de ruas } \\
\text { esburacadas por ano }\end{array}$ & $\begin{array}{l}\text { Pessoas e crianças } \\
\text { podem sofrer } \\
\text { acidentes }\end{array}$ & $\begin{array}{l}\text { Conscientização da } \\
\text { prefeitura sobre a } \\
\text { questão das ruas e o } \\
\text { que ela pode fazer com } \\
\text { tudo isso }\end{array}$ \\
\hline
\end{tabular}




\begin{tabular}{|c|c|c|c|c|}
\hline 7 & $\begin{array}{l}\text { Sem lucro nos } \\
\text { comércios }\end{array}$ & $\begin{array}{l}\text { Poucos comércios sem } \\
\text { lucro }\end{array}$ & $\begin{array}{c}\text { Pode começar a } \\
\text { faltar coisas para as } \\
\text { pessoas }\end{array}$ & $\begin{array}{l}\text { Poderia abrir novos } \\
\text { comércios e entrar } \\
\text { mais dinheiro neles }\end{array}$ \\
\hline 9 & $\begin{array}{l}\text { O cano do esgoto cai } \\
\text { no rio, número dos } \\
\text { canos de esgoto }\end{array}$ & $\begin{array}{c}\text { A aparência e o cheiro } \\
\text { do rio }\end{array}$ & $\begin{array}{l}\text { Número de pessoas } \\
\text { que pegam } \\
\text { contaminação ao } \\
\text { entrar em contato } \\
\text { com a água por mês }\end{array}$ & $\begin{array}{l}\text { Número de pessoas } \\
\text { que ajudam a } \\
\text { preservação do meio } \\
\text { ambiente por ano }\end{array}$ \\
\hline 10 & $\begin{array}{c}\text { Números de carros e } \\
\text { de indústrias }\end{array}$ & O ar poluído & $\begin{array}{l}\text { Temperatura média } \\
\text { do dia } \\
\text { Número de pessoas } \\
\text { que vão para o } \\
\text { hospital }\end{array}$ & $\begin{array}{c}\text { Número de multas } \\
\text { dadas }\end{array}$ \\
\hline 12 & $\begin{array}{l}\text { Através de pesquisas } \\
\text { e ninguém se importa } \\
\text { com esses pontos } \\
\text { Número de pesquisas } \\
\text { feitas em lugares } \\
\text { históricos }\end{array}$ & $\begin{array}{l}\text { Ninguém cuida desses } \\
\text { lugares e ninguém } \\
\text { frequenta esses locais } \\
\text { Lugares sem } \\
\text { funcionamento com } \\
\text { má conservação }\end{array}$ & $\begin{array}{c}\text { Não há muitas } \\
\text { pessoas com } \\
\text { capacidade de } \\
\text { trabalhar nesses } \\
\text { locais } \\
\text { Número de pessoas } \\
\text { desempregadas } \\
\text { devido a falta de } \\
\text { lugares }\end{array}$ & $\begin{array}{l}\text { Número de lugares } \\
\text { reformados }\end{array}$ \\
\hline 14 & $\begin{array}{c}\text { Número de comércio } \\
\text { e de cuidados do } \\
\text { bairro }\end{array}$ & $\begin{array}{l}\text { Número de espaços } \\
\text { públicos }\end{array}$ & $\begin{array}{l}\text { O mau } \\
\text { aproveitamento da } \\
\text { população }\end{array}$ & $\begin{array}{c}\text { Ajudar o bairro a ter } \\
\text { mais cuidados }\end{array}$ \\
\hline 15 & $\begin{array}{l}\text { Poderiam refletir e } \\
\text { terem respeito ao } \\
\text { fazerem coisa errada }\end{array}$ & $\begin{array}{l}\text { Ter um lugar próprio } \\
\text { para descartar os lixos } \\
\text { e tratamento para } \\
\text { esgotos }\end{array}$ & $\begin{array}{l}\text { Parar de jogar } \\
\text { entulhos nas ruas e } \\
\text { rios, manter os } \\
\text { locais limpos }\end{array}$ & $\begin{array}{l}\text { Placas dando aviso, } \\
\text { multas e passeatas } \\
\text { falando sobre o caso }\end{array}$ \\
\hline 16 & $\begin{array}{l}\text { Rio sujo, peixes } \\
\text { mortos }\end{array}$ & Lixo na rua & Enchentes no bairro & $\begin{array}{c}\text { Multa para pessoas que } \\
\text { jogam lixo }\end{array}$ \\
\hline
\end{tabular}




\begin{tabular}{|c|c|c|c|c|}
\hline 17 & $\begin{array}{l}\text { Número de áreas } \\
\text { com entulho }\end{array}$ & $\begin{array}{l}\text { O nível de sujeira nas } \\
\text { ruas }\end{array}$ & Bueiros entupidos & $\begin{array}{l}\text { Ver o quanto as } \\
\text { pessoas estão } \\
\text { colaborando }\end{array}$ \\
\hline 18 & $\begin{array}{c}\text { Bairro pequeno e } \\
\text { poucas pessoas se } \\
\text { preocupam em } \\
\text { cuidar desses locais. } \\
\text { Também sabemos } \\
\text { disso por meio de } \\
\text { pesquisas desses } \\
\text { lugares históricos }\end{array}$ & $\begin{array}{l}\text { Ninguém cuida desses } \\
\text { lugares e não há } \\
\text { pessoas que } \\
\text { frequentam esses } \\
\text { locais, lugares sem } \\
\text { funcionamento e em } \\
\text { má conservação }\end{array}$ & $\begin{array}{c}\text { Não há muitas } \\
\text { pessoas jovens que } \\
\text { tenham capacidade } \\
\text { para cuidar desses } \\
\text { locais } \\
\text { Número de } \\
\text { desempregados por } \\
\text { falta de locais } \\
\end{array}$ & $\begin{array}{c}\text { Voltar ao } \\
\text { funcionamento desses } \\
\text { estabelecimentos } \\
\text { Número de locais } \\
\text { reformados }\end{array}$ \\
\hline 19 & $\begin{array}{c}\text { Número de animais } \\
\text { abandonados por } \\
\text { mês }\end{array}$ & $\begin{array}{l}\text { Número de animais } \\
\text { nas ruas passando } \\
\text { fome, magros e } \\
\text { doentes }\end{array}$ & $\begin{array}{c}\text { Número de animais } \\
\text { doentes }\end{array}$ & $\begin{array}{c}\text { Número de animais } \\
\text { castrados e doados por } \\
\text { mês }\end{array}$ \\
\hline 21 & $\begin{array}{l}\text { Por que tem pouco, } \\
\text { tem muitas pessoas e } \\
\text { não tem espaços } \\
\text { públicos para elas }\end{array}$ & Pouco espaço público & $\begin{array}{c}\text { Sem lugar para } \\
\text { sentar se divertir e } \\
\text { conversar }\end{array}$ & $\begin{array}{c}\text { Abrir mais espaços para } \\
\text { as pessoas se } \\
\text { divertirem }\end{array}$ \\
\hline 22 & $\begin{array}{l}\text { Ter mais lugares no } \\
\text { bairro para jogar } \\
\text { entulho }\end{array}$ & Entulho nos matos & $\begin{array}{c}\text { Poluição da natureza } \\
\text { e desmatamento }\end{array}$ & $\begin{array}{l}\text { Conscientização das } \\
\text { pessoas sobre a } \\
\text { questão do entulho }\end{array}$ \\
\hline 23 & $\begin{array}{l}\text { Pessoas doentes } \\
\text { Número de pessoas } \\
\text { doentes }\end{array}$ & Falta de medicamento & $\begin{array}{l}\text { Pouca quantidade de } \\
\text { medicamento no } \\
\text { posto/hospital } \\
\text { Número de } \\
\text { medicamento }\end{array}$ & $\begin{array}{l}\text { O aumento de } \\
\text { medicamento em } \\
\text { posto/hospital }\end{array}$ \\
\hline 25 & Lixo na mata & Ambiente sujo & $\begin{array}{l}\text { Mau cheiro no } \\
\text { ambiente }\end{array}$ & $\begin{array}{l}\text { População ter um } \\
\text { pouco mais de } \\
\text { informação sobre a } \\
\text { causa e ter mais lixeiras }\end{array}$ \\
\hline
\end{tabular}




\begin{tabular}{|c|c|c|c|c|}
\hline 28 & $\begin{array}{c}\text { Ter mais lugares no } \\
\text { bairro para jogar } \\
\text { entulho }\end{array}$ & $\begin{array}{l}\text { Aparência e animais } \\
\text { indesejados }\end{array}$ & $\begin{array}{c}\text { Aumenta o número } \\
\text { de mortes e doenças } \\
\text { nos hospitais }\end{array}$ & $\begin{array}{l}\text { Dar multa para pessoas } \\
\text { que jogam entulho nos } \\
\text { lugares errados }\end{array}$ \\
\hline 30 & $\begin{array}{c}\text { O bairro ser } \\
\text { pequeno, a carência } \\
\text { de circulação de } \\
\text { pessoas nesses } \\
\text { espaços }\end{array}$ & $\begin{array}{l}\text { Poucos espaços } \\
\text { públicos }\end{array}$ & $\begin{array}{l}\text { Desânimo das } \\
\text { pessoas para ir a } \\
\text { esses lugares }\end{array}$ & $\begin{array}{l}\text { Fazer a prefeitura ter } \\
\text { uma iniciativa de } \\
\text { construir mais espaços } \\
\text { públicos ou ajudar a } \\
\text { conservar o que temos }\end{array}$ \\
\hline 33 & $\begin{array}{l}\text { Por ter água ainda } \\
\text { parada depois de } \\
\text { tanto tempo } \\
\text { Número alto de } \\
\text { animais na rua }\end{array}$ & $\begin{array}{l}\text { Água parada demais, } \\
\text { cheira mau } \\
\text { Muitos animais na rua }\end{array}$ & $\begin{array}{l}\text { Mau cheiro, doenças } \\
\text { e reprodução de } \\
\text { insetos } \\
\text { Mau cheiro de } \\
\text { cachorro, mais risco } \\
\text { de doenças, mais } \\
\text { riscos de ser atacado } \\
\text { por causa de comida }\end{array}$ & $\begin{array}{l}\text { Responsabilidade, } \\
\text { educação, mais } \\
\text { projetos escolares } \\
\text { responsabilidade e } \\
\text { mais abrigos para } \\
\text { acolher os animais }\end{array}$ \\
\hline 35 & $\begin{array}{l}\text { Poucas pessoas } \\
\text { valorizam a cultura } \\
\text { Número de pessoas } \\
\text { que valorizam e se } \\
\text { importam com o } \\
\text { estado da cultura }\end{array}$ & $\begin{array}{l}\text { Poucos espaços } \\
\text { culturais } \\
\text { Número de espaços } \\
\text { culturais }\end{array}$ & $\begin{array}{l}\text { Pouco conhecimento } \\
\text { da população } \\
\text { Número de pessoas } \\
\text { que conhecem a } \\
\text { cultura local }\end{array}$ & $\begin{array}{l}\text { Prefeitura começa a } \\
\text { focar a construir } \\
\text { espaços culturais } \\
\text { Número de } \\
\text { construções em } \\
\text { andamento }\end{array}$ \\
\hline 36 & $\begin{array}{c}\text { Pouca divulgação dos } \\
\text { pontos turísticos }\end{array}$ & $\begin{array}{l}\text { Poucos pontos } \\
\text { turísticos no bairro }\end{array}$ & $\begin{array}{l}\text { Número de pontos } \\
\text { turísticos no bairro }\end{array}$ & $\begin{array}{c}\text { Aumentar os pontos } \\
\text { turísticos no bairro }\end{array}$ \\
\hline
\end{tabular}


12.8. Produto: Analisando o entorno escolar: um guia para construção de Indicadores

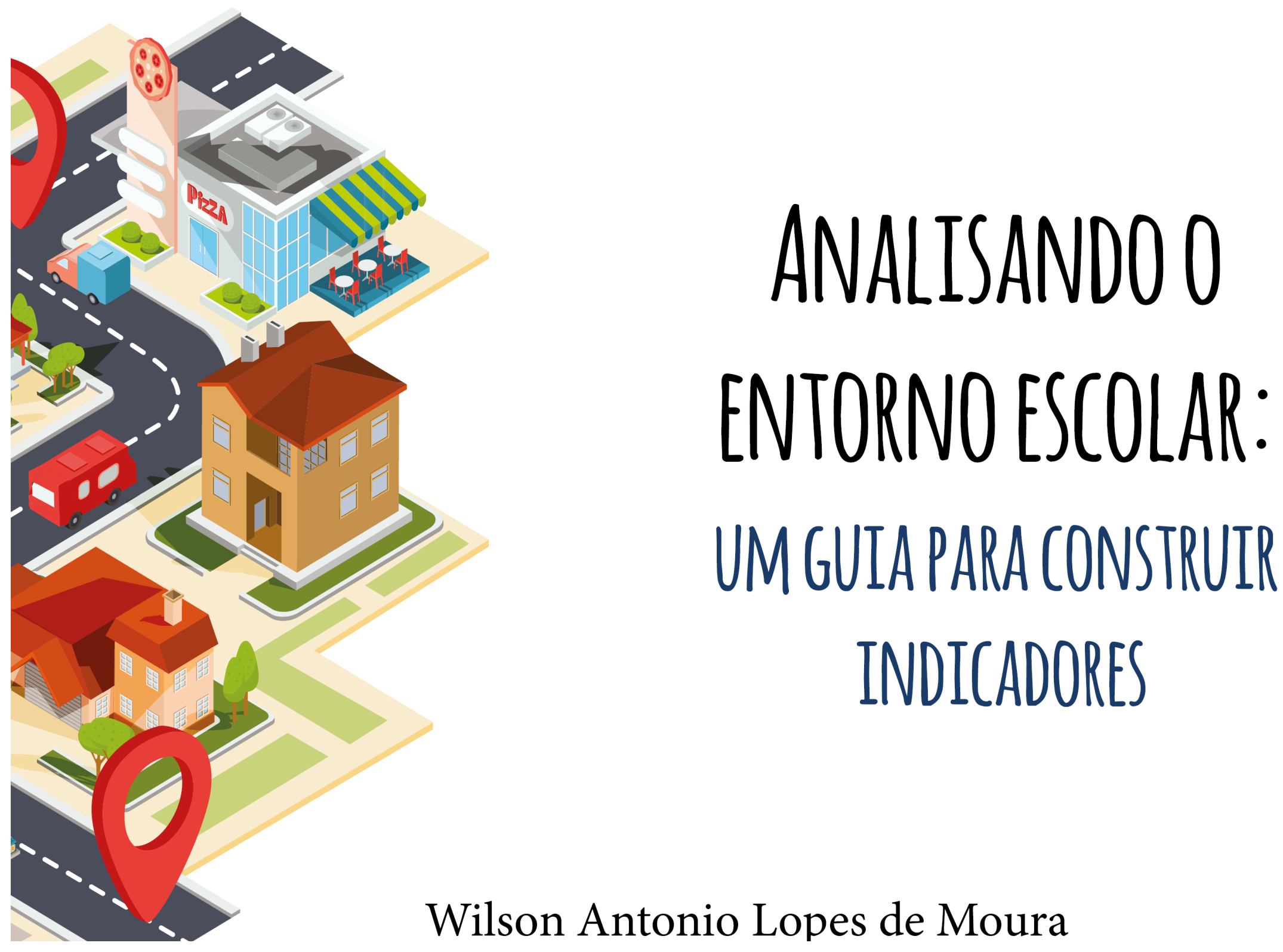




\section{sing \\ PROFCIAMB}

PROGRAMA DE Pós-GRADUAÇÃo EM REDE NACIONAL

PARA O ENSINO DAS CIENCIASAMBIENTAIS

\section{UNIVERSIDADE DE SÃO PAULO ESCOLA DE ENGENHARIA DE SÃO CARLOS Programa de Pós-Graduação em Rede Nacional para \\ Ensino das Ciências Ambientais- PROFCIAMB}

WILSON ANTONIO LOPES DE MOURA

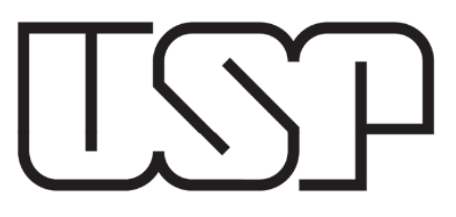

PRODUTO EDUCACIONAL

SÃO CARLOS- SP

2019 
WILSON ANTONIO LOPES DE MOURA

ANALISANDO O ENTORNO ESCOLAR: UM GUIA PARA CONSTRUIR INDICADORES

Produto Educacional apresentado ao Programa de PósGraduação em Rede para o Ensino das Ciências Ambientais - PROFCIAMB, como requisito parcial para obtenção do título de Mestre.

Orientador: Prof. Dr. Luiz Antonio Daniel

\section{SÃO CARLOS-SP}


Acesso à cartilha em formato digital através do site:

https://sites.google.com/usp.br/analisandooentornoescolar/página-inicial

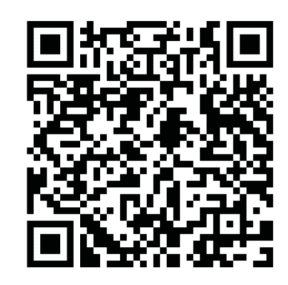

Ficha Técnica

Autoria e diagramação: Wilson Antonio Lopes de Moura

Orientação: Prof. Dr. Luiz Antonio Daniel

Ilustrações

ö freepik.com

Licença Creative Commons

\section{@ $\mathbb{\otimes \Theta}$}

O trabalho Analisando o entorno escolar: um guia para construir indicadores de Wilson Antonio Lopes de Moura está licenciado com uma Licença Creative Commons - Atribuição-NãoComercial-SemDerivações 4.0 Internacional. É um produto educativo e não tem fins lucrativos. 


\section{AGRADECIMENTOS}

Aos alunos e gestores da Escola Muncipal de Educação Básica Professor Erotides de Campos da cidade Charqueada/SP

Ao Professor Doutor Luiz Antonio Daniel
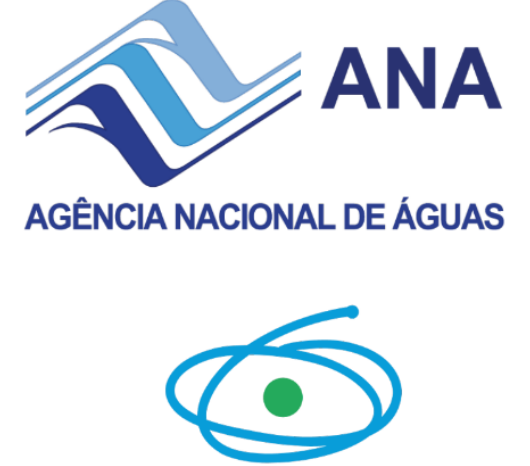

CAPES
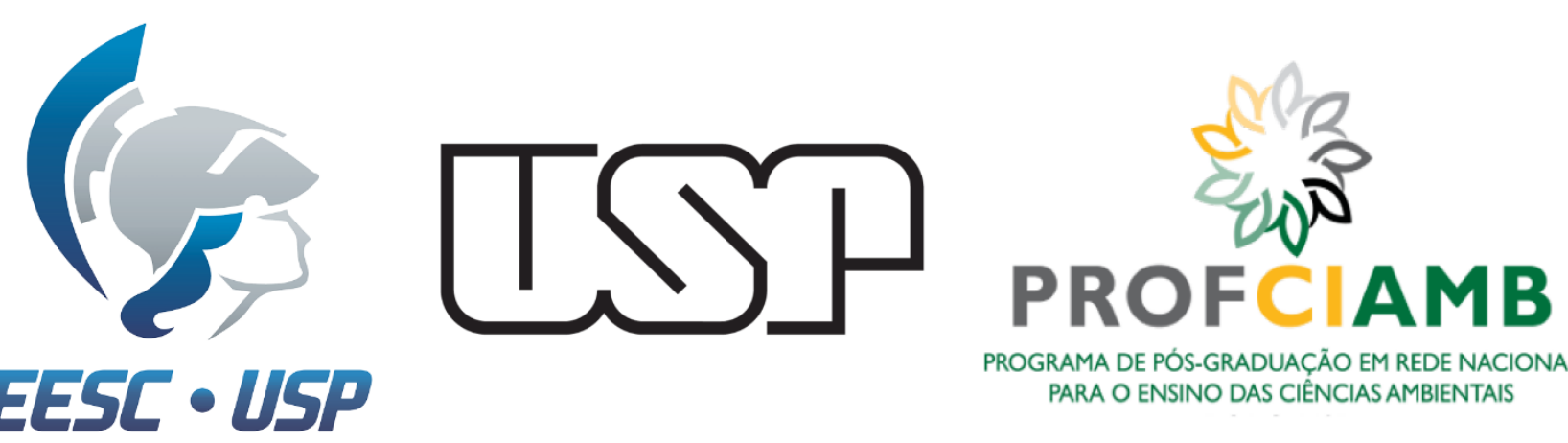

PROGRAMA DE PÓS-GRADUAÇÃO EM REDE NACIONAL PARA O ENSINO DAS CIÊNCIAS AMBIENTAIS 
Você já parou para pensar no que poderia ser feito para melhorar o lugar onde você vive? E em quem poderia ajudar nessa difícil tarefa? $\mathrm{Ou}$, até mesmo, quais poderiam ser as formas de você propor as mudanças nesse lugar?

Nesta cartilha feita para professores e alunos, propomos uma análise do entorno escolar com a finalidade de gerar indicadores de desenvolvimento sustentável para essa área onde a escola está inserida.

Se, por acaso, você já achou estranho e até complicado alguns termos até aqui, não precisa ficar preocupado, pois iremos realizar diferentes atividades para que você possa compreendê-los e ajudar na construção de uma sociedade melhor!

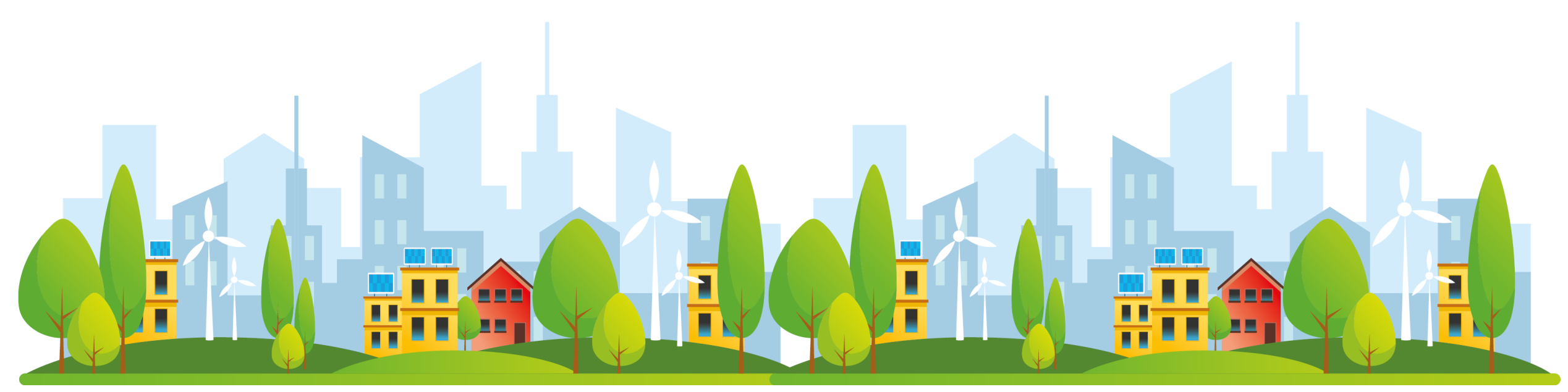




\section{CAMINHOS}

No livro "Alice no país das maravilhas" de Lewis Carroll, há uma conversa que serve como início de nossas discussões:

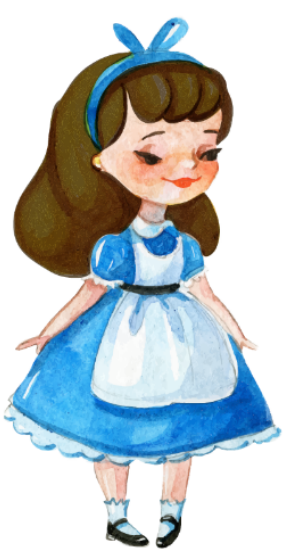

- O senhor poderia me dizer, por favor, qual o caminho que devo tomar para sair daqui?

- Isso depende muito de para onde você quer ir, respondeu o Gato;

- Não me importo muito para onde, retrucou Alice.

- Então não importa o caminho que você escolha”, disse o Gato.

- Contanto que dê em algum lugar, Alice completou.

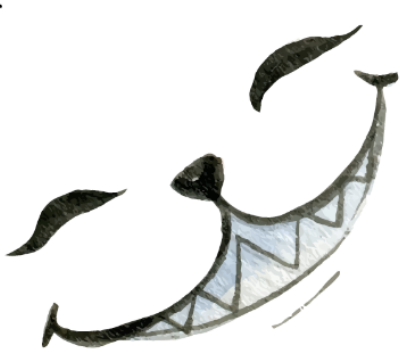

- Oh, você pode ter certeza que vai chegar se você caminhar bastante, disse o

Gato.

Sendo assim, procure pensar sobre quais os caminhos a percorrer. Qualquer caminho serve? Onde queremos chegar?

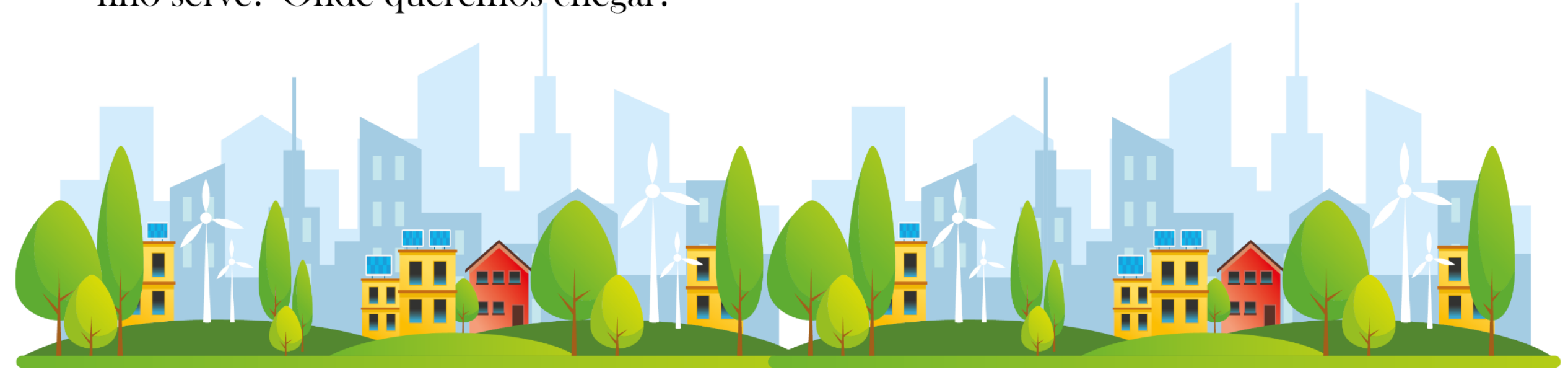


Para responder a essas perguntas, propomos cinco caminhos que nos auxiliem a realizar uma análise do entorno escolar e gerar melhorias nas condições encontradas! São eles:

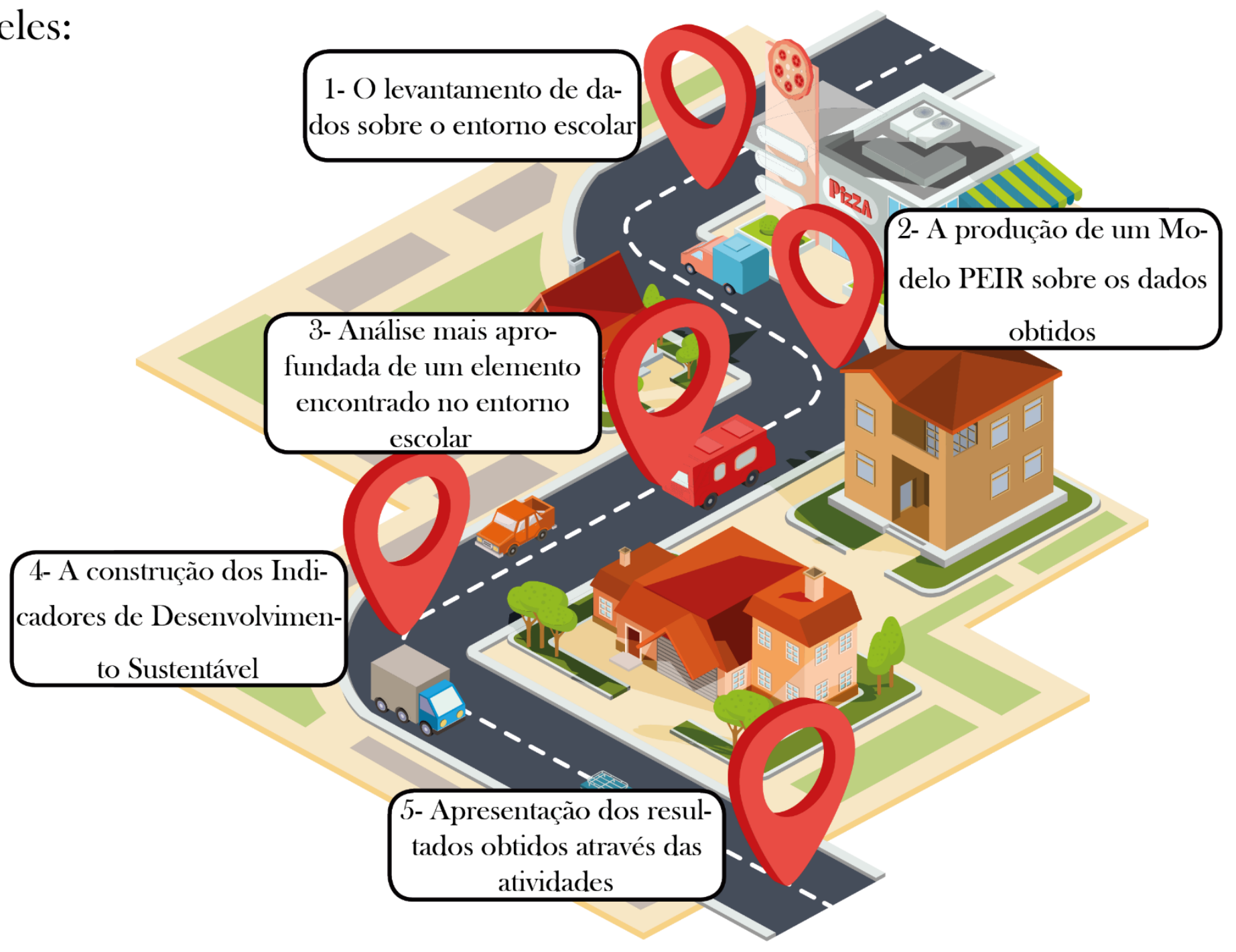


Só mais um pouquinho e já começaremos! Antes das atividades é preciso que você entenda como este guia foi organizado.
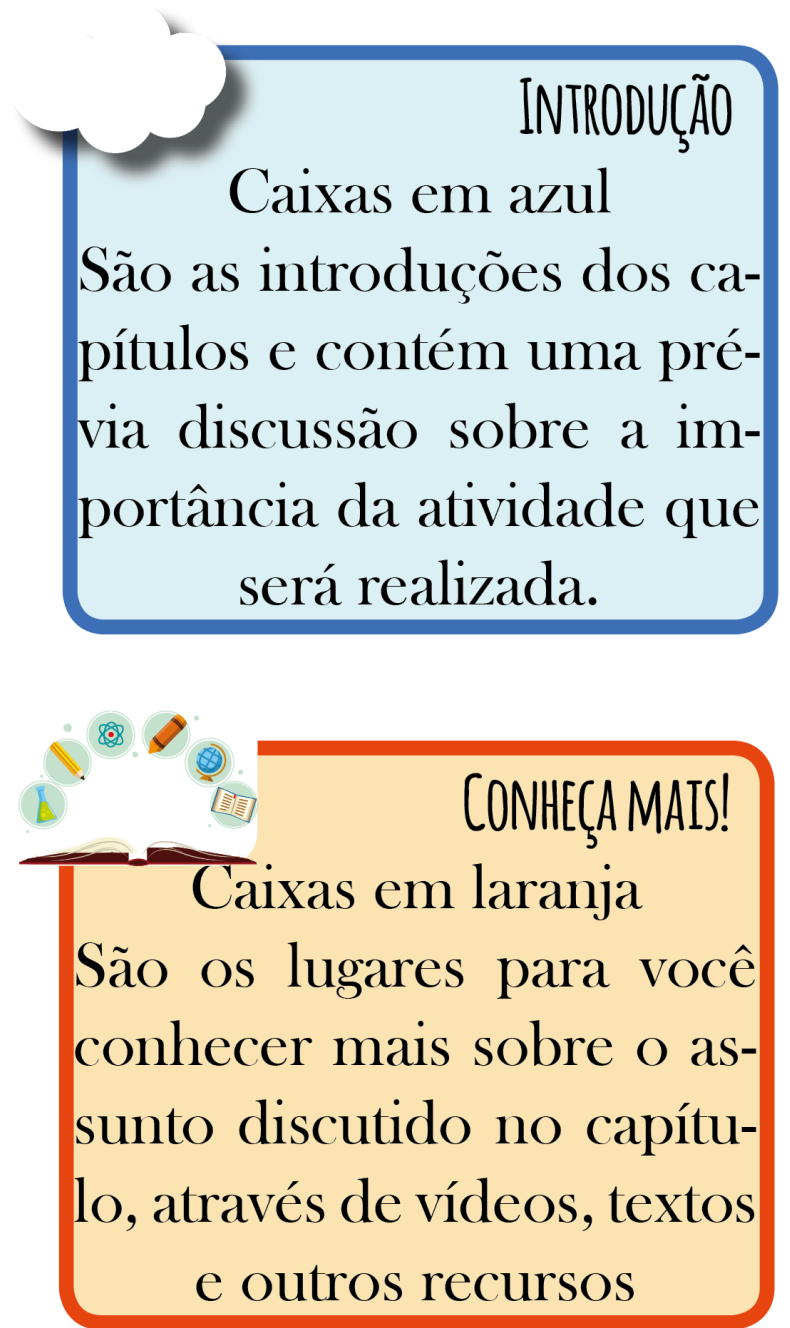
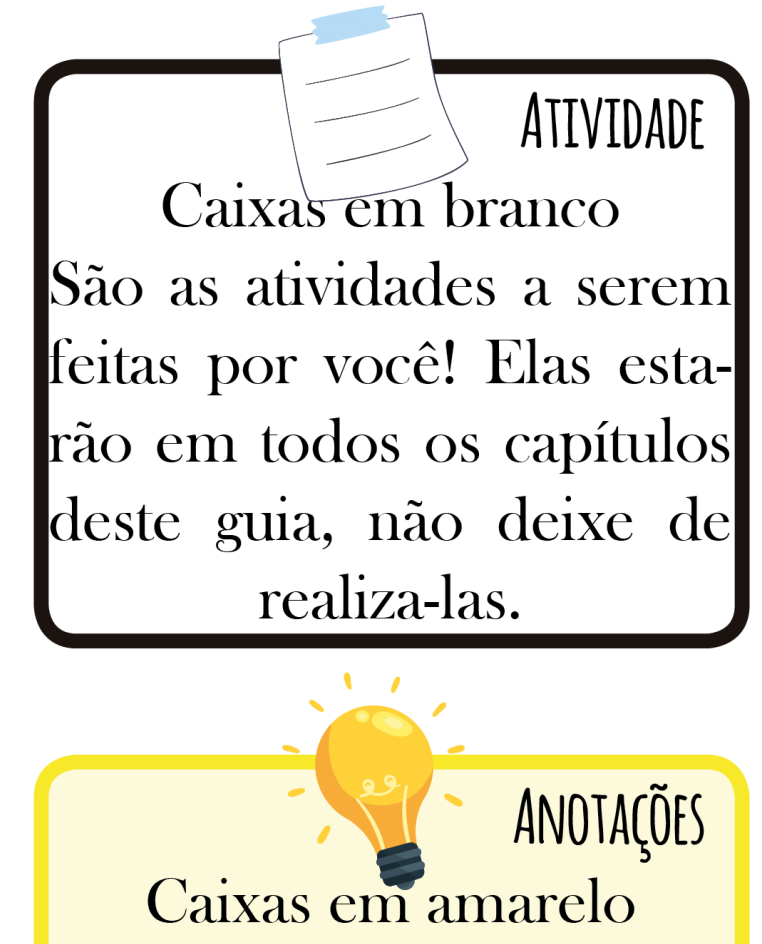

São espaços de anotações, onde você pode ficar a vontade para escrever ou desenhar o que quiser, sempre que precisar!

\section{CONCETTOS \\ Caixas em verde}

São os conceitos essenciais para você entender e desenvolver as atividades. Eles são uma fonte de consulta muito importante.

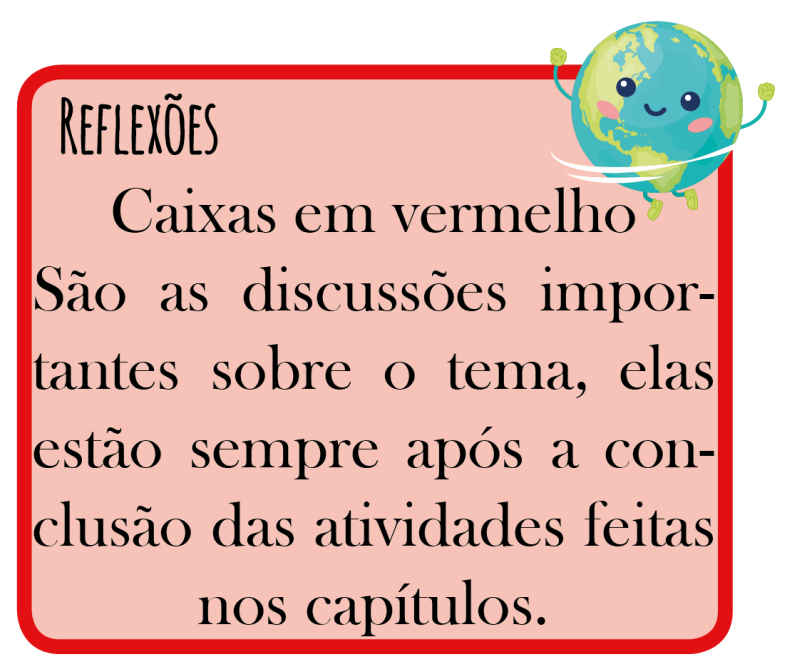

Após conhecer o guia: Vamos nessa então! 


\section{SUMÁrí}

1- Levantamento de informações sobre o entorno escolar............................................11

2- Organização das informações segundo o Modelo PEIR.......................................19

3- Produção do Kit de análise da água...............................................................23

4- Construção dos Indicadores de Desenvolvimento Sustentável..............................31

5- Apresentação dos resultados obtidos através das atividades.................................35

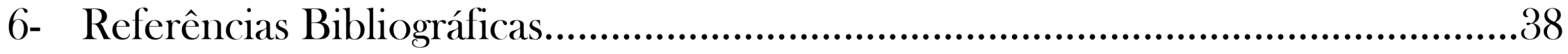

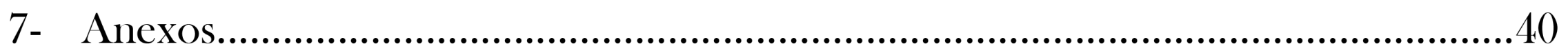

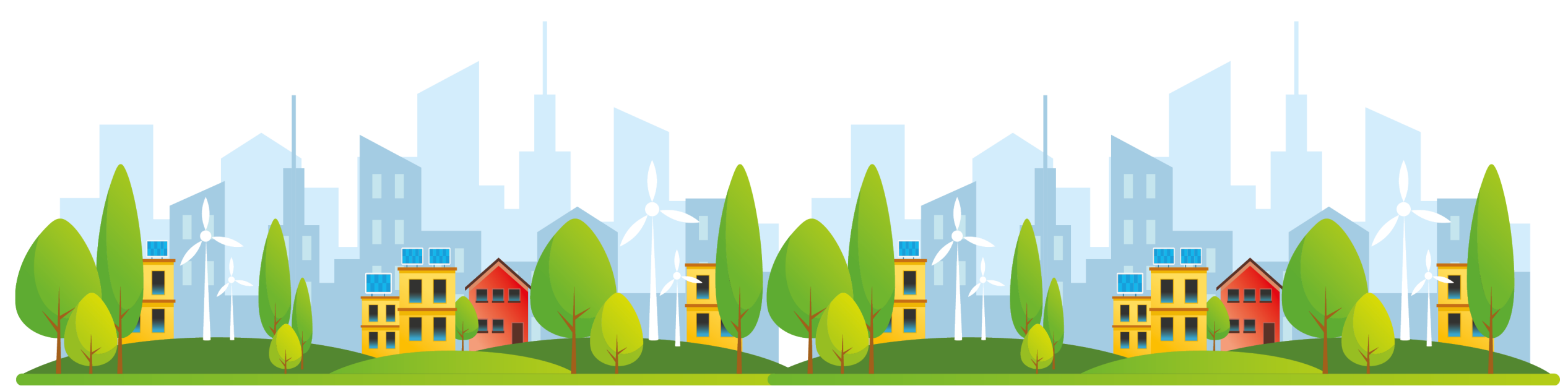




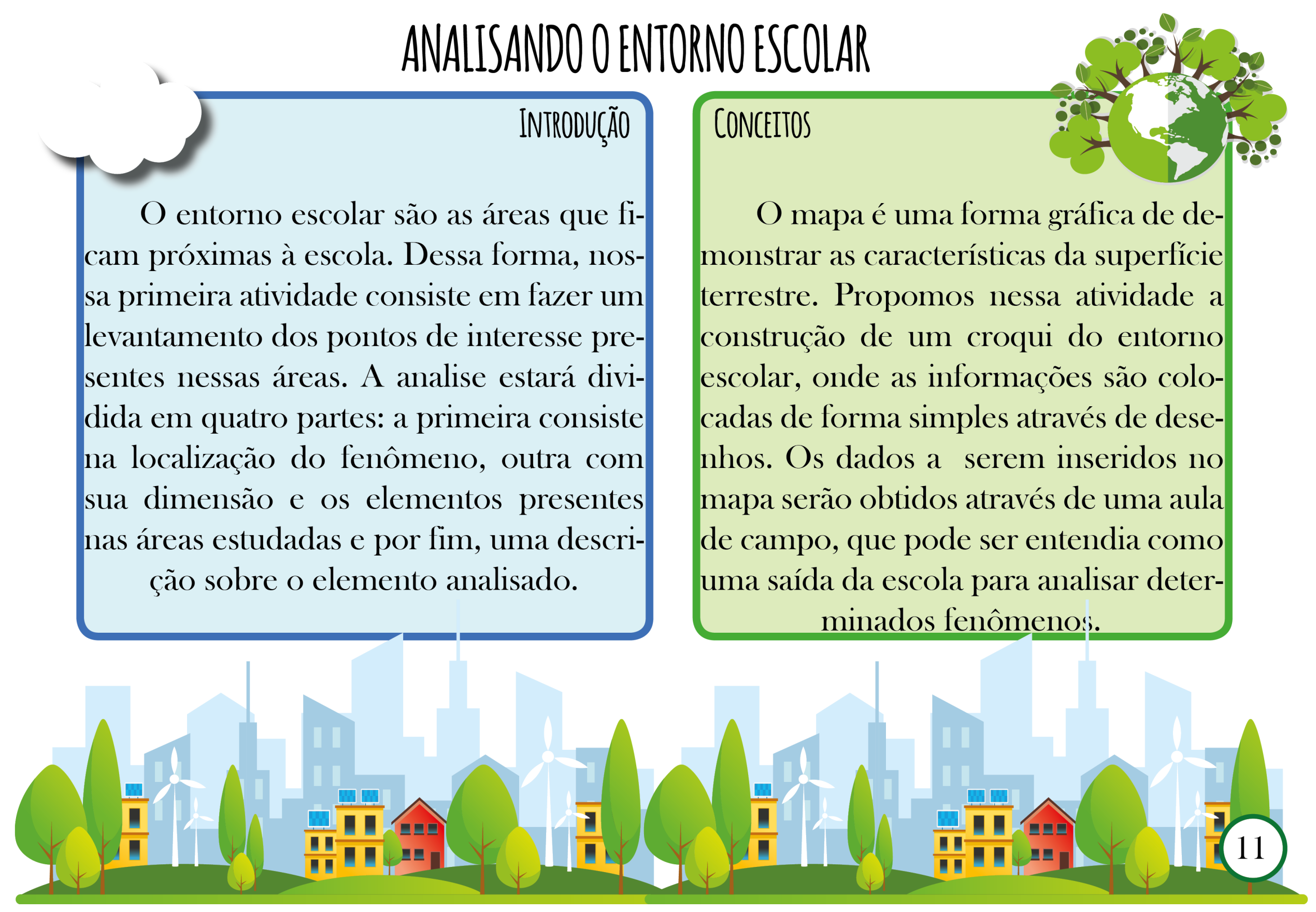




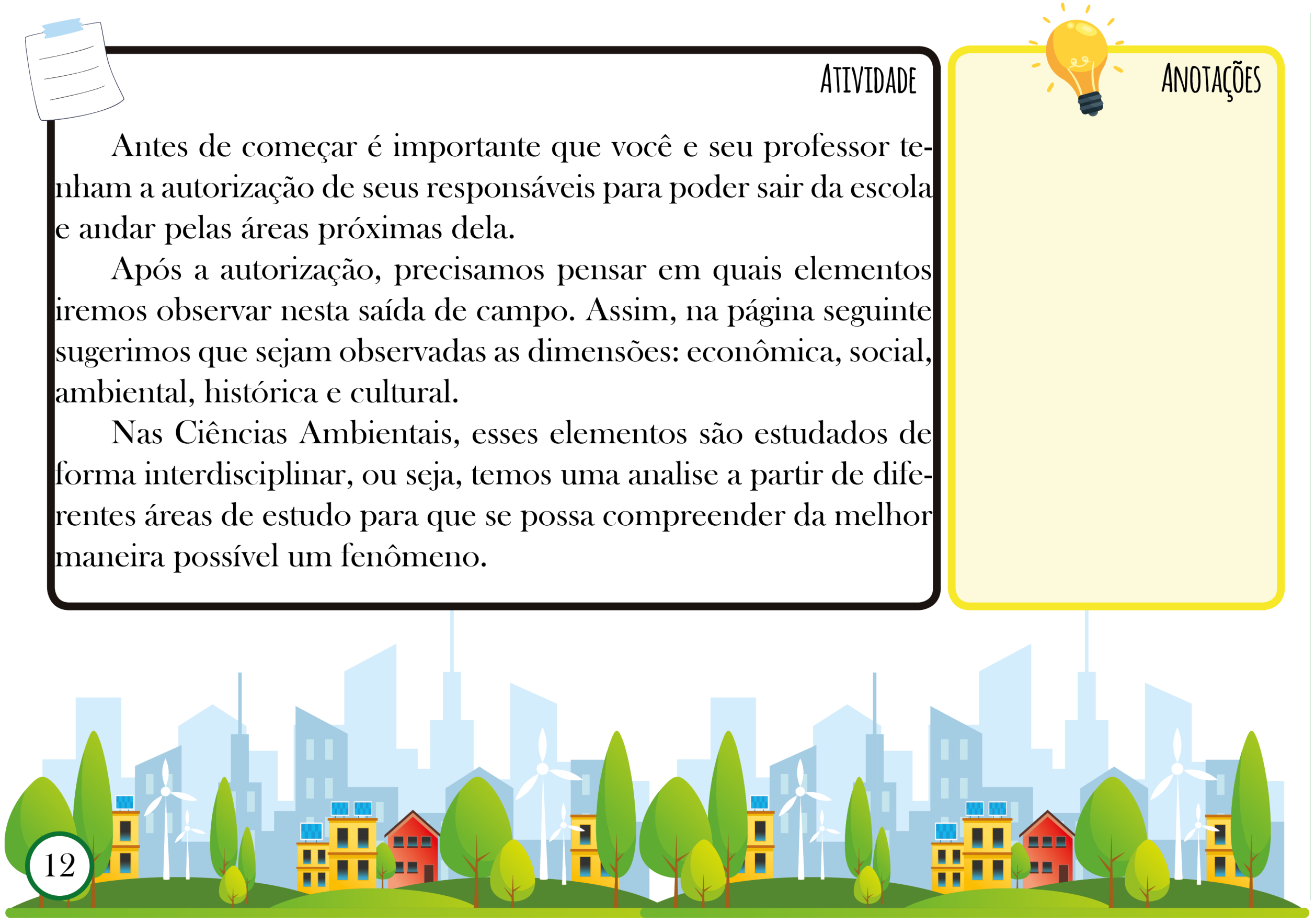




\section{Sociais: espaços pú-}

blicos como praças, escolas, hospitais, postos de saúde, parques, en-

Econômicos: comércio, indústria, agricultura, serviços

Social $\div$ tre outros.
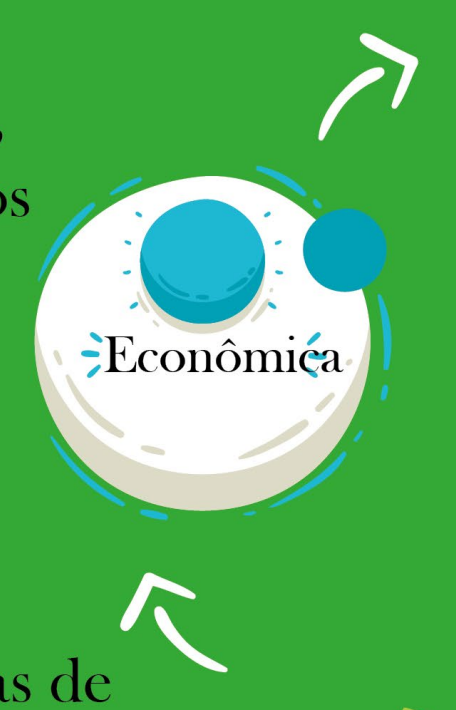

Ambientais: áreas de preservação, rios, florestas, áreas verdes; problemas ambientais como lixo, entulho, queimadas, poeira, poluição do ar, terra, água, despejo

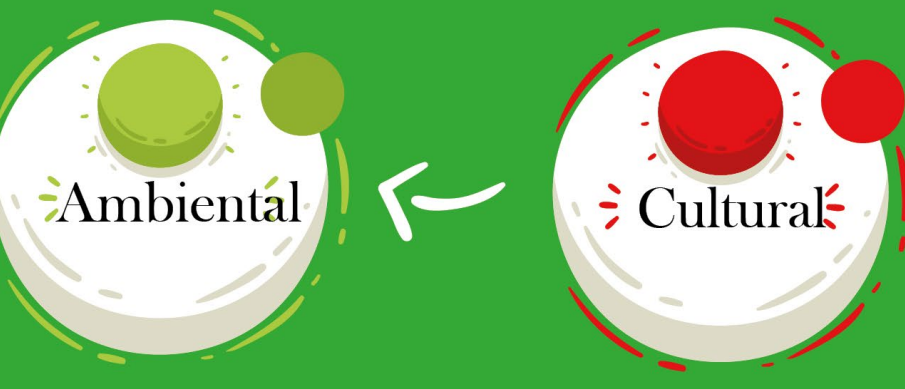
de esgoto, entre outros. 
Agora precisamos organizar a saída a campo!

Para isso você deverá desenhar na página 16 o mapa da área onde será feita a observação.

Combine com o professor qual será o caminho a ser percorrido.

Com a rota em mãos, forme um grupo com quatro alunos: um fica responsável por marcar os pontos no mapa, dois por dizer quais são os elementos observados e o último fica encarregado de fotografar os locais.

Atenção: Na saída a campo, fique próximo ao professor, faça anotações no mapa feito por você.

Dica: procure também ao tirar as fotos, nomeá-las para que fique mais fácil de lembrar dos locais onde você visitou.

Faça a descrição do elemento encontrado, buscando o maior número de detalhes e anotoando-os na página 17 , como no exemplo a seguir:

\begin{tabular}{|c|c|c|c|}
\hline PONTO & DIMENSÃO & ELEMENTO & DESCRICẼO \\
\hline 1 & Ambiental & Lixo & $\begin{array}{l}\text { Lixo acumulado na rua, } \\
\text { como papeis, plásticos, res } \\
\text { tos de comida, metais. Os } \\
\text { moradores dizem que não } \\
\text { há coleta de lixo ou recicláa } \\
\text { veis durante a semana. }\end{array}$ \\
\hline
\end{tabular}


Depois de você terminar a coleta de informações, vamos juntar os dados coletados em um único mapa que o professor irá fazer para a sala.

Antes de reunir os dados, os grupos devem buscar enumerar os elementos que foram comuns e criar uma legenda para o mapa. A legenda pode ser desenhada na folha em anexo, presente na página 43. Para não desenhar as mesmas legendas, cada grupo pode ficar responsável por uma dimensão.

Com as legendas prontas, insira-as no mapa geral da sala, nos locais onde os elementos foram identificados.

Não se esqueça de dar um título para o mapa!

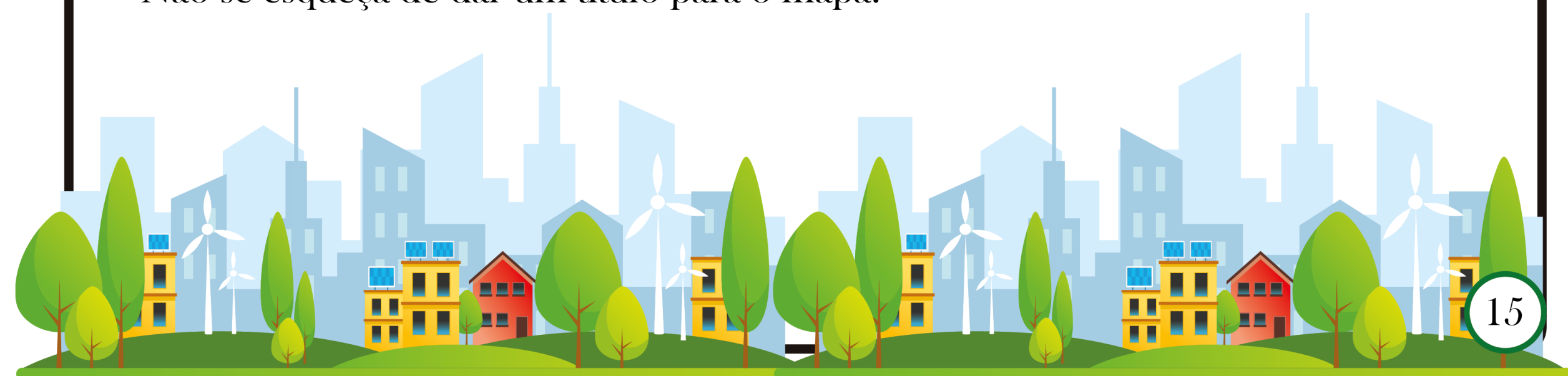


Mapa do Entorno Escolar 


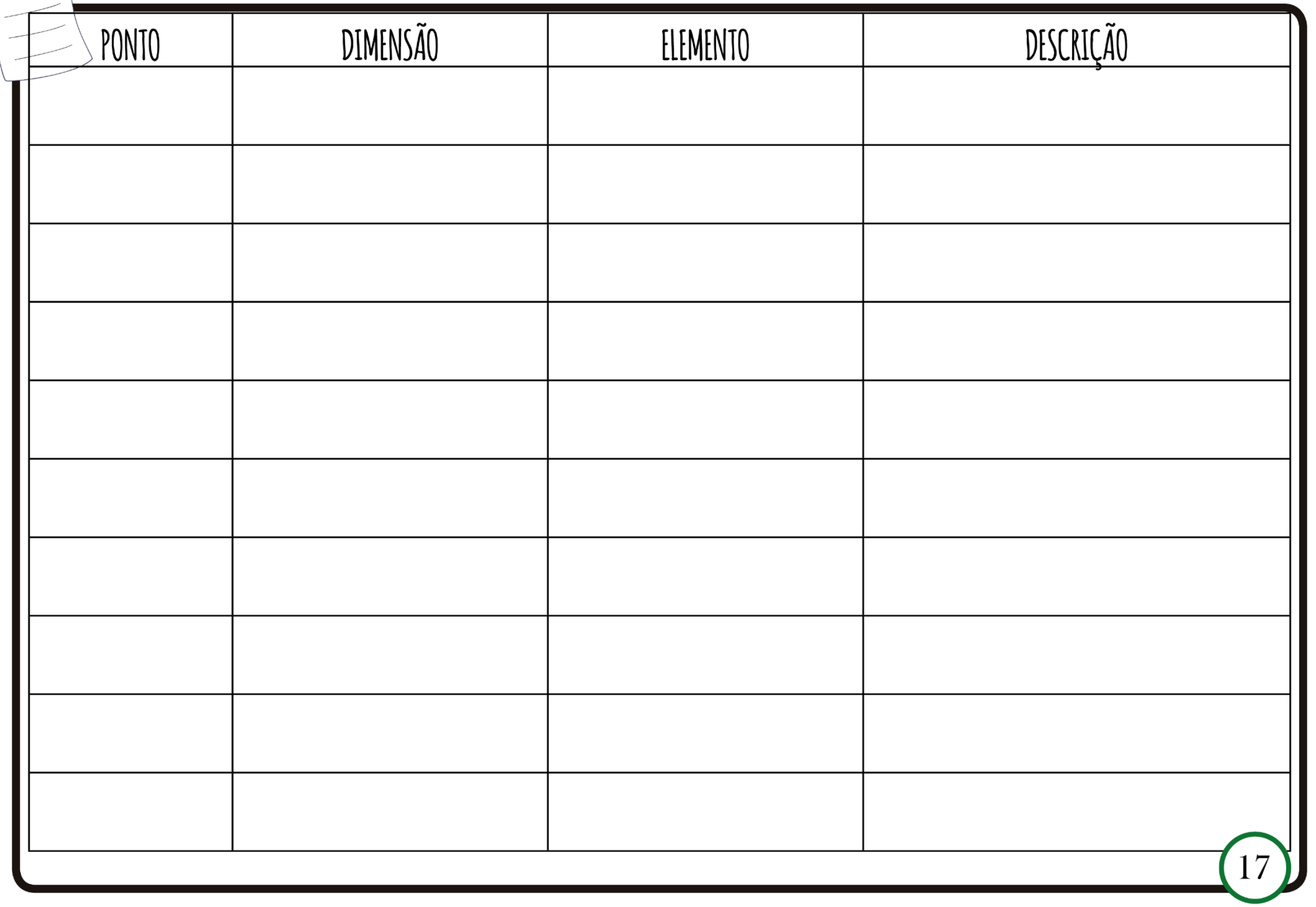


O mais importante neste primeiro capítulo é que você comprrenda duas ideias principais:

- Quando se analisa o meio ambiente é imprescindível que você compreenda que são diversas as dimensões que devem ser analisadas: a social, ambiental, histórica, cultural e econômica. Mesmo assim, não basta analisar de forma individual essas dimensões, elas precisam estar interligadas e principalmente, de forma interdisciplinar, ou seja, integrando diferentes disciplinas, tanto escolares como científicas.

- Para que sua análise apresente uma ótima descrição do local, você precisa sempre se atentar aos detalhes, por isso, conversar com moradores do lugar é de grande importância, pois eles têm muito a contar sobre ele.

CRIESEU PRÓPRIO MAPA COMOGOOGLEMAPS

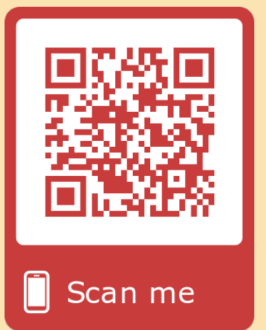

CONHEÇA O BIOMAPA

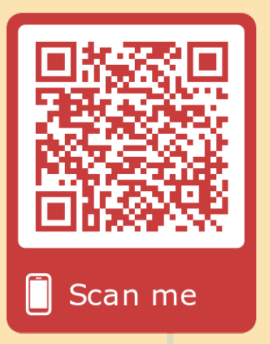




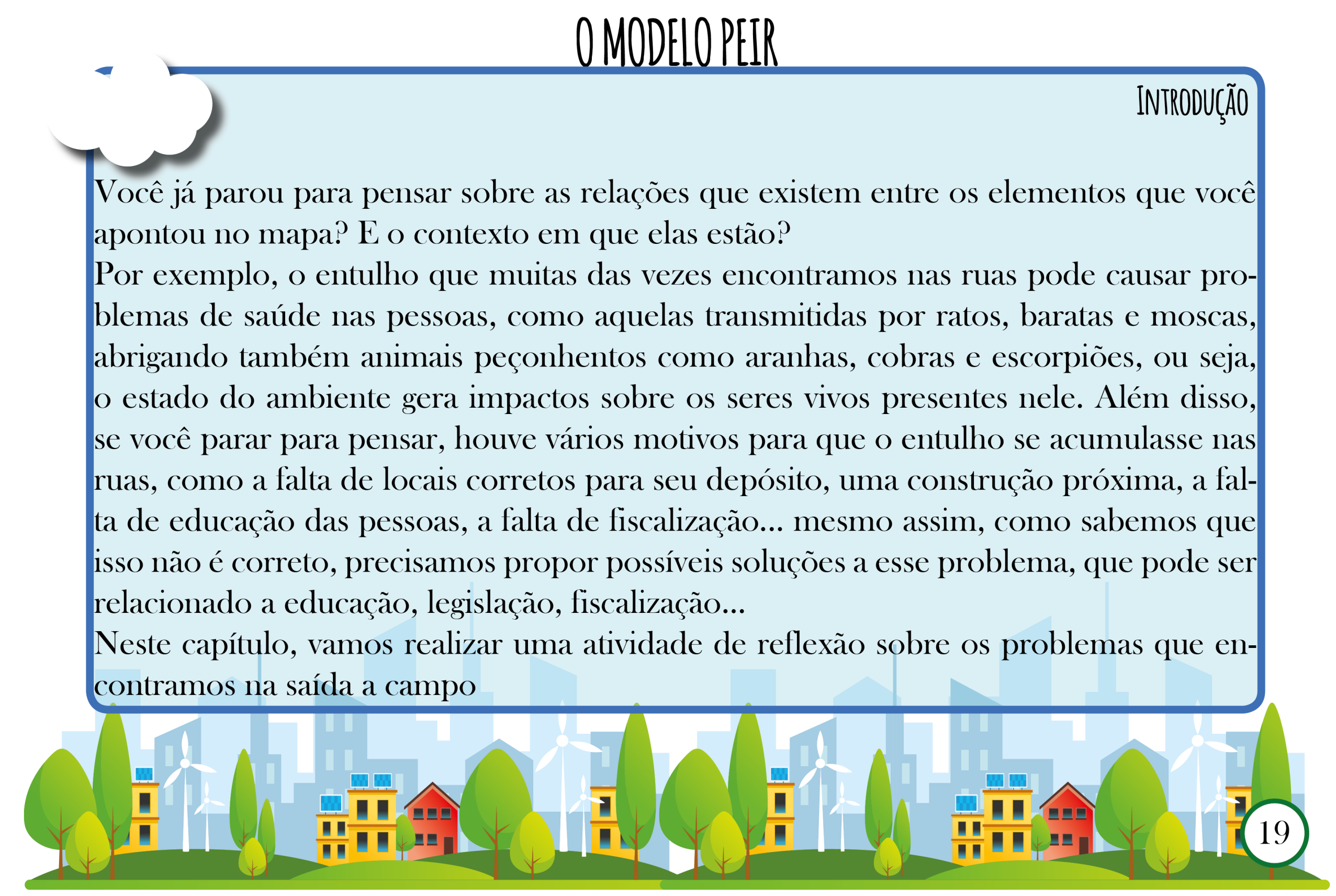




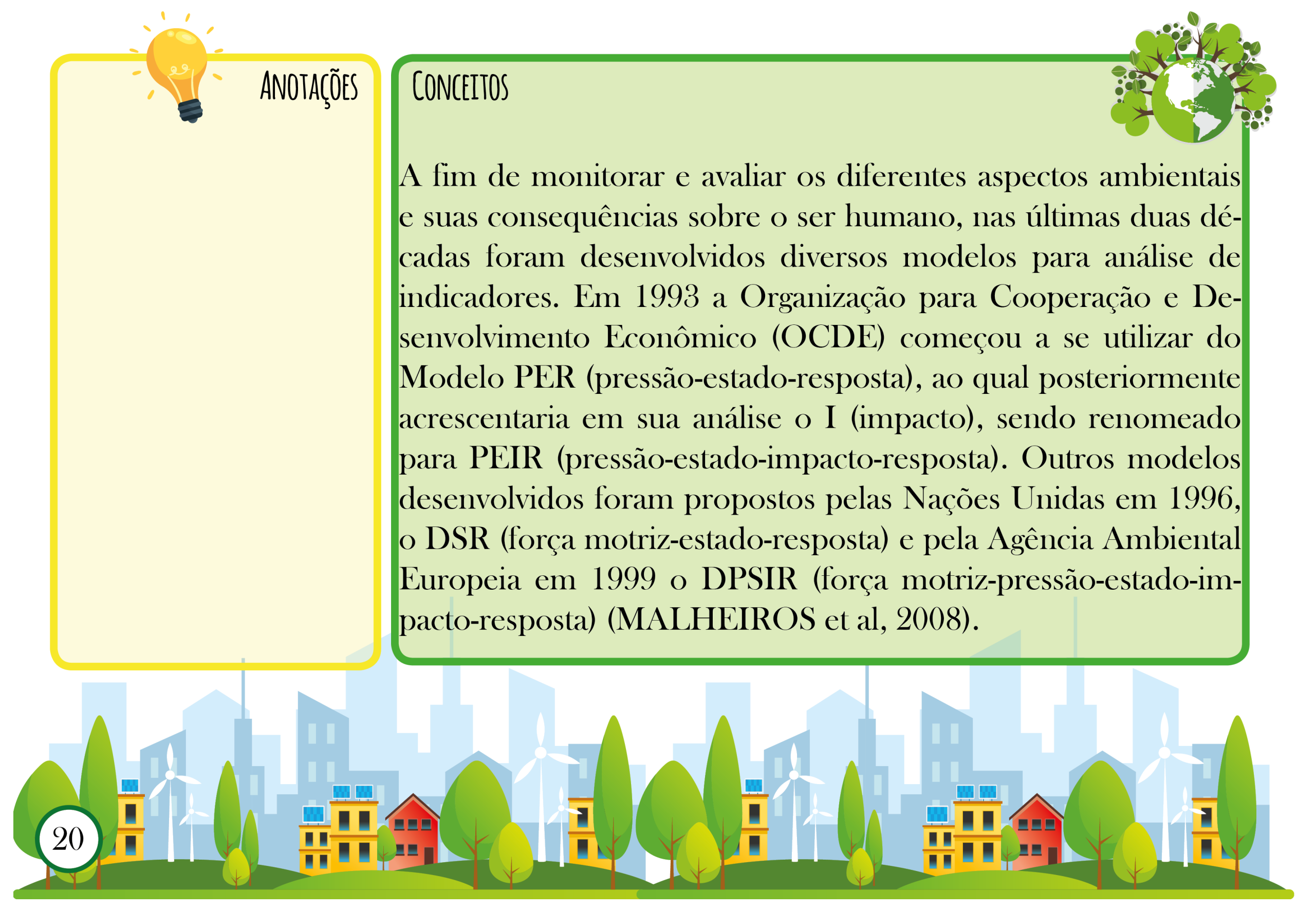


Preencha o quadro a seguir utilizando o Modelo PEIR, busque acrescentar o maior número de detalhes possíveis, imaginando as relações entre eles.

\begin{tabular}{|l|l|l|l|}
\hline PRESSÃO & ESTADO & IMPACTO & RESPOSTAS \\
\hline & & & \\
& & & \\
& & & \\
& & & \\
\hline
\end{tabular}




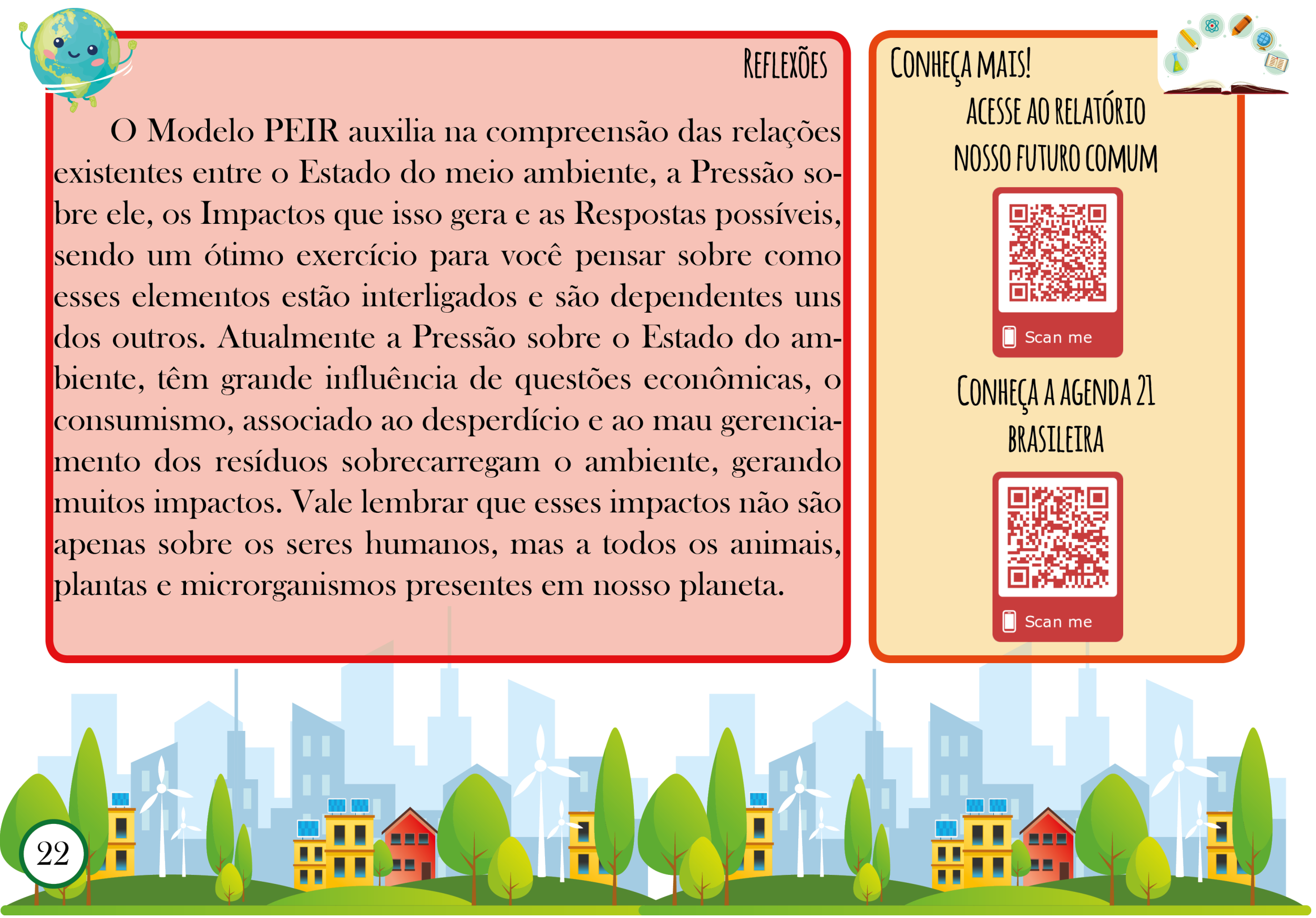




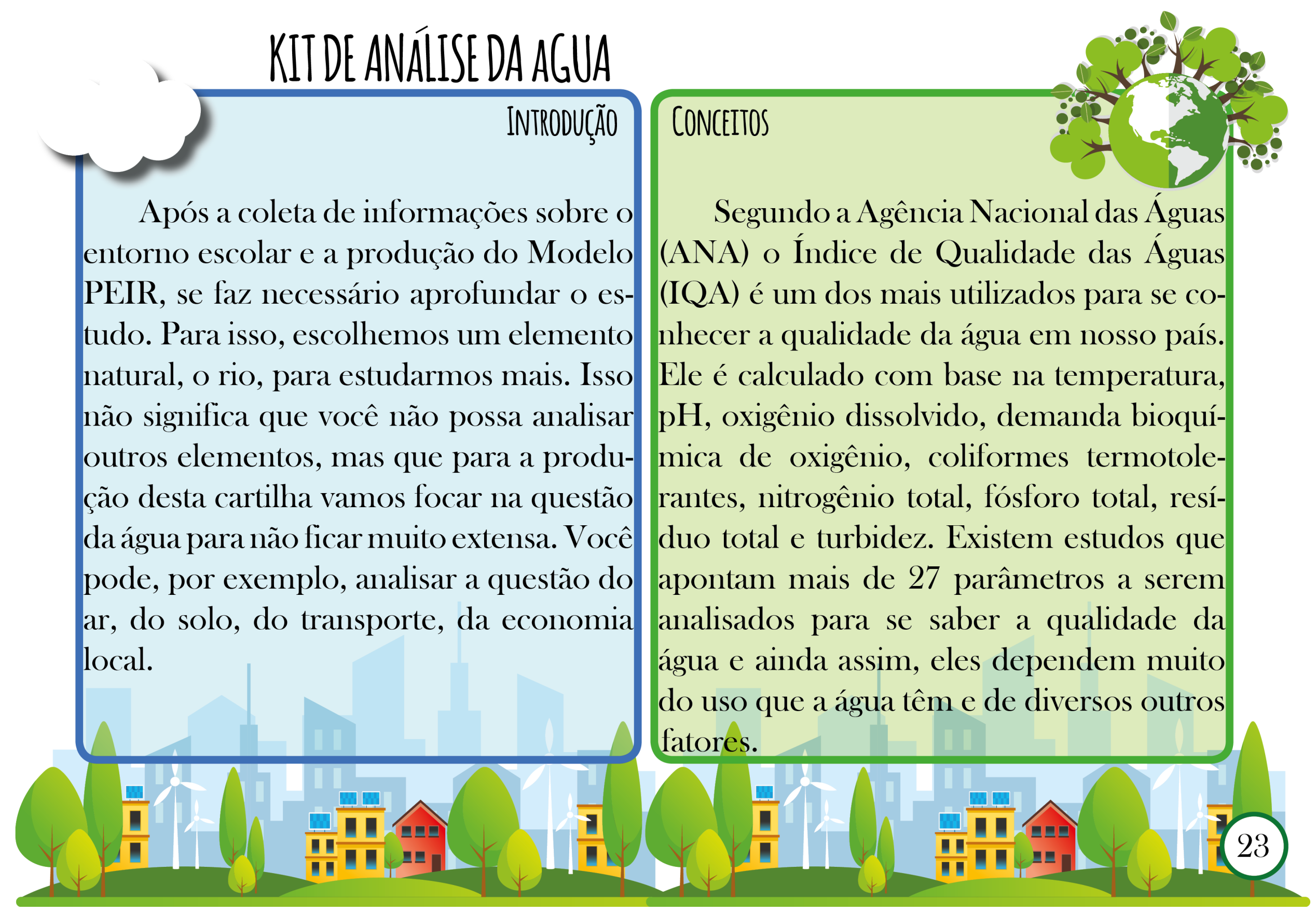




\section{MATERIAS PARA MONTAR OKIT}

\section{Caixa}

1 caixa de sapato

1 pedaço de papelão $40 \mathrm{~cm} x 12 \mathrm{~cm}$ aproximadamente

1 tesoura sem ponta

1 cola

1 folha com escalas (anexo $\mathrm{x}$ )

1 folha de anotações dos dados (anexo x)

1 garrafa pet de $600 \mathrm{ml}$

$2 \mathrm{~m}$ de barbante

Lápis, caneta e papel para o acabamento

O material das páginas 40, 41 e 42 presentes no fim deste guia.
Turbidímetro

1 mangueira transparente com $1 \mathrm{~m}$ e 25

$\mathrm{cm}$ de diâmetro

1 cap para mangueira

1 trena

1 canetinha

4. tubinhos transparentes

1 teste de $\mathrm{pH}$

1 teste de Amônia

4 frascos de remédio (devem estar limpos e secos) 


\section{Caixa - Armazenando os instrumentos de análise da ÁGua}

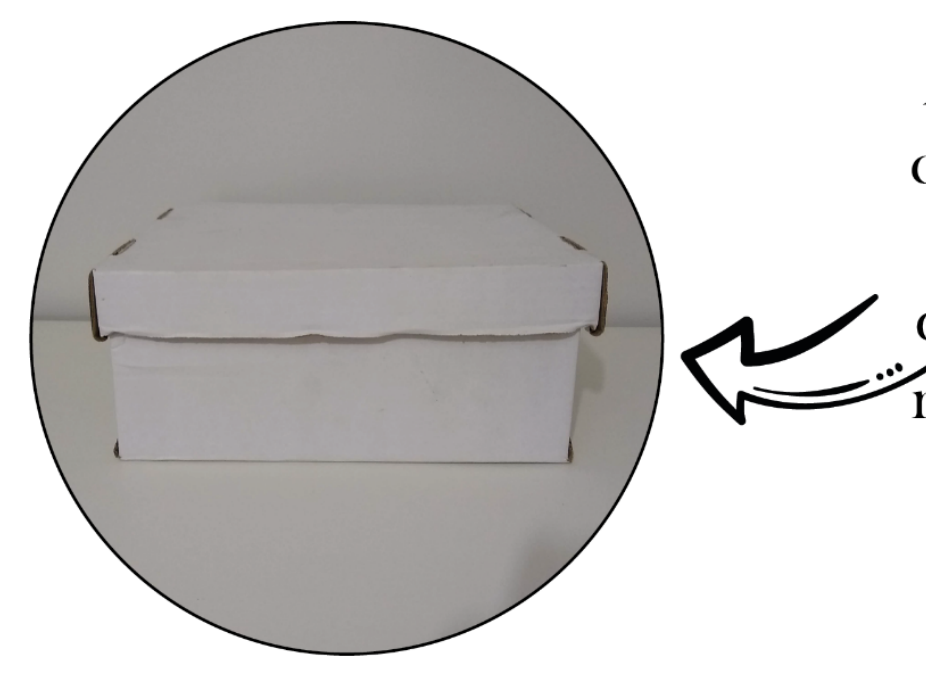

A caixa de sapato será o local onde serão armazenados os instrumentos de análise de nosso kit. Você deve primeiramente decorá-la como quiser.

Ao final desta etapa o objetivo é que você deixe a sua caixa desse jeito por dentro!

Lembre-se de colocar as folhas dentro que estão no fim do guia no kit, para que possa realizar as anotações!

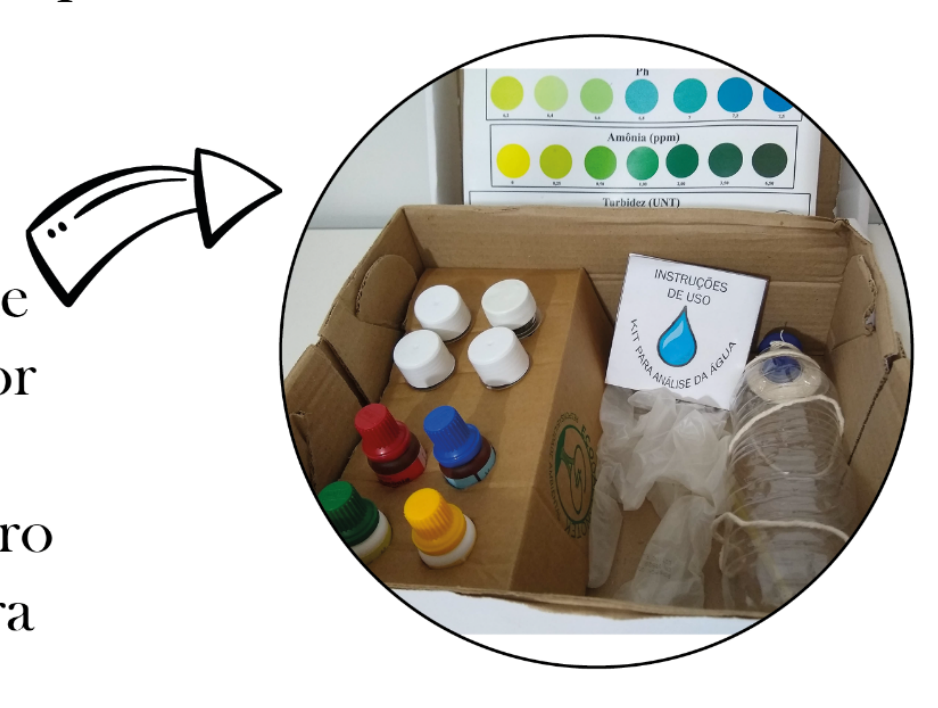




\section{POR deNTrO dACAIXA}

Após decorar a caixa, faça uma tira de papelão nas medidas de sua caixa, essas medidas são aproximadas, o mais correto é você medir a sua caixa e fazer conforme ela.
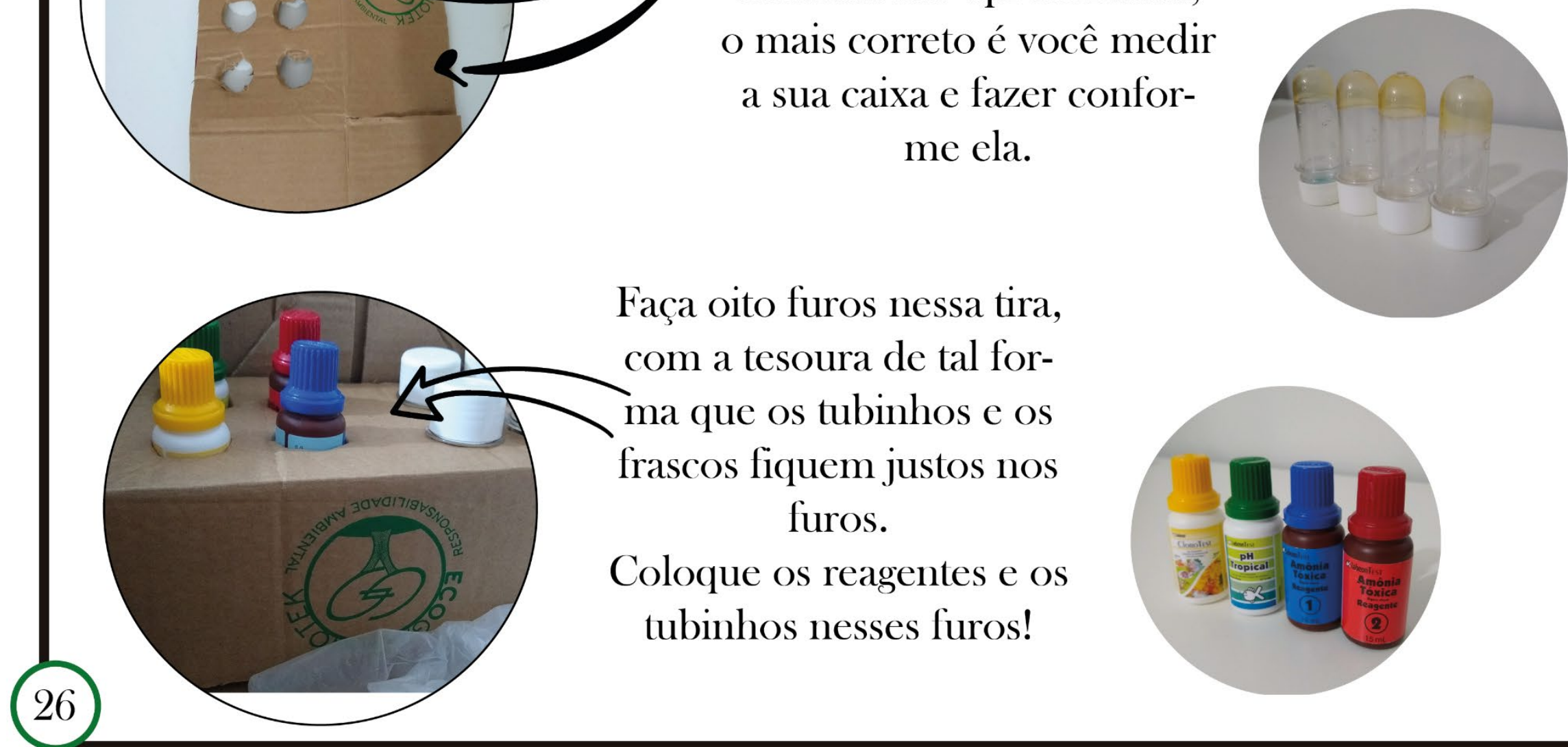


\section{TURBDímeETro OU TUBODÍMETRO}

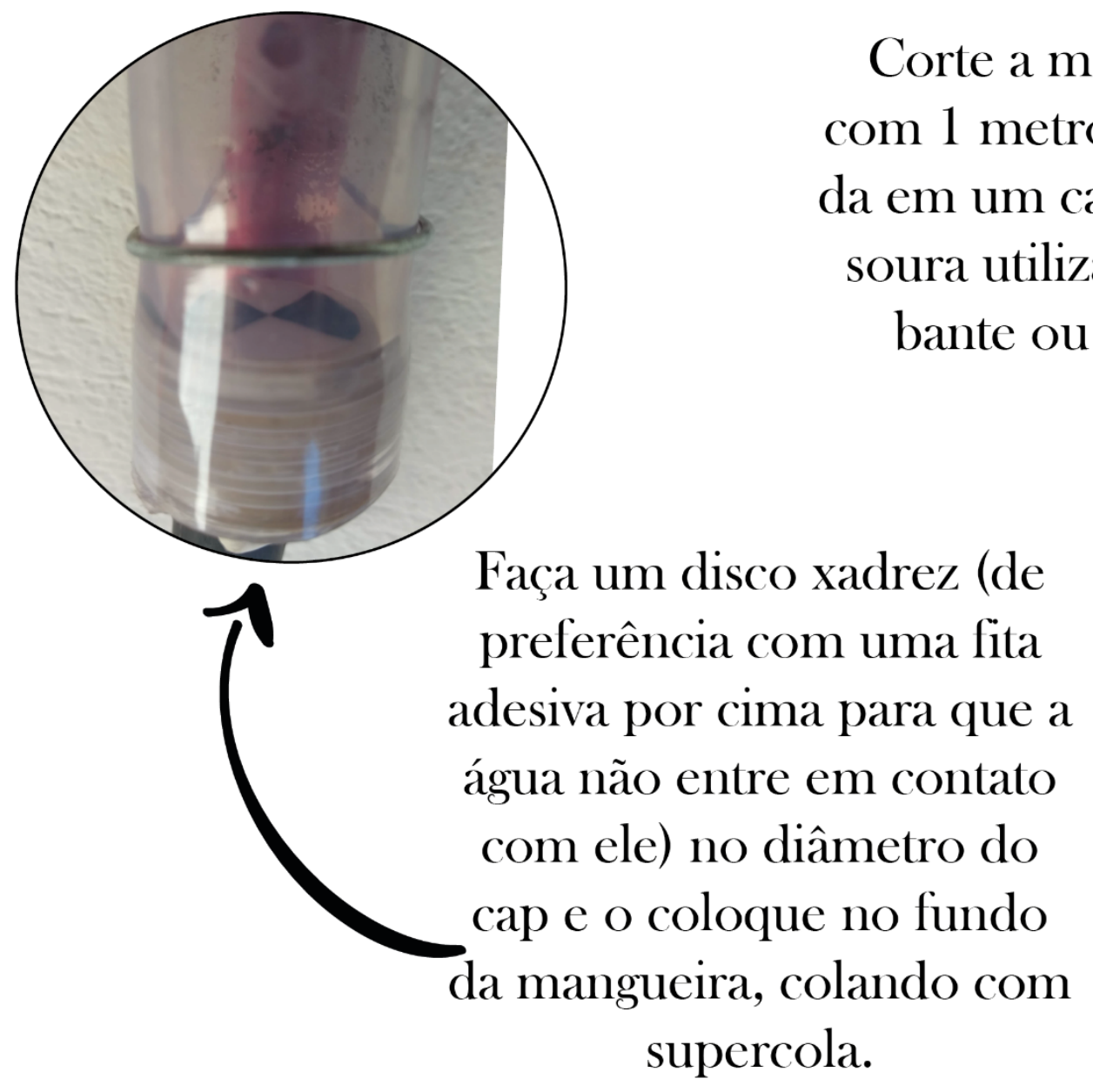

Corte a mangueira e a prenem um cabo de vasura utilizando barbante ou arame.

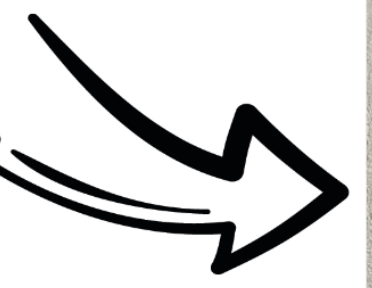

Faça um disco xadrez (de preferência com uma fita agua nao entre em contato água não entre em contato com ele) no diâmetro do cap e o coloque no fundo da mangueira, colando com supercola. 


\section{TURBDímeETro OU TUBODÍMetro}

Você deve deixar a mangueira bem reta para que possa conseguir olhar o disco que você fez no fundo, isso é muito importante para conseguir analisar a turbidez da água

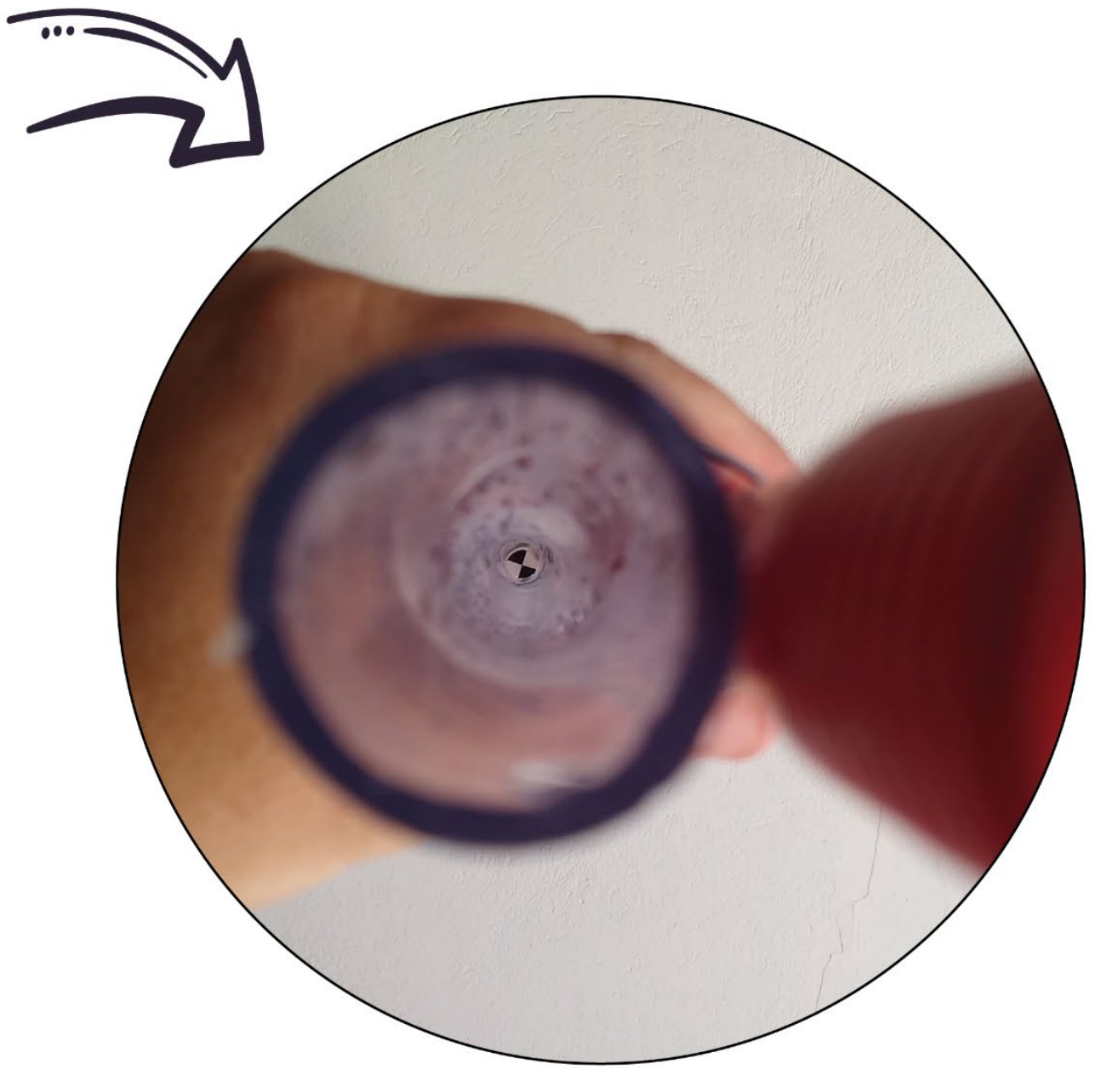




\section{USANDOO KIT}

Em um rio próximo a escola ou até mesmo com a água da escola, faça a coleta de pelo menos 4 amostras de locais diferentes que serão analisadas em

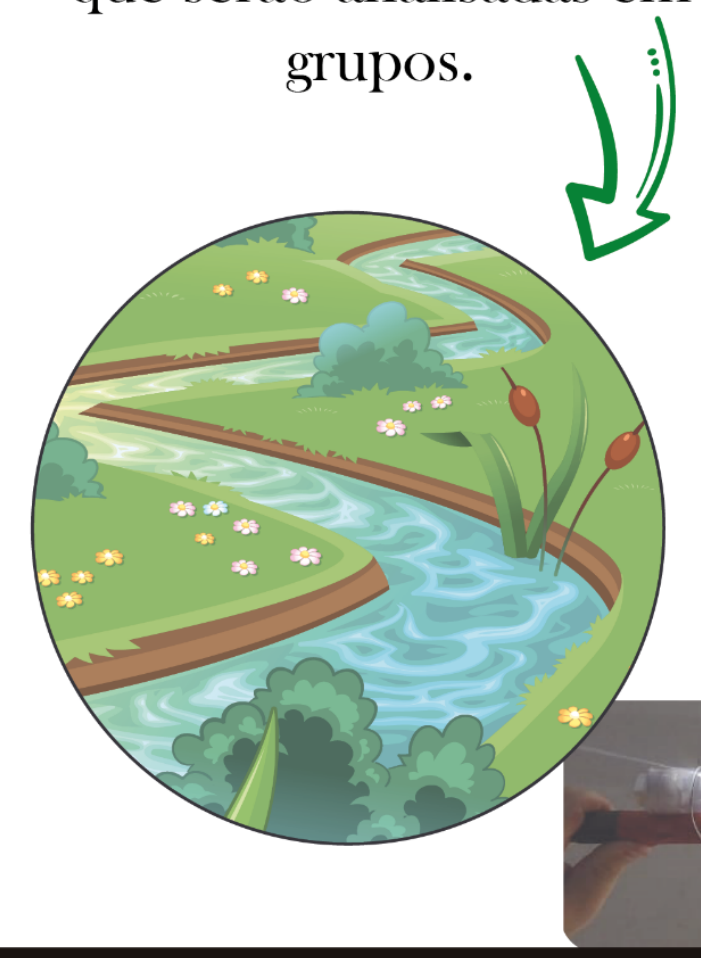

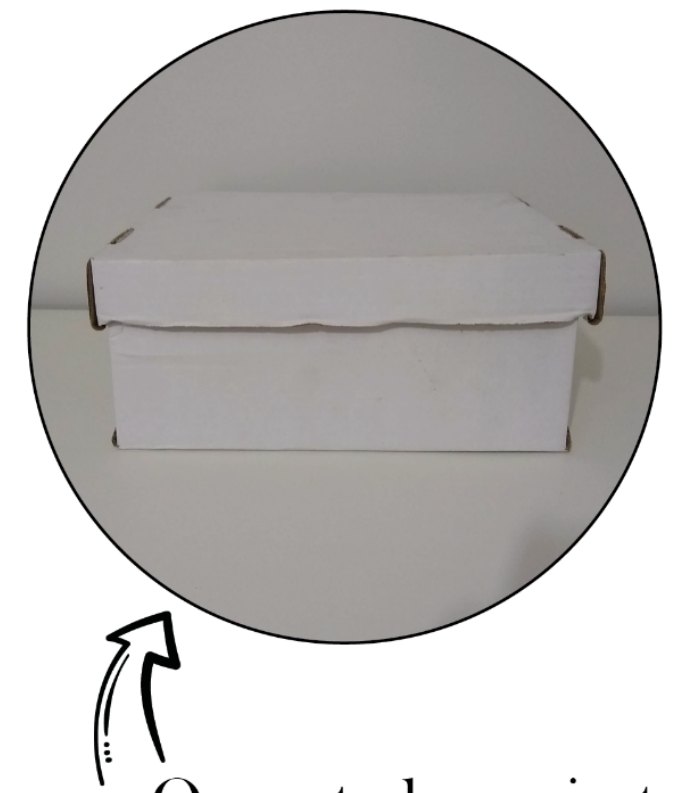

Quase todos os instrumentos montados anteriormente vão dentro da caixa exceto o turbidímetro, que é muito grande.
Faça a análise conforme as instruções (anexo 40). Anote os dados na folha de dados, preenchendo todos os campos.

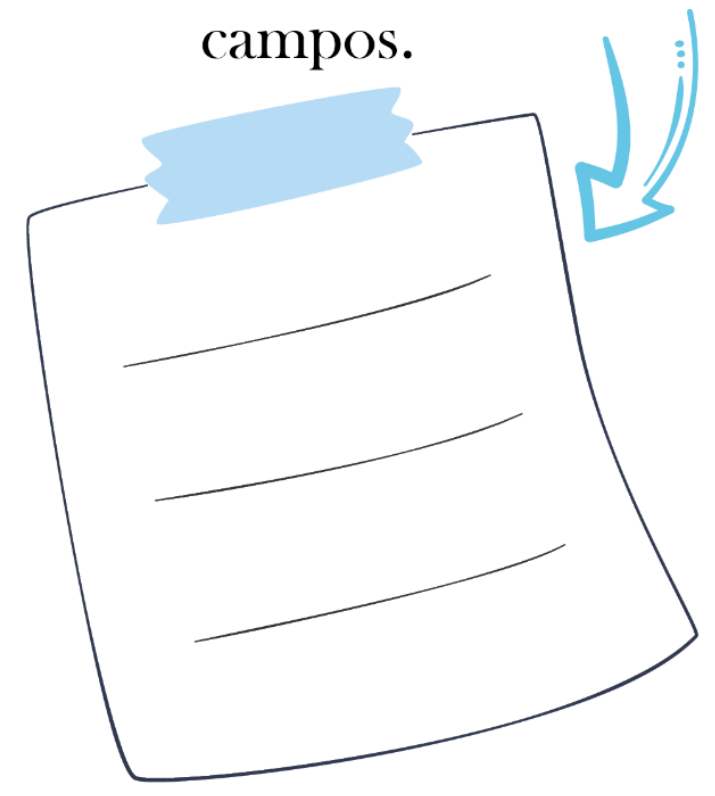




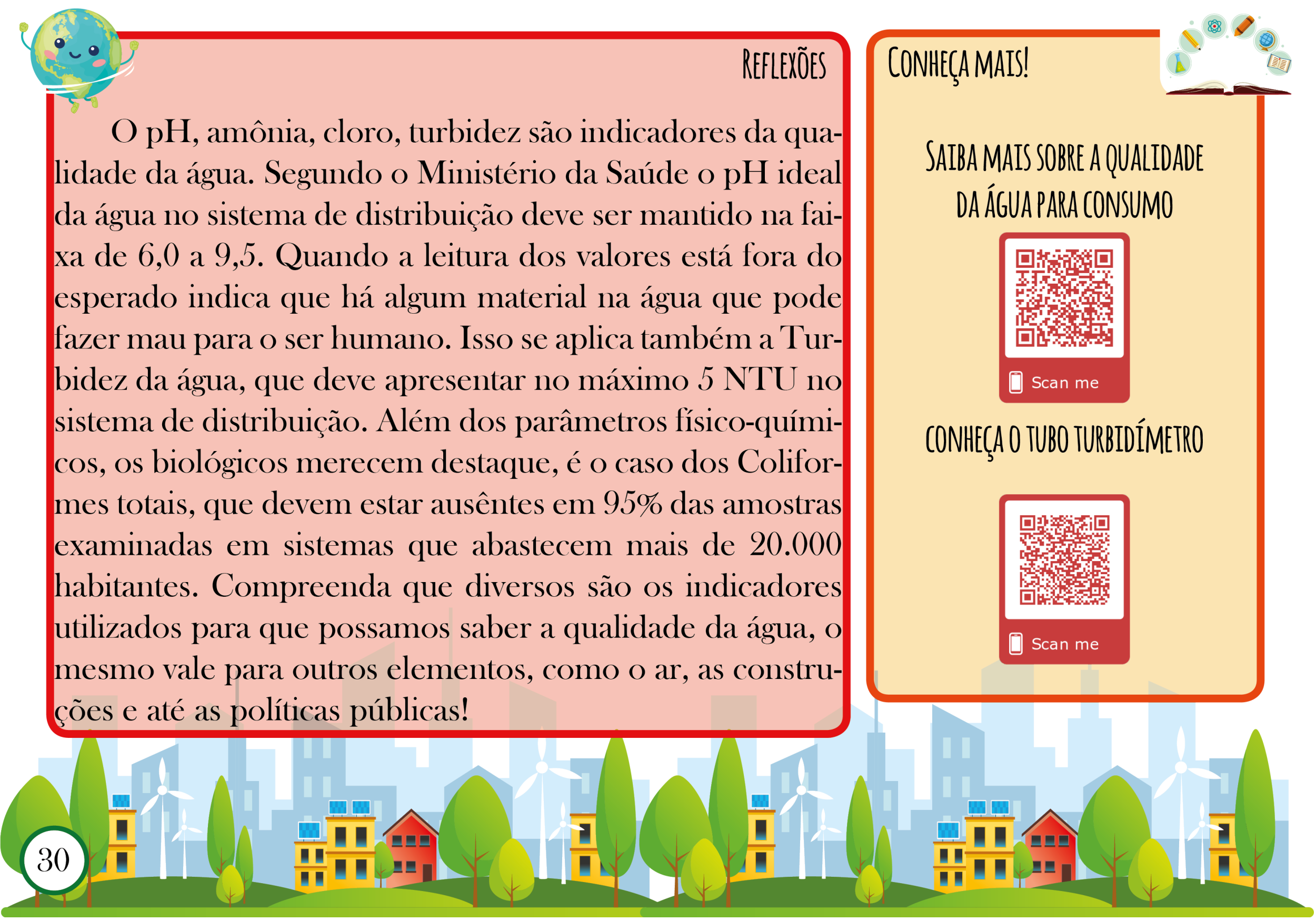




\section{CONSTRUINDO OS INDICADORES DEDESENVOLIIMENTO SUSTENTÁVEL}

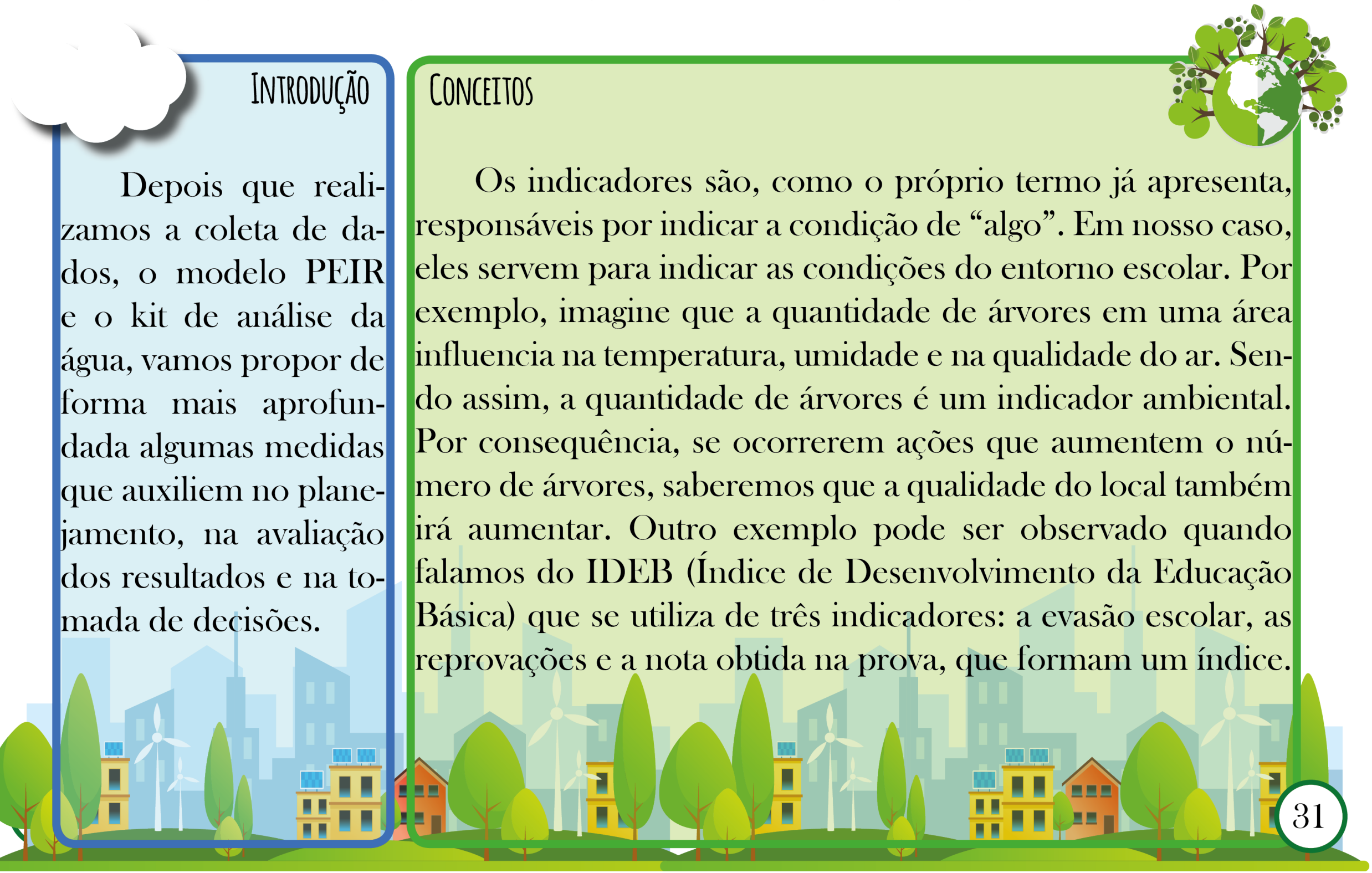




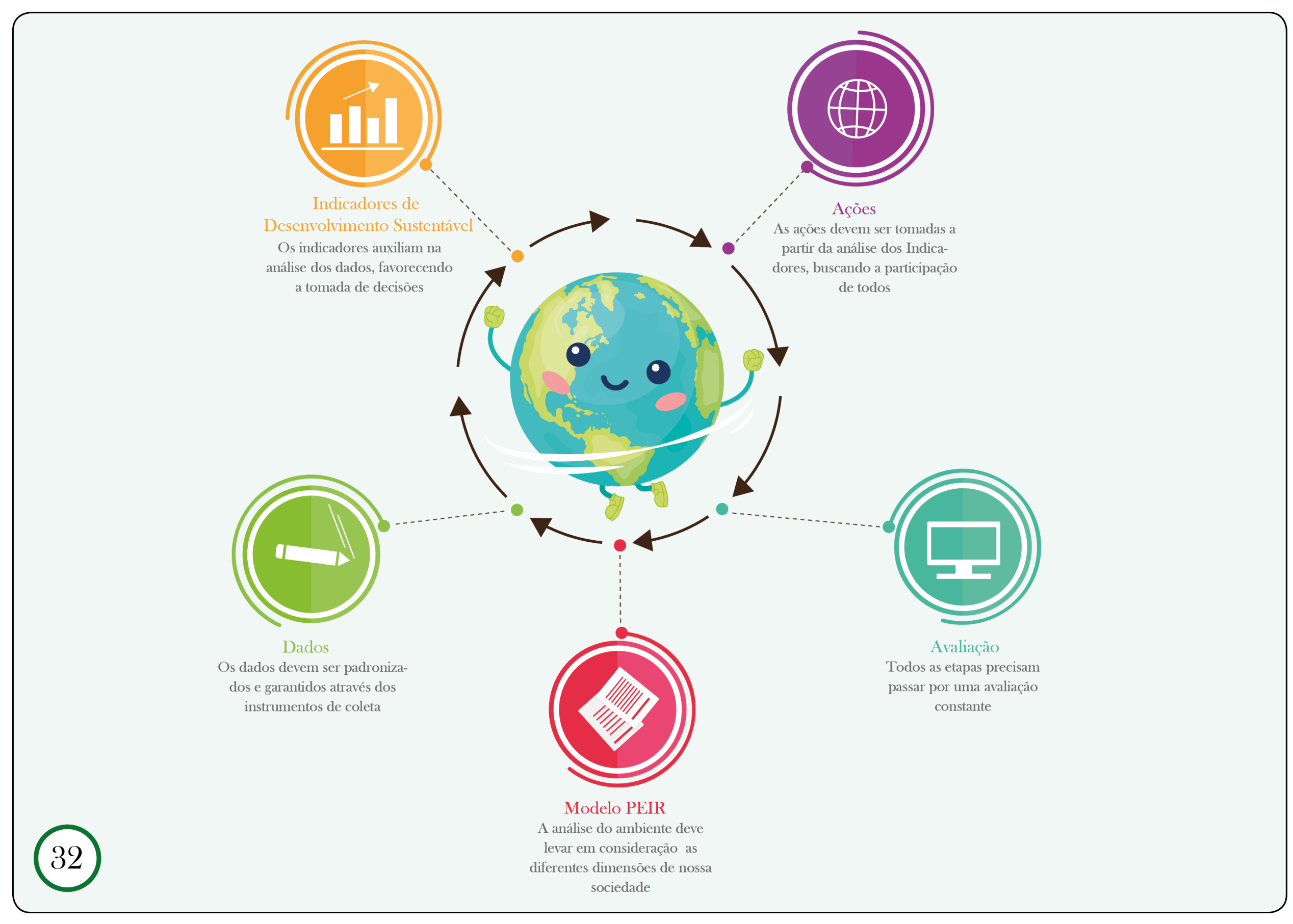


Retorne ao quadro que você fez sobre o modelo PEIR, vamos pensar em quais poderiam ser os indicadores dos elementos que você apontou. Lembre-se que eles devem auxiliar na identificação da situação em que o elemento está.

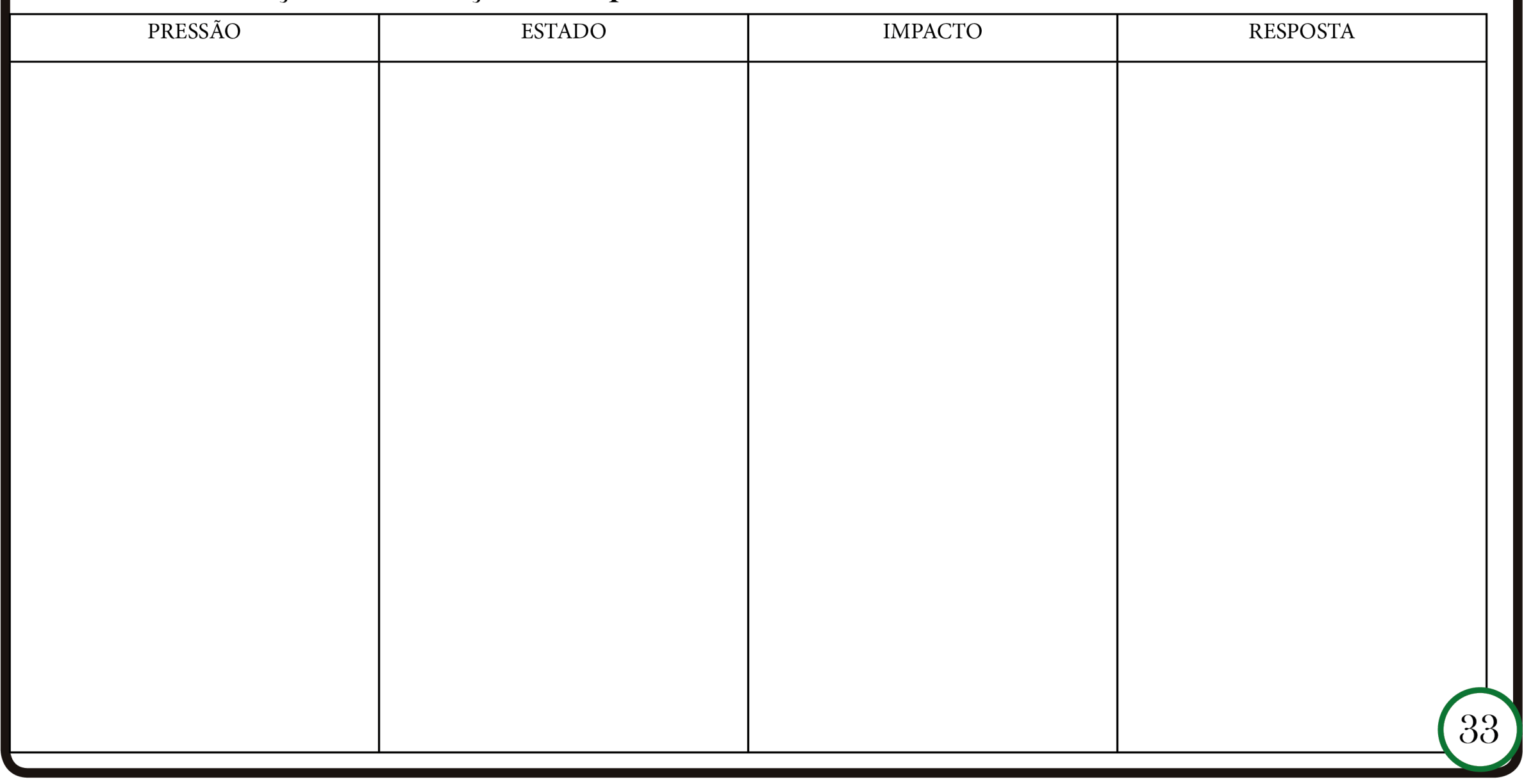




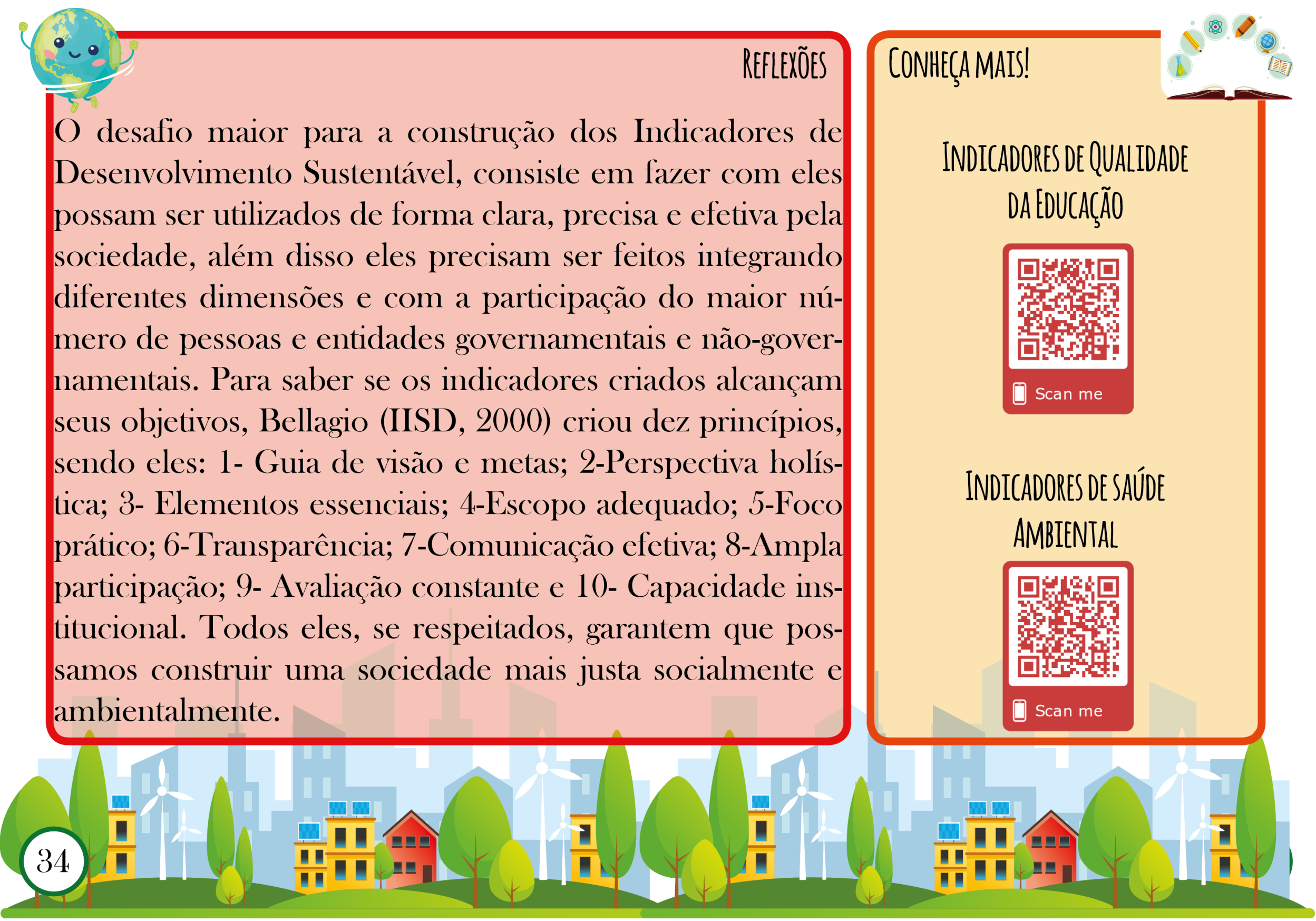




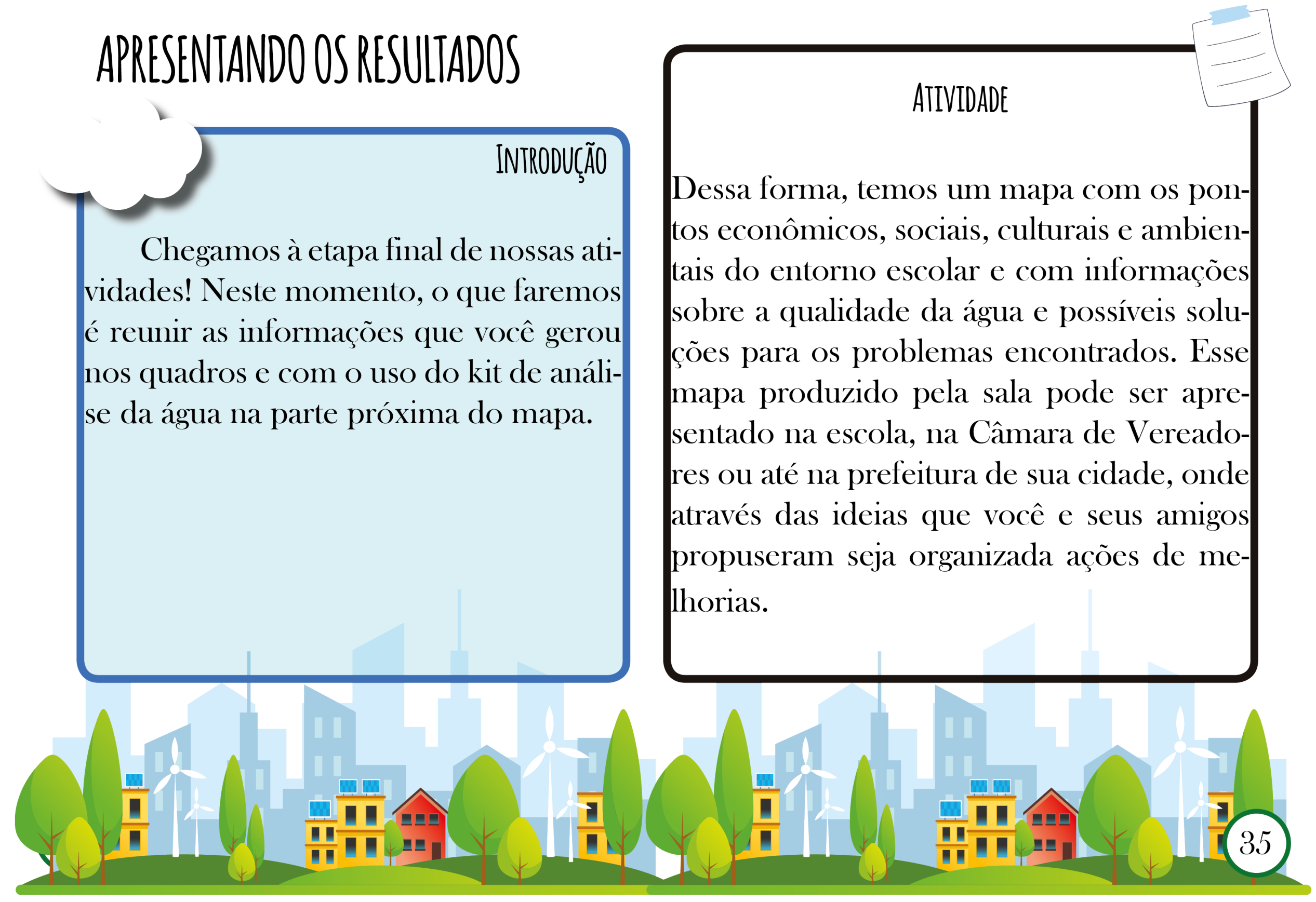




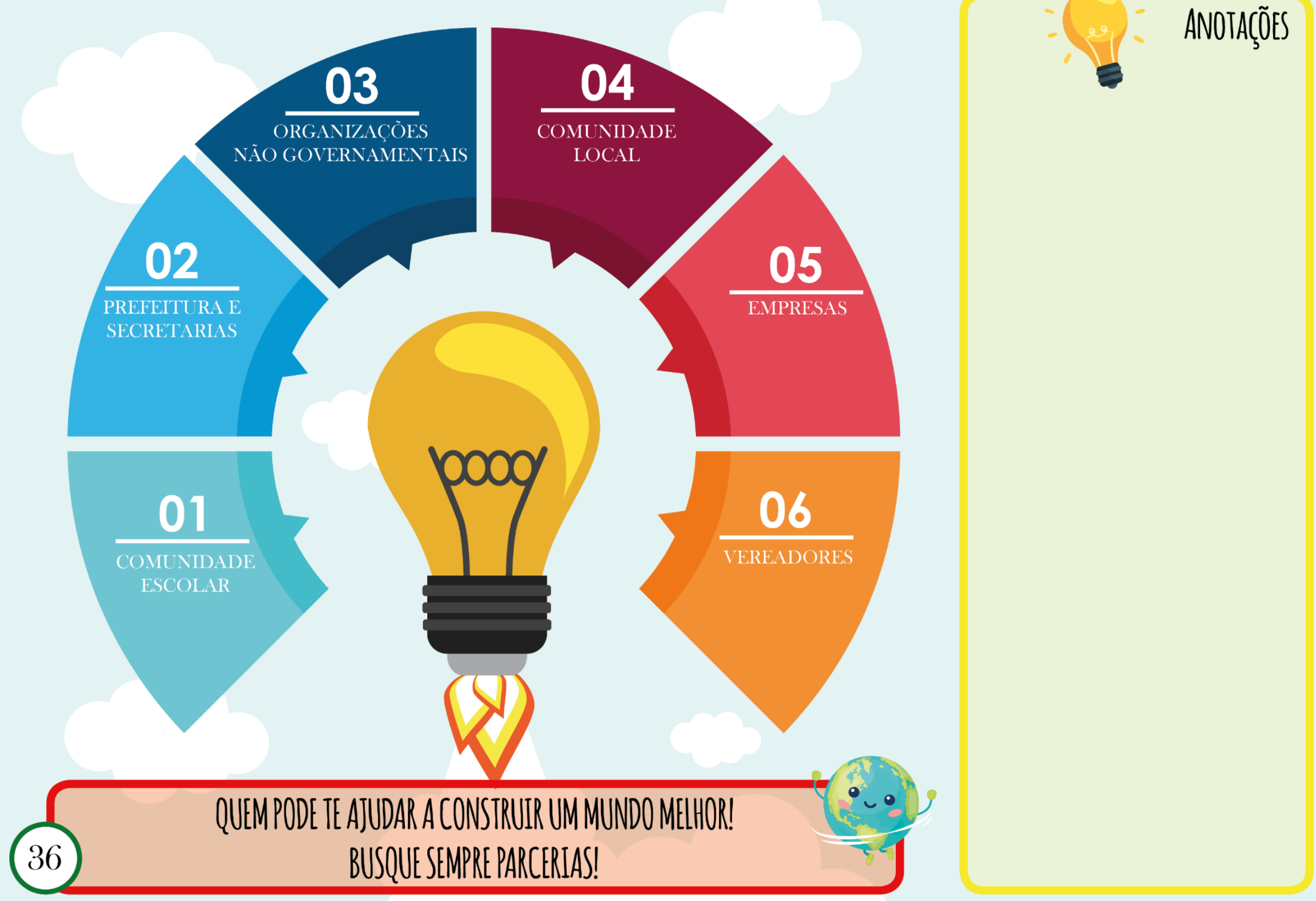




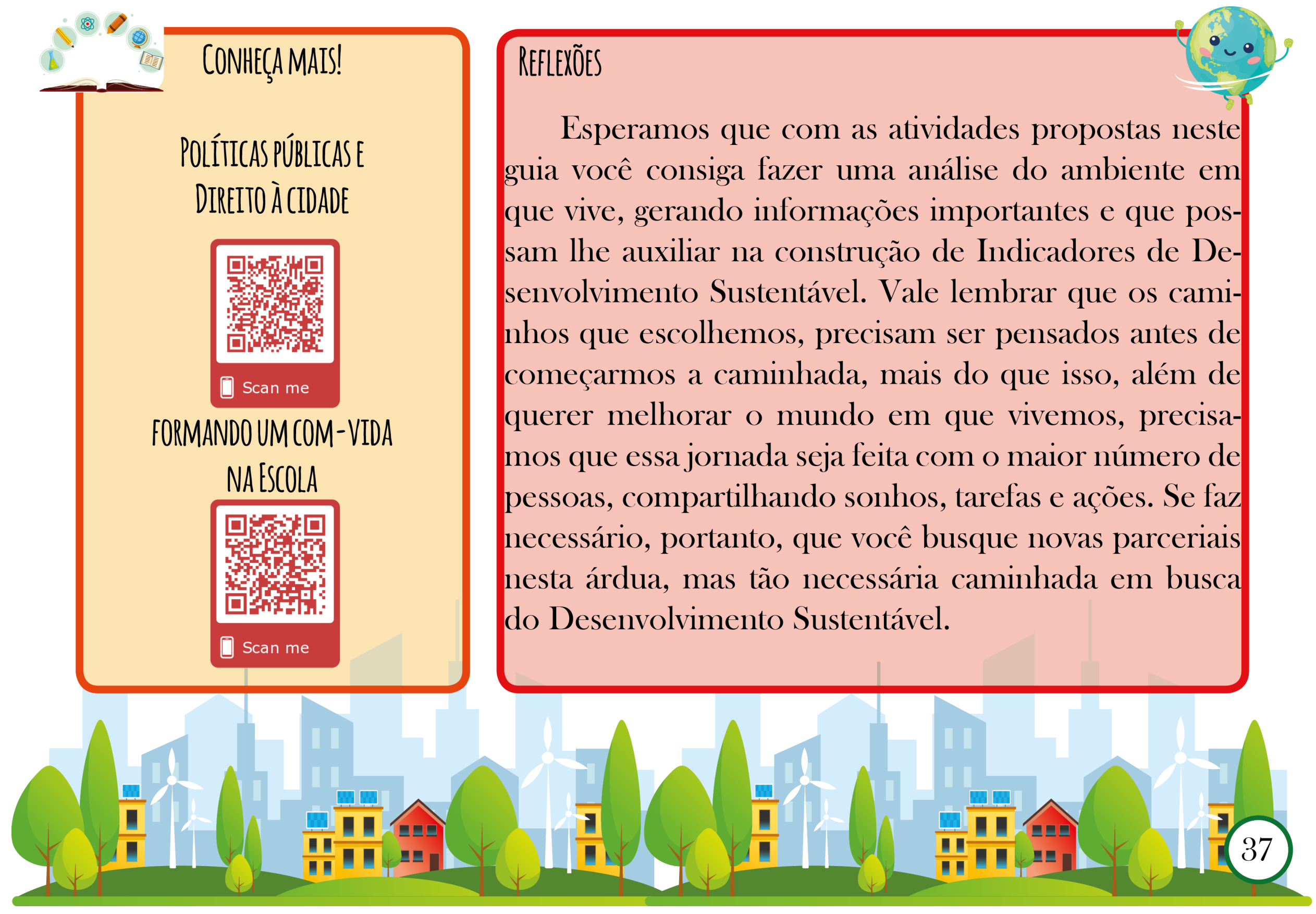




\section{ReFrêENCIAS BibiLGRŔFICAS}

ACÃO EDUCATIVA et al. Indicadores da qualidade na educação. São Paulo: Ação Educativa, 2004.

ORLANDO A. S. J. (orgs) et al. Políticas públicas e direito à cidade: programa interdisciplinar de formação de agentes sociais. Rio de Janeiro: Letra Capital, 2017.

BRASIL. Agenda 21 brasileira: resultado da consulta nacional. Brasília: Ministério do Meio Ambiente, 2004.

Formando Com-Vida. Ministério da Educação. Brasília, 2007.

Portaria n. ${ }^{\circ}$ 2.914, de 12 de Dezembro de 2011. Dispõe sobre normas de potabilidade de água para o consumo humano. Ministério da Saúde. Brasília: SVS, 2011. Saúde Ambiental: Guia básico para construção de indicadores. Ministério da Saúde. Brasília, 2011.

FALCADE, D.; MANNICH, M.; COLOMBO, G. T. Turbo de turbidez para determinação de baixo custo da turbidez em corpos d'água superficiais. REGA, Porto Alegre, v.14, ed. 5, 2017.

GOOGLE. Meus mapas. Disponível em: https://www.google.com/intl/pt-BR/maps/about/mymaps/. Acesso em: 10 dez 2018.

IISD (International Institute for Sustainable Development), Bellagio Principles, Wimnipeg, IISDnet, 2000. Disponível em https://www.iisd.org/pdf/bellagio.pdf

MALheIROS, T. F.; PHILIPPI JR. A.; COUTINHO, S. M. V. Agenda 21 nacional e indicadores de desenvolvimento sustentável: contexto brasileiro. Revista Saúde e Sociedade, v.17, n.1, p. 7-20, São Paulo, 2008.

ONU. Declaração Final da Conferência das Nações Unidas sobre Desenvolvimento Sustentável (Rio +20): O futuro que queremos. Rio de Janeiro, 2012. Disponível em http://riomais20sc.ufsc.br/files/2012/07/CNUDS-vers\%C3\%A3o-portugu\%C3\%AAs-COMIT\%C3\%8A-Pronto1.pdf. Acesso em: 10 dez 2018.

TEIXEIRA, T; LAMIM-GUEDES, V. Biomapa do bairro Jardim Netinho Prado (Jaú/SP). Revista Educação Ambiental em Ação, ano XIII, n. 50, dez/2014-jan/2015. Novo Hamburgo: Rio Grande do Sul. Disponível em: 〈http://www.revistaea.org/pf.php?idartigo-1939>. Acesso em: 10 dez 2018.

\section{Sugestões de letura para oprofessor}

BAIÃO, C. F. P.; BATISTA, G. T. Avaliação de bacia hidrográfica por alunos do Ensino Fundamental: contribuições ao ensino dos recursos hídricos, Revista Ambiente \& Água, v. 11, 2016.

FAZENDA, Ivani C. A. Integração e interdisciplinaridade no Ensino Brasileiro: efetividade ou ideologia. 6ª edição. São Paulo: Loyola, 2001.

FISCARELLI, R. B. O. Material Didático: discursos e saberes. Junqueira \& Marin: Araraquara, 2008.

FLICK, U. Uma introdução à pesquisa qualitativa. Porto Alegre: Bookman, 2004.

IBAMA. GEO Brasil 2002: Perspectivas do Meio Ambiente no Brasil. Brasília: Edições IBAMA, 2002.

IBGE. Indicadores de desenvolvimento sustentável. Brasil 2015. Estudos e Pesquisas em Geociências, n.10, 352 p., Rio de Janeiro, 2015.

LEFF, E. Epistemologia Ambiental. 4 $4^{\mathrm{a}}$ edição. São Paulo: Cortez, 2007.

LIMA, G. F. da C. Crise ambiental, educação e cidadania: os desafios da sustentabilidade emancipatória. In: LOUREIRO, C. F. B.; LAYRARGUES, P. P.; CASTRO, R. S. (Orgs.) Educação ambiental: repensando o espaço da cidadania. $5^{a}$ edição. São Paulo: Cortez, 2011.

LOUREIRO, C. F. B. Educação ambiental e movimentos sociais na construção da cidadania ecológica e planetária. In: LOUREIRO, C. F. B.; LAYRARGUES, P. P.; CASTRO, R. S. (Orgs.) Educação ambiental: repensando o espaço da cidadania. $5^{a}$ edição. São Paulo: Cortez, 2011. LOUREIRO, C. F. B. Trajetórias e Fundamentos da Educação Ambiental. $4^{a}$ edição. São Paulo: Cortez, 2012. 
LUZ, F. G. Análise da utilização de material didático de ciências no ensino fundamental da rede estadual do município de Criciúma. [trabalho de conclusão de curso]. Criciúma: Universidade do Extremo Sul Catarinense, 2006. Disponível em: http://www.bib.umesc.net/biblioteca/sumario/000028/0000286F.pdf. Acesso em 30/09/2017.

MILLER JR., T. G. Ciência Ambiental. 11ª ed. São Paulo: Thomson Learning, 2007.

MIODUSKI, K. A.; FRANCISCO, A. C. Recursos tecnológicos para a sensibilização de temas da educação ambiental. Revista Educação \& Tecnologia, n. $13,2013$.

MMA. PNIA 2012: Painel Nacional de Indicadores Ambientais. Brasília: Departamento de Gestão Estratégica, 2014.

MOREIRA, M. A. Metodologias de pesquisa em ensino. São Paulo: Livraria da Física, 2011.

PHILIPPI JR. A., PELICIONI, M. C. F. Educação ambiental: desenvolvimento de cursos e projetos. São Paulo: Signus, 2002

PILETTI, C. Didática Geral. Editora Ática: São Paulo, 2004.

PNUMA. Metodologia para elaboração de relatórios GEO Cidades. México, 2004.

QUINTAS, J. S. (orgs). Pensando e praticando a educação ambiental na gestão do meio ambiente. Brasília: IBAMA, 2006.

REIS, R. T. N.; SANTOS, R. T. F.; SANTOS, M. O.; SILVA, D. L.; SALGADO, M. F. A utilização de recursos didáticos por professores do ensino fundamental em escolas municipais de Caixias-MA. 65 $5^{\underline{a}}$ Reunião Anual da Sociedade Brasileira para o Progresso da Ciência, 2013.

SATO, M. Educação Ambiental. São Carlos: RiMa, 2003.

SILVA, L. H. DE A.; ZANON, L. B. A experimentação no ensino de Ciências. In: VASCONCELOS, A. L. S.; COSTA, C. H. C.; SANTANA. J. R.; CECCATTO,

V. M. Importância da abordagem prática no Ensino de Biologia para a Formação de Professores. Trabalho de Conclusão de Curso em Licenciatura Plena em Ciências/Habilitação em Biologia/Química, Universidade Estadual do Ceará, Limoeiro do Norte, Ceará, 2002

SILVA, L. H. DE A.; ZANON, L. B. A experimentação no ensino de Ciências. In: SCHNETZLER, R. P.; ARAGÃO, R. M. R. Ensino de Ciências: fundamentos e abordagens. Piracicaba: CAPES/UNIMEP. 182 p. 2000.

SILVA, S. S. F.; SANTOS, J. G.; CÂNDIDO, G. A.; RAMALHO, A. M. C. Indicador de Sustentabilidade Pressão-Estado-Impacto-Resposta no diagnóstico do cenário sócio ambiental resultante dos resíduos sólidos urbanos em Cuité, PB. Revista de Administração, Contabilidade e Sustentabilidade, vol. 2, n. 3, p.76-93, 2012.

SOBRAL, A.; FREITAS, C. M.; GURGEL, H.; PEDROSO, M. M. Modelos de organização e análise dos indicadores. In: Saúde ambiental: guia básico para construção de indicadores. Ministério da Saúde: BRASIL, 2011.

SORRENTINO, M. Desenvolvimento sustentável e participação: algumas reflexões em voz alta. In: LOUREIRO, C. F. B.; LAYRARGUES, P. P.; CASTRO, R. S. (Orgs.) Educação ambiental: repensando o espaço da cidadania. 5ª edição. São Paulo: Cortez, 2011.

SOUZA, S. E. O uso de recursos didáticos no ensino escolar. In: I ENCONTRO DE PESQUISA EM EDUCAÇAO, IV JORNADA DE PRÁTICA DE ENSINO, XIII SEMANA DE PEDAGOGIA DA UEM: "INFANCIA E PRATICAS EDUCATIVAS”. Maringá, 2007.

VEIGA, J. E. Indicadores de sustentabilidade. Revista Estudos Avançados. São Paulo: 2010

VIVEIRO, A. A.; DINIZ, R. E. S. Atividades de campo no ensino das ciências e na educação ambiental: refletindo sobre as potencialidades desta estratégia na prática escolar. Revista Ciência em Tela, vol. 2, n.1, 2009.

VIVEIRO, A. A. Atividade de campo no ensino de ciências: investigando concepções e práticas de um grupo de professores. [dissertação]. Bauru: Universidade Estadual Paulista, 2006.

ZANON, D. A. V; FREITAS, D. A aula de ciências nas séries iniciais do ensino fundamental: ações que favorecem a sua aprendizagem. Ciências \& Cognição; Ano 04, vol. 10, p. 93-103, 2007. 


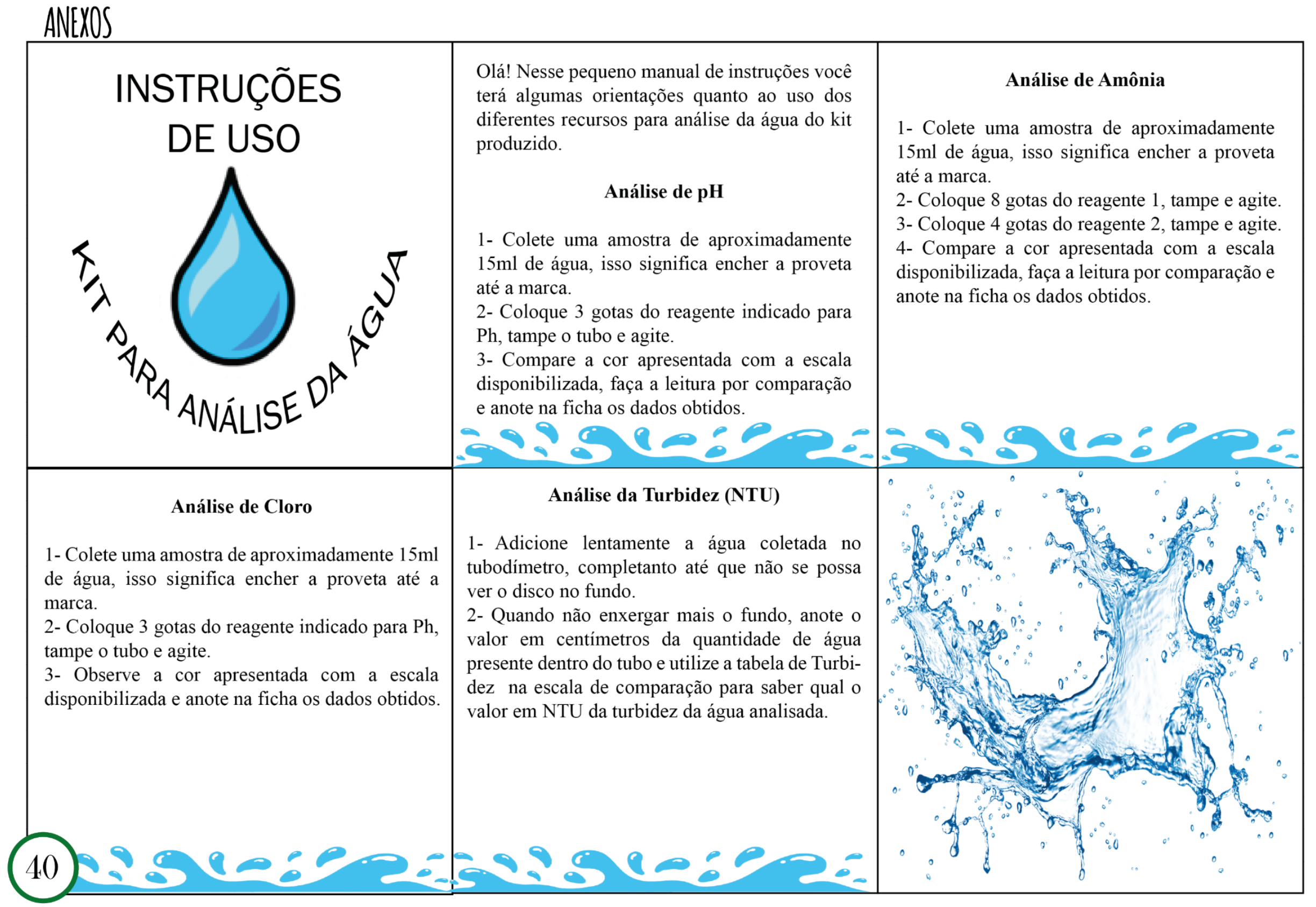




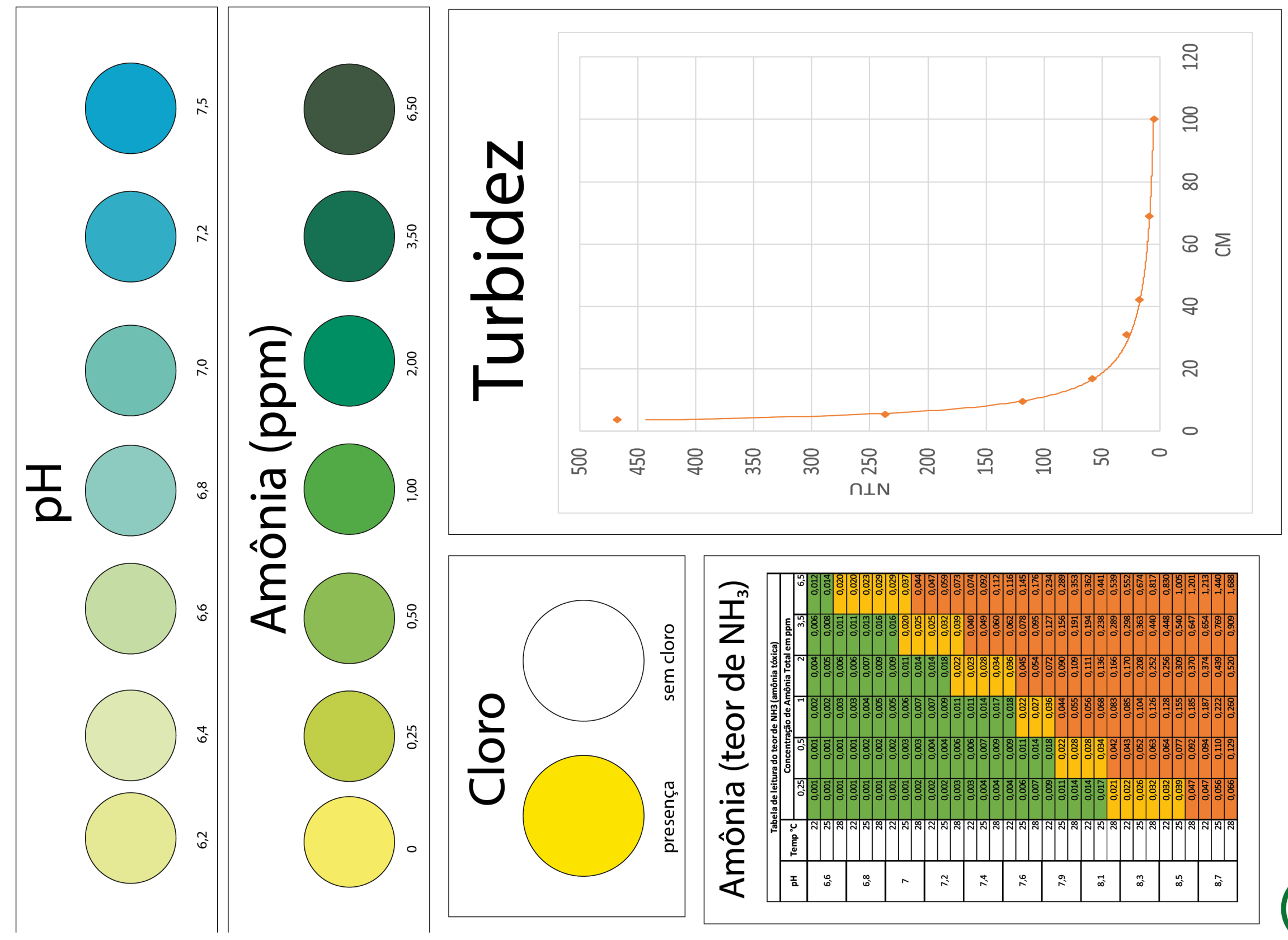

(11) 


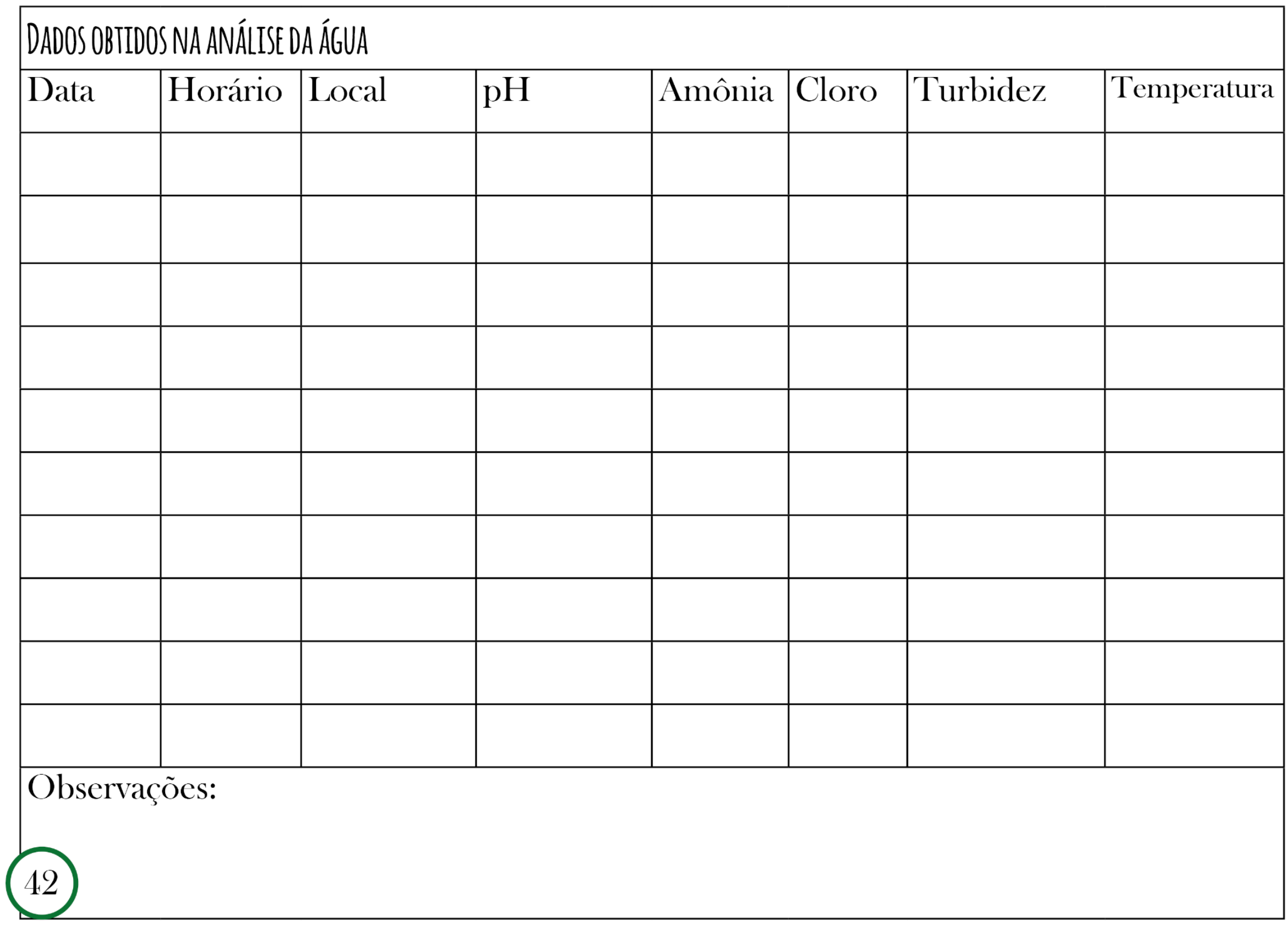


LEGENDAS DO MAPA
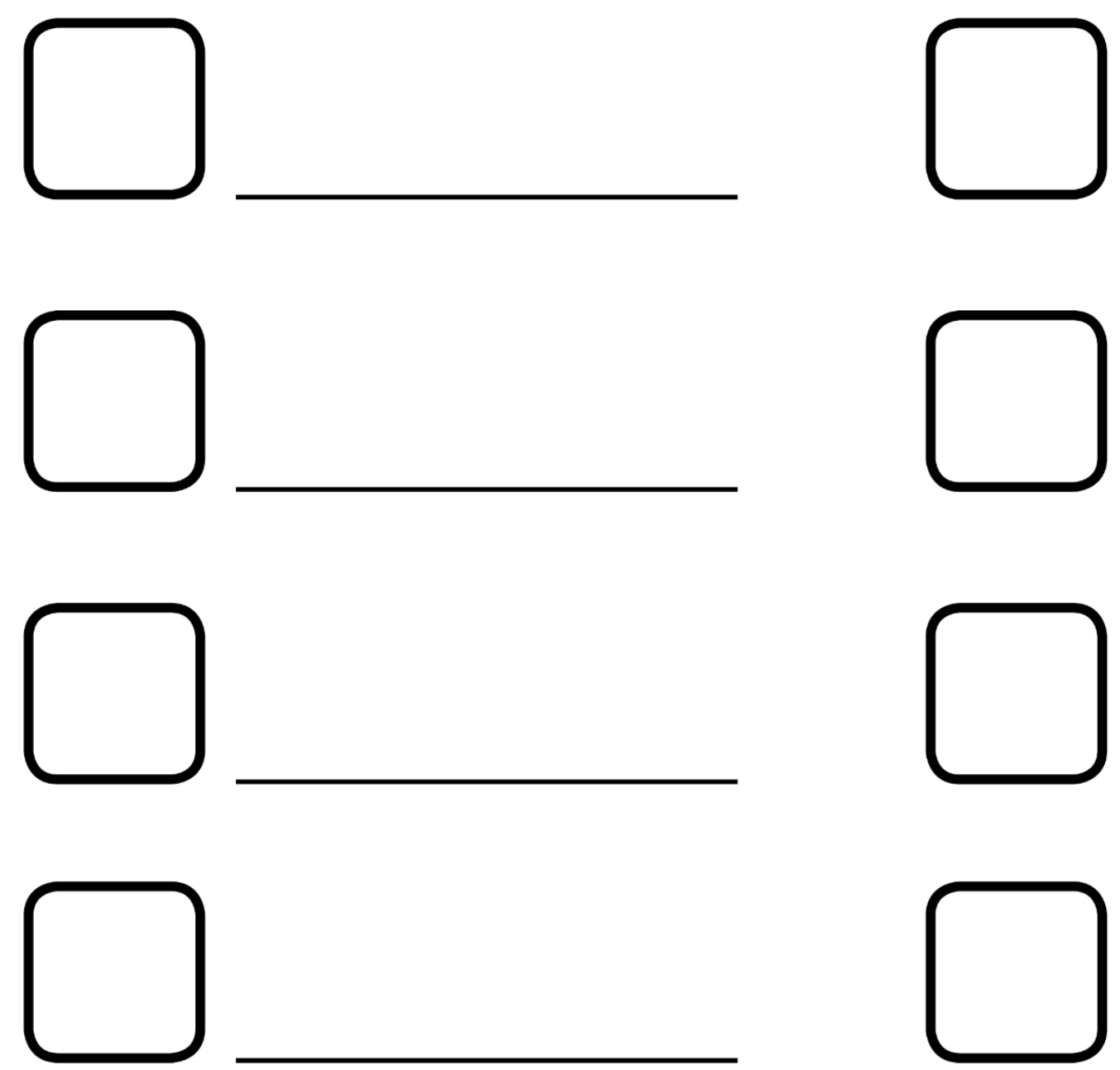
